\title{
The Role Political Connections Play in Access to Finance: Evidence from Cross-Listing
}

\author{
Brian Kelleher Richter \\ This Version: October 1, 2010
}

\begin{abstract}
What role does political influence play in access to finance? Using a comprehensive crosscountry dataset, I characterize how and why domestic political connections affect firms' ability to access all types of finance-exploiting firms' cross-listing activity as a source of empirical identification. The results extend our understanding from recent single-country studies focused exclusively on domestic bank finance. First, political influence improves firms' access to finance beyond domestic (bank) debt markets-political connections also improve access to foreign, equity finance. Second, the mechanism through which political influence works to improve access to finance is broader than political coercion of local bankers-political connections function as a firm-level substitute for strong national property rights, reducing connected firms risk premiums vis-à-vis unconnected peers.
\end{abstract}

Keywords: Cross-listing, Political Connections, Property Rights, Corporate Governance

JEL Codes: G3, D7, G15, K0, F2, O16

\footnotetext{
* Brian Kelleher Richter, Assistant Professor of Business, Economics, and Public Policy, Richard Ivey School of Business, University of Western Ontario, 1151 Richmond Street North, London, ON N6A3K7, CANADA. Office: +1 (519) 661-8326. E-mail: brichter@,ivey.uwo.ca

** This paper is represents part of my doctoral dissertation work at the UCLA Anderson School of Management. I am incredibly grateful to Mara Faccio for sharing her political connections data with me; this project would not be possible without it. Conversations with and comments from the following people have improved the research: Bruce Carlin, Bhagwan Chowdry, Mihir Desai, Felix Oberholzer-Gee, Andrew Karolyi, Amir Licht, Krislert . Samphantharak, Avanidhar Subrahmanyam, René Stulz, and Bernard Yeung. Others who had useful suggestions include: John de Figueiredo, Ed Leamer, Daniel Treisman, Romain Wacziarg, Jason Snyder, Sebastian Edwards, Mauro Guillen, Witold Henisz, and Erik Snowberg. Earlier versions of this paper were presented at UCLA Anderson's Finance Brown Bag, the 2010 UVA Darden International Finance Conference, the $2^{\text {nd }}$ International Conference on Corporate Governance in Emerging Markets, Erasmus University's Political Economy Conference, at the $19^{\text {th }}$ Annual American Law \& Economics Association (ALEA) Conference, at the $13^{\text {th }}$ International Society of New Institutional Economists (ISNIE) Conference, and the $9^{\text {th }}$ Annual Strategy \& Business Environment Conference. Seminar presentation included those at the Wharton School at the University of Pennsylvania, the Ross School at the University of Michigan, National University of Singapore's Business School, the Ivey School at the University of Western Ontario, George Mason University, ESMT in Berlin, and Royal Holloway, University of London. I am also indebted to the Center for International Business Education and Research (CIBER) at UCLA for financial support. Any mistakes are my own.
} 


\section{Introduction}

Consider two otherwise identical firms — one with political influence and one without. Will these two firms have the same access to finance? Most observers would expect a politically connected firm to have better financing opportunities than an unconnected one; the answers to why and how financing opportunities differ are less obvious - and are unresolved empirical questions I tackle in this paper.

There are at least two ways to model why maintaining a political connection improves a firm's access to finance: 1) politicians could pressure local bankers into offering better terms to favored firms; or, 2) politicians could work within their institutional environment to reduce favored firms' risk premium. Which strategic political maneuver-manipulating capital markets or providing firm-specific benefits enabled by a weak national property rights environmentbenefits firms more and which tactic is more prevalent around the world?

As for how political connections improve access to finance, firms can finance themselves using a variety of sources: debt or equity; domestic or foreign. Does corporate political influence enable preferential access to just one source of finance (e.g. domestic debt) or does the influence mechanism apply more broadly to enable preferential access to multiple sources of finance?

The purpose of this paper is to improve our understanding of how and why political economy factors influence firms' access to finance. I make three methodological contributions to this growing interdisciplinary literature by: (i) using cross-listing for empirical identification purposes; (ii) being the first to conduct a cross-country study with firm-level data; and (iii) being the first to interact firm and country factors in the analysis. I also make two contributions that advance our understanding of the complex topic, as I am the first to show: (i) that political connections improve firms' access to sources of finance other than domestic (bank) debt finance, including their access to both foreign and equity sources of finance; and (ii) that the primary mechanism driving superior access to finance is not political pressure on domestic bank employees, but rather a rational response by financiers who observe that politically connected firms should have lower risk-premiums than unconnected firms because firm-level political 
influence reduces uncertainty by substituting for a functioning national property rights regime.

\subsection{Updating our Understanding of How and Why \\ Political Economy Factors Influence Access to Finance}

Existing research into the role political influence plays in access to finance narrowly focuses on domestic debt finance in single country studies of weak institutional environments (e.g. Khwaja and Mian 2005; Claessens et al. 2008; Cull and Xu 2005; etc.). ${ }^{1}$ This research address the impunity that we know little about the role political influence plays in access to other types of finance and in other types of institutional environments. Following Dinç (2005) and Khwaja and Mian (2005), a consensus is building to suggest that the primary reason connected firms have superior access to finance is because "politically powerful firms obtain rents from government banks by exercising their political influence on bank employees." If this predominant view about political influence working on domestic bankers through a gun-to-thehead or a quid-pro-quo mechanism were to hold, then we would expect politically connected firms to eschew both foreign finance and equity finance at least relative to their unconnected counterparts: connected firms should favor the cheaper bank debt that affiliated politicians purportedly provide. Following this logic, we should expect that connected firms especially forgo foreign equity financing; however, empirically we observe this is not the case.

I show that firms with domestic political connections are more likely than their unconnected counterparts to globalize their financing through cross-listing equity securities on markets outside their home countries. Moreover, the effect of political connections is strongest ceteris paribus for firms whose home country has weak property rights - a factor that normally decreases access to finance because it increases firms' risk premiums - suggesting the prevailing mechanism has little to do with coercion of bank employees, but rather that the mechanism has more to do with firm-level political connections functioning as a substitute for strong national property rights, thereby reducing privileged firms' risk premiums and improving access to

\footnotetext{
${ }^{1}$ Those single-country studies cover: Brazil (Claessens et al. 2008), China (Cull and Xu 2005; Li et al. 2008), Indonesia (Leuz and Oberholzer-Gee 2006), Pakistan (Khwaja and Mian 2005), the Philippines (Hutchcroft 1998), Malaysia (Johnson and Mitton 2003), Thailand (Charumilind et al. 2006), South Korea (Kang 2002), and Vietnam (Malesky and Taussig 2009).
} 
capital. $^{2}$ Further support for the new mechanism I identify (lower risk premiums for connected firms especially in weak property rights environments) comes when I refute alternative mechanisms (suggested in single-country studies on the role political influence plays in access to finance) by showing that there is no significant effect on access to foreign finance when firms' political connections are interacted with: (i) governments' ownership stakes in domestic banks, (ii) weak contracting institutions, or (iii) measures of national cultures of corruption.

\subsection{Methodological Improvements over Related Studies}

While the connection between firms' cross-listing activity and firms' political connections that this article explores in its empirical tests might not seem readily apparent, it was intentionally chosen to improve empirical identification while getting at the broader questions of how and why political economy factors affect firms' access to all types of finance. Firms' crosslisting decisions provide a particularly attractive setting in which to identify empirically and characterize the means through which domestic political connections create value in accessing finance. Studying cross-listing, instead of domestic loans, overcomes several weaknesses in existing research designs on political influence and access to finance by: (i) reducing typical endogeneity concerns; (ii) allowing for cross-country tests that enhance external validity; (iii) fully controlling for country-level factors in the data; and (iv) using observable country-level factors to test alternative hypotheses about mechanisms that could explain connected firms' superior access to finance.

Examining firms' ability to access foreign capital through cross-listing helps free my study from the endogeneity concerns that typically plague studies of the role political influence plays in improving access to, and the terms on, domestic bank loans. Politicians could readily manipulate local bankers into offering financing arrangements they would not otherwise given government ownership and regulation of domestic banks (La Porta et al. 2002; Dinç 2005). Consequently, studies focused on domestic debt need to overcome concerns about firms

\footnotetext{
${ }^{2}$ A simple explanation for the result is that it is more valuable for politically connected firms to secure firm-specific property rights over the long run than it is to receive preferential loans only during the short run associated politicians hold office and can pressure bankers; this is also consistent with firms recognizing the contingent value of political capital they hold. (Seigel 2007)
} 
choosing to become politically connected explicitly so that politicians will manipulate domestic bankers' loan decisions on their behalf. This concern is not salient, however, when we examine firms' choice to cross-list securities. Equity markets are difficult for politicians to manipulate because of participants' dispersed nature (Rajan and Zingales 2003). Foreign securities-investors are also difficult for local politicians to manipulate, particularly when they do not have a local presence where they invest. Domestic bankers have incentives to do as politicians say, but foreign investors and equity market participants have little incentive to bend to other countries' politicians' whims. ${ }^{3}$

In addition to providing a unique identification strategy, another advantage of using cross-listing as my dependent variable is that the data is available across countries. Past studies on political influence and finance leave doubts about their external validity because insufficient cross-country data on firms' political influence and on bank loan portfolios limited them to single country cases. ${ }^{4}$ Besides enhancing my study's external validity, cross-country data also allow me to characterize which country-level attributes shape the value of firm-level political connections in obtaining access to finance by exploring their interaction terms in my regressions. Single-country studies cannot explore these interactions because there is no variability in country-level characteristics, such as cultures of corruption, state ownership of banks, or property rights institutions. The technique of exploring interactions between firm level characteristics and country-level factors is an innovation in the broader literature on corporate political influence enabled by the cross-country nature of this study.

\subsection{A Simple Example}

Italy's Mediaset S.p.A. provides the prototypical example of a politically connected firm that receives favorable financing terms (and cross-lists securities) because its politician-owner can use his power to craft measures that support his enterprise in a moderately-weak property rights environment. Italy's Prime Minister Silvio Berlusconi founded the firm and remains its

\footnotetext{
${ }^{3}$ For example, an English banker faces little serious consequence if he does not do what a Malaysian politician says; however, a local Malaysian banker could face serious consequences for ignoring the same politicians' pleas.

${ }^{4}$ Data on domestic bank loan portfolios are not widely available across countries because they are proprietary. Furthermore, finding a standardized metric of political influence across countries is difficult; Faccio's (2006) data creates an exception.
} 
largest investor (with an ownership stake near 30\%). Rather than wielding his power to coerce the largest domestic banks (in which the government maintains a 35\% stake) to make him loans on favorable terms while in office, Berlusconi concentrated on passing legislation that protected his television and media enterprises' content from piracy. The legislation created a more stable long-run operating environment for Mediaset as it provided Berlusconi’s firm enhanced legal recourse against violators of his firms' intellectual property. ${ }^{5}$ Financiers, including ones in foreign capital markets, chose to reward this corporate political strategy. The strategic benefits of focusing on securing long-lasting property rights specific to Berlusconi's media enterprises clearly dominated what the benefits would have been if the Prime Minister had coerced government-owned banks to offer him preferential financing only during his periods in office.

\subsection{Structure of Paper}

The paper is structured as follows. Section 2 integrates a review of closely related literature into the analytic framework I will use. ${ }^{6}$ Section 3 describes the data. Section 4 applies the data to empirical tests of my three main propositions. Section 5 contains a discussion of how the empirical results require us to update our thinking about the strategic role political connections play in firms receiving preferential access to finance. Section 6 concludes.

\section{Analytic Framework and Related Literature}

An integrated analysis of the political economy determinants of firms' access to finance, including cross-listing, should simultaneously consider the roles of both firm-level and countrylevel factors. The independent roles of domestic firm-level political connections and domestic country-level institutions are the subject of the first two propositions I present. These first two propositions build towards the third, in which I propose a way to reconcile independent roles of firm- and country-level variables.

\subsection{The Role of Domestic Political Connections}

Firms' political connections have a market value (Fisman 2001). Political influence

\footnotetext{
${ }_{6}^{5}$ For example, the Urbani Decree was among several pieces of legislation aimed at protecting copyrighted media content. ${ }^{6}$ A more comprehensive literature review_-on cross-listing, institutions, and corporate political influence-is in an Appendix.
} 
enables firms to receive preferential access to domestic debt finance, potentially because politicians meddle with local bankers (Khwaja and Mian 2005; Cull and Xu 2005; Claessens et al. 2008). Domestic debt, however, is only one source of finance used by large firms; foreign and equity finance are alternative sources. Firms frequently finance abroad through cross-listing equity securities (Karolyi 2006). ${ }^{7}$ We do not know, however, if the mechanism through which political influence works also wins firms superior access to foreign equity finance. This leads to the first relationship, I test:

\section{Proposition 1: Cross-listing (access to any source of finance) is more likely} if a firm has domestic political connections.

Existing empirical tests of the role domestic political connections play in cross-listing generates mixed evidence in single-country studies: Hung et al. (2008) find a positive effect using data from China, ${ }^{8}$ while Leuz and Oberholzer-Gee (2006) and Siegel (2009) find a negative effect using data from Indonesia and Mexico, respectively. ${ }^{9}$ No one has yet run the cross-country test necessary to resolve the debate by showing whether political influence has a positive or negative effect on cross-listing across countries.

Consistent with mixed empirical evidence from the single-country studies, there are theoretical reasons to expect either result. On one hand, if Khwaja and Mian's (2005) story about a mechanism in which domestic bankers are susceptible to gun-to-the-head or quid-quopro political tactics holds for large firms across countries, then we would expect to find a negative effect of firms' domestic political connections on their propensities to cross-list since these firms should favor cheaper domestic debt to foreign equity. ${ }^{10}$ On the other hand, if the

\footnotetext{
${ }^{7}$ In 2004, more than $20 \%$ of the firms listed on the New York Stock Exchange were foreign as was over $50 \%$ of the value traded on the London Stock Exchange (Karolyi 2006). Firms cross-list when the benefits, including a reduction in the firm's cost of capital (Hail and Leuz 2009), exceed the costs. For a more in-depth literature review on cross-listing see the Web Appendix. ${ }^{8} \mathrm{Hung}$ et al. (2008) argue that the reason they find firms with domestic political connections in China are more likely to cross-list is that the action dramatically improves corporate governance; this result is consistent with the benefits of the regulatory bonding theory of cross-listing promulgated by Coffee (1999) and Stulz (1999).

${ }^{9}$ Leuz and Oberholzer-Gee (2006) claim political connections are substitutes for foreign financing in Indonesia because they provide firms a better domestic financing alternative: government coercion of bankers. Siegel (2004) argues that firms with political connections have less need to cross-list because connections are a reputational bond valuable mainly for domestic credit.

${ }^{10}$ If firms' weighted average cost of capital is determined in a general equilibrium setting, foreign equity financiers should charge a higher rate to fund politically connected firms that they suspect of receiving some fraction of their domestic debt at below market rates by virtue of politicians' domestic capital market manipulation. Charging firms that finance themselves using political coercion higher rates would help restore the equilibrium terms and compensate financiers for the additional risk.
} 
mechanism through which political influence works is broader and applies to accessing all sources of capital, then we would expect to find a positive effect of firms' domestic political connections on their propensities to cross-list.

Several researchers, in the growing literature on the outcomes firms obtain through political influence, document ways firms benefit other than through coercion of local bankers, including: allocating rights to scarce resources (such as TV or radio frequencies), helping firms secure favorable regulation (Agrawal and Knoeber 2001), winning firm-specific tax breaks (Richter et al. 2009), ensuring that entities win government appropriations (Roberts 1990; de Figueiredo and Silverman 2006; Goldman, Rocholl, and So 2008), and being more likely to be bailed out in times of financial distress (Faccio, Masulis, and McConnell 2006). To the extent that these benefits (obtained by manipulating the property rights system) stabilize firms' operations over the long run, they should reduce firms' risk premiums - in which case, financiers, both domestic and foreign, would rationally choose to offer connected firms better financing terms, irrespective of political pleas.

\subsection{The Role of Domestic Economic Institutions}

In addition to firm-level political economy factors, country-level political economy factors also shape firms' access to finance. Domestic economic institutions define country-level "rules of the game" (North 1981) and are typically "unbundled" into property rights and contracting varieties for analytic tractability (Acemoglu and Johnson 2005). They shape economic outcomes at the country-level (Acemoglu et al. 2005; La Porta et al. 1998) and at the firm-level (Laeven and Woodruff 2007). Accounting disclosures, as a type of contracting institution, play a prominent role in past inquiry into the determinants of cross-listing as a source of finance (e.g. Coffee 1999, 2002; Stulz 1999; Doidge et al. 2004); however, countries' economic institutions are multidimensional. Other aspects of countries' institutions, most notably their property rights, have received no empirical attention in determining firms' propensities to cross-list as a source of finance. This leads to the second relationship I test:

Proposition 2: Cross-listing is more likely if firms' home-country economic institutions are stronger, for both property rights and contracting. 
The key difference between the regulatory bonding hypothesis ${ }^{11}$ of cross-listing and my Proposition2 is that mine recognizes that several different components of countries' institutional environment affect whether or not firms cross-list, not just the quality of contracting institutions. Tests of the regulatory bonding hypothesis support part of my Proposition 2 by finding that cross-listing is more likely the higher the quality of domestic accounting disclosures (e.g. Doidge et al. 2004); ${ }^{12}$ however, no one has tested the other part of Proposition 2, whether cross-listing is more likely the stronger domestic property rights are.

What the cross-listing literature conjectures about the role of property rights, but does not test, is consistent Proposition 2. Regulatory bonding proponents such as Stulz (2005) argue that weak property rights reduce firms' cross-listing activity because "financial globalization reduces the state's [and other's] ability to expropriate."Regulatory bonding skeptics strike a similar chord: Siegel (2005) suggests that stronger domestic property rights may improve firms' access to foreign finance since cross-listings alone "are far from a perfect substitute for ... preventing fraud, theft, embezzlement, and asset taking."

Furthermore, foreign financiers operating in major capital markets may not have a strong appetite for investing in firms from weak property rights countries (Stulz 2005). The relative unpredictability of firms' cash flows in those environments may scare away money-center investors. Domestic financiers may have a comparative advantage in understanding the exact risks weak property rights pose for particular firms - making domestic financiers more willing to extend capital to the average firm in those environments on more favorable terms than foreign financiers, since they can better evaluate the risk premium given local information advantages (Coval and Moskowitz 1999).

\footnotetext{
${ }^{11}$ Coffee $(1999,2002)$ and Stulz (1999) were early proponents of a regulatory bonding hypothesis explaining why some firms cross-list; Doidge et al. (2004) were the first to formalize the regulatory bonding hypothesis, building a mathematical model. The hypothesis states that firms cross-list because they benefit from functionally, and credibly, converging towards having the higher quality contracting institutions (or disclosure requirements) of their cross-listing destination, while maintaining operations in their traditional home; the larger the gap between contracting institutions in a firms' home country and in its cross-listing destination, the greater the costs and the greater the potential benefits (Doidge et al. 2004).

${ }^{12}$ Support for the regulatory bonding hypothesis is found by Doidge et al. (2004), Lel and Miller (2008), and Doidge et al. (2009) among others. Doubts about the regulatory bonding hypothesis are cast by Licht (2003), Siegel (2005), and Lang et al. (2006); however, none of these authors refute the empirical finding that higher quality domestic accounting enables firms to cross-list.
} 


\subsection{Domestic Political Connections in the Context of Economic Institutions}

All firms are embedded in the "rules" that domestic economic institutions dictate. Some firms are (politically) connected to the institutional stewards (or governments) who both set and enforce the rules, while other firms are not. Hence, domestic political connections could functionally enable firms to operate as though they were in a stronger institutional environment (Xin and Pearce 1996). Even North (1990) acknowledges the importance of political interactions in reducing agents uncertainty when economic institutions cannot, noting that heterogeneity exists in how firms experience institutions.

Depending upon the institutional context, politicians may have greater or less control over the variability between formal property rights institutions and the informal support they can offer to favored firms. Governments in the weakest environments are likely to have the greatest ability to manipulate the implicit rules because their explicit rules are further from the ideal (found in strong institutional environments, in which only the most competitive firms would win government allocated property rights and in which taxation was non-distortionary). Hence, in weak institutional environments political actors can create relatively larger opportunities for some firms using their powers to selectively grant or enforce property rights or to otherwise improve outcomes for privileged firms.

Given that political influence can help mitigate institutional weaknesses, it is important to consider a key difference between contracting institutions and property rights institutions: all firms can improve their contracting environment by voluntarily adopting stricter accounting standards (Bradshaw et al. 2004), but only the few firms privileged enough to be politically connected can improve their firm-specific domestic property rights environment. This leads to the third, relationship I test:

Proposition 3: Cross-listing is more likely for firms with domestic political connections
when home-country property rights institutions are weak.

The possibility that firms with political connections experience national institutions differently than firms without political connections has yet to be explored in any cross-country empirical test. Past inquiry into the political economy determinants of cross-listing has 
considered the independent roles of domestic firm-level political connections or of some aspects of country-level institutions, but it has not considered how they interact - that is, whether they work as substitutes or complements. I do, which leads to a substantive contribution to our understanding of the political economy of firms' access to finance.

If political connections create tacit domestic property rights benefits for privileged firms - particularly if tacit benefits are important to all financiers including foreign ones-I should find support for Proposition 3. This is reasonable if we expect domestic governments to protect or privilege firms with which they have strong ties from the ills of a weak property rights environment better than they protect or privilege firms with which they have no ties. Furthermore, implicit domestic property rights support should reduce uncertainty in politically connected firms' domestic cash flows; these, in turn, should lower their risk premium, making them more attractive to all types of investors. Foreign investors, in particular, may have a difficult time assessing the particular risks weak domestic property rights pose to a specific firm unless the firm maintains political connections as a form of tacit support.

If, in addition to protecting politically connected firms from weak property rights environments, governments also coerce domestic banks into giving connected firms preferential financing, this would pose a challenge to Proposition 3; it would also be inconsistent with politically connected firms being more likely to cross-list as in Proposition 1.The reason past research finds that domestic banks extend favorable debt financing terms to politically-connected firms could have little to do with government coercion of bankers. Firms' preferential access to all sources of finance may instead be a rational market response to the explicit signal political connections send that firms maintaining ties receive implicit property rights support.

\section{Building a Multi-level, Cross-Sectional Dataset}

To test the three propositions above - and to achieve this paper's purpose by investigating the role domestic firm-level political connections and domestic country-level institutions play in firms' cross-listing choices-I build a multi-level, cross-sectional dataset that includes firms in a variety of industries, across 46 countries. A cross-sectional setting is well 
suited for testing the propositions presented in the prior section; moreover, there is little meaningful time variation in the key independent, political economy, variables that effective panel data tests would require. ${ }^{13}$ The firms included in my sample are congruent with those in Faccio's (2006) work on political connections as well as those in Doidge et al.’s (2004) work on the value of cross-listing. ${ }^{14}$ My core sample includes 12,395 firms.

\subsection{Dependent Variable: Observed Firm-level Global Financing Decisions}

The dependent variable I will use throughout my analysis $\left(y_{i}\right)$ will be an indicator of whether or not we observe a firm maintaining a cross-listing in a securities market outside of its home country. It is a dummy variable that will be used in binary choice regressions:

$$
y_{i}=\left\{\begin{array}{l}
1, \text { if firm } i \text { lists equity securities on any market outside its home country } \\
0, \quad \text { if firm } i \text { lists equity securites domestically, but nowhere else }
\end{array}\right.
$$

My definition of cross-listing is based on Doidge et al. (2004), but expands on itby incorporating firms that cross-list on any capital market around the world rather than focusing exclusively on U.S. cross-listings. ${ }^{15}$ I only set $y_{i}=1$ if a firm actively maintains a cross-listing as of January 2003, to match the timing of the political connections data I use. When $y_{i}=0$, connected firms may finance themselves through regular domestic channels or by using political coercion of bankers, as initially suggested by Khwaja and Mian (2005), since both are observationally equivalent. ${ }^{16}$ Unconnected firms presumably cannot unduly manipulate domestic bankers' decisions.

\footnotetext{
${ }^{13}$ Acemoglu et al. (2001) assert that country-level economic institutions are highly persistent; data supports this. Likewise, political connections demonstrate little year-to-year variation; when they do it is often the result of a shocks such as unexpected election outcomes (Faccio 2006) or health surprises (Fisman 2001; Fisman et al. 2006). Furthermore, no data is available on how domestic firm-level political connections vary over time for a large cross-section of countries.

${ }^{14}$ I limit my sample to firms in both Faccio's (2006) and Doidge et al.'s (2004) core samples. Both use Worldscope, which covers $96 \%$ of the world's market capitalization; I use Datastream/Worldscope database which fully incorporates all data from earlier Worldscope and Datastream databases. Doidge et al. (2004) exclude firms in the U.S. since they are looking specifically at the value of cross-listing in the U.S. Faccio (2006) excludes firms for which data on ownership/control was unavailable on the $\mathrm{CD}$ version of Worldscope; Faccio privately shared with me the information necessary to reconstruct her original sample.

${ }^{15}$ Pagano et al. (2002) and Sarkissian and Schill (2004) suggest it is important to consider cross-listings in countries other than the U.S., despite much of the academic literature focusing on the American Depository Receipts (ADRs). As in Doidge et al. (2004), I use the Bank of New York's ADR dataset and JP Morgan's ADR.com to check if a firm is cross-listed in the U.S. For crosslistings in other countries, I use Datastream/Worldscope which provides information on all markets.

${ }^{16}$ While possible, it is unlikely that when $y_{i}=1$ a firm may also finance itself through political interference with bankers' decisions. It is unlikely because 1) rational foreign financiers would offer a firm suspected of using back-channel financing above market rate financing terms to compensate for their below market financing terms domestically, and 2) the greater disclosure required of cross-listed firms would tend to expose these arrangements and cause them to lose their value or efficacy.
} 


\subsection{Key Independent Variables}

\subsubsection{Domestic Firm-level Political Connections}

My data on domestic firm-level political connections comes from Faccio (2006).It is the most comprehensive and credible dataset on firm-level political connections across countries. ${ }^{17}$ The dummy variable, $d_{-}$connect $_{i}$, takes on a value of 1 if a firm is politically connected and a value of 0 if a firm is not connected in the year $2002 .{ }^{18}$ The measure of political connections in the Faccio dataset is a strict and objective one, constructed from directly observable criteria for all market participants. A firm is defined as politically connected only if "one of its large shareholders or top officers is a member of parliament, a minister, or is closely related to a top politician." Since the measure is a conservative one, if anything it may understate the extent of and importance of political connections (Faccio et al. 2006). ${ }^{19}$ Another advantage of this strict definition of political connections is that the connections are not the type that firms can readily "buy" or "invest in" since they are both transparent and with individuals who are in positions where they can be held accountable for particularly egregious/abusive rentseeking behavior. $^{20}$

\subsubsection{Country-level Economic Institutions}

The data I use for my key country-level independent variable, the quality of economic institutions, is consistent with Acemoglu et al. (2001) and La Porta et al. (1998). ${ }^{21}$ The variable

\footnotetext{
${ }^{17}$ The key advantage of the Faccio (2006) dataset is that it spans across countries. It is difficult to gather data on political connections across countries, making such studies rare. One of the problems with collecting data on political connections across countries is that the literature's definition of just what constitutes a connection changes depending upon context. Sometimes subjective assessments of the strength of connectedness are used as a measure (e.g. Fisman 2001). In other instances, firm's expenditures on campaign contributions or lobbying are used as a measure (e.g. Claessens et al. 2008). In yet other instances, objective directly observable behavior (such as of whether or not politicians have been or currently are employed by a given firm) are used to construct a dummy variable for political connections (e.g. Faccio 2006, or Ferguson and Voth 2008).

${ }^{18}$ It is only accurate in 2002 limiting us to cross-sectional analyses when using the data. While many firms choose to de-list in the U.S in 2002 following the Sarbanes-Oxley legislation going into effect, this is not a major concern for my analysis because most of those firms re-listed on a European exchanges included in my cross-listing measure.

${ }^{19}$ This exposes another limitation of the dataset; that it does not include links to former politicians or to current or former SOEs all of which may enjoy a privileged status but which may not be coded as being connected. To test for potential bias caused by an under-reporting of political connections, I estimated my main results on a sub-samples of the data excluding countries with no political connections and excluding countries with the most political connections and obtained largely the same results or at least ones we would predict by excluding countries with certain levels of property rights institutions. These regressions are included in Appendix C, Tables C8 and C9.

${ }^{20}$ While it is potentially possible to "buy" board seats in the form of excessive compensation for service, it less likely that firms would be willing to give away greater than a $10 \%$ ownership stake in the firms to a politician in most circumstances. These properties of the political connections data should help relieve some concerns about them being endogenous. If politicians are perceived to be abusing office for personal gain they are likely to be held accountable and removed by election in democratic systems or forcibly in authoritarian ones. For example, consider the reason for Berlusconi's short first term in 1994 or for the 2006 coup ousting Shinwatra in Thailand. Nevertheless, following the analysis I return to robustness/endogeneity concerns.

${ }^{21}$ Both were used by Acemolgu and Johnson (2005); the key difference between their measures of property rights and
} 
PropInst $_{k}$ represents property rights institutions; higher values indicate weaker property rights.

PropInst $_{k}$ is based on two popular measures: the International Country Risk Guide (ICRG) Expropriation Risk Index and the Freedom House Property Rights Index. ${ }^{22}$ The variable

ContractInst $_{k}$ represents contracting institutions; higher values indicate stronger contracting.

The underlying data was coded by the Center for International Financial Analysis \& Research

andwas featured as the key measure of contracting institutions, in La Porta et al.'s (1998)

seminal work on law and finance; the data also features in the cross-listing literature. ${ }^{23}$ These data sources are not perfect and, hence, not free from criticism; however, they are the most widely

used because they the best available measures for quantifying institutional quality.

\subsection{Control Variables}

\subsubsection{Other Firm-level Determinants of Cross-listing}

The firm-level control variables I include in my regressions of the determinants of crosslisting — size, leverage, return on assets, and capital intensity — are are typically the only firmlevel controls deemed essential in the broader literature exploring the determinants of crosslisting (Leuz and Oberholzer-Gee 2006; Doidge et al. 2009). I use the standard definitions. ${ }^{24}$

\subsubsection{Industry-level Indicators}

Indicators of firm's industry come from Datastream/Worldscope; I use these indicators to create dummy variables for each industry: $d_{\mathrm{j}} .{ }^{25} \mathrm{I}$ also use these indicators to exclude firms in the financial industry from my sample as is standard in the literatures on cross-listing (Doidge et al.

contracting institutions and mine is that I re-scale the underlying data, making it more readily interpretable in regression analysis. ${ }_{22}$ I take the Exprop_ICRG data from La Porta et al. (1998); which is "the risk of 'outright confiscation' or 'forced nationalization'." I also take the PropRights_FH data from La Porta et al. (2002); "The score is based, broadly, on the degree of legal protection of private property, the extent to which the government protects and enforces laws that protect private property... and the country's legal protection to private property." Rather than using each Exprop ICRG and PropRights_FH separately, I rescale and combine the data using principal components to project the PropRights $F \bar{H}$ measure onto Exprop ICRG, creating in essence a weighted average that should maximize the underlying signal from each data series. I first rescale the data such that the higher the score is the lower the value of the index and such that I divide by the weakest possible value of the index, making 1 the maximum value in the data. Principal components leads me to a final measure is 86\% Exprop_ICRG and 14\% PropRights_FH. ${ }_{23}$ get similar regression results in my analysis, however, if I use either measure separately or an equally weighted average. ${ }_{23}$ The original data is coded on a 0 to 90 scale depending upon the inclusion/omission of 90 items that could appear on accounting statements; 90 represents perfection and 0 no disclosures. Sweden scored the highest (83) and Egypt (24) the lowest; the U.S. scored 71 as a benchmark for generally accepted practices. I rescale the data so that 0 corresponds U.S. levels and so that positive (negative) value indicate higher (lower) disclosures. I take each value, divide by the level in the U.S., and subtract 1. ${ }^{24}$ Firm size, $S I Z E_{i}$, is defined as the natural logarithm of Total Assets; Return on Assets, $R O A_{i}$, is defined as Operating Income divided by Total Assets; Capital Intensity, $C A P I N T_{i}$, is defined as Fixed Assets divided by Total Assets; and, Financial Leverage, $L E V_{i}$, is defined as Long-term Debt divided by Total Assets.

${ }^{25}$ The industries included are broadly defined: Basic Materials, Consumer Goods, Consumer Services, Financials, Health Care, Industrials, Oil \& Gas, Technology, Telecommunications, and Utilities. 
2004) and other types of corporate financing activities.

\subsubsection{Country-level Indicators and Other Country-level Variables}

Indicators of firm's home country also come from Datastream/Worldscope;I use these to create dummy variables for each firm's traditional home country: $d_{\mathrm{k}}$. To round out my analysis, I also gather country-level data on government ownership of banks (La Porta et al. 2002), and on the national culture of corruption (using Fisman and Miguel's 2009 innovative measure based on diplomatic parking tickets) . Additionally, I construct country-level incidences of political connections and of cross-listing. ${ }^{26}$

\subsection{Summary Statistics}

Table 1 provides a country-level correlation matrix. There are several things to notice. First, the correlation coefficient between the incidence of political connections and the incidence of cross-listings (0.026) low at a country-level, suggesting little if any country-level support for Proposition 1; this, however, does not preclude firm-level support. Second, the correlation coefficient between the incidence of political connections and the quality of property rights institutions (0.055) is relatively low. Third and finally, measures of both types of economic institutions, property rights and contracting, are highly correlated (0.551).

\section{$<$ Insert Table 1 Here $>$}

Table 2 slices the data in ways that provides preliminary support for all three propositions at a country level. The positive values in row 3 support Proposition 1: firms are more likely to cross-list if they are politically connected. The decreasing trend in row 2 values, moving from left to right, supports Proposition 2: fewer firms cross-list from weaker property rights countries. The increasing trend in row 4 values supports Proposition 3: politically connected firms are more likely to cross-list the weaker property rights are.

$<$ Insert Table 2 Here $>^{27}$

\footnotetext{
${ }^{26}$ I define these incidences by counting the number of firms in a given country in my sample that meet that criteria and dividing that value by the total number of firms in my sample in that country.

${ }^{27}$ Additional summary statistics and views of the data appear in Appendix C.
} 


\section{Empirical Determinants of the Political Economy of Cross-listing}

I use the three propositions presented in the analytic framework section as a guide to structure how I add the domestic firm-level political connections variable and the domestic economic institutions variables to binary choice regressions predicting whether or not a firm cross-lists, using alternative explanatory factors (namely firm size) and core corporate financing characteristics as controls. Ideally, I could accurately estimate a single fully-specified regression model that could be used to simultaneously test all three of my propositions, taking the form:

$$
\operatorname{Pr}\left[y_{i}=1\right]=\Lambda\left(\beta \cdot[\text { Variables of Interest }]+\gamma_{i} X_{i}+\gamma_{k} Y_{k}+\gamma_{j} Z_{j}+\varepsilon_{i j k}\right)
$$

where Variables of Interest represents all of the political economy variables in my propositions (including the interacted variables); $X_{i}$ represents firm-level controls; $Y_{k}$ represents country-level controls; and $Z_{j}$ represents industry-level controls.

Attempting to estimate a fully-specified version of the statistical model could be problematic, however, since misspecification of the true model can be more costly in binary choice models than in simple linear models and can lead to greater bias/ inconsistent coefficient estimates. Consequently, I will take a more cautious approach and test each proposition separately, using dummy variables to hold higher-level explanatory variables in the multi-level structure constant. When I am interested in estimating coefficients on firm-level determinants of cross-listing behavior or on interactions between firm-level determinants and country-level factors, I estimate regressions of the form:

$$
\operatorname{Pr}\left[y_{i}=1\right]=\Lambda\left(\beta \cdot[\text { Variable of Interest }]+\gamma_{i} X_{i}+\sum_{\forall j} \gamma_{j} d_{j}+\sum_{\forall k} \gamma_{k} d_{k}+\varepsilon_{i j k}\right)
$$

where Variable of Interest represents the political economy variable in the proposition being tested; $X_{i}$ represents firm-level controls; $d_{\mathrm{j}}$, industrydummies; and $d_{\mathrm{k}}$, country dummies. ${ }^{28}$

The advantage of this model, over the fully-specified one, is that we do not need values of $Y_{k}$ and $Z_{j}$, nor do we need to know what all of the true country-level and industry-level factors

\footnotetext{
${ }^{28}$ This approach is useful for testing Proposition 1 and 3. When I test Proposition 2 (about the role of country-level economic institutions in cross-listing) I can no longer include the country dummy variable $\left(d_{\mathrm{k}}\right)$, since its inclusion effectively holds all country-level factors, including economic institutions, constant; a longer discussion of issues this creates is included with the test. I use multivariate logit in all tests since it is the most widely-used discrete choice method (Train 2003) and is used by Doidge et al. (2009) in their study of the determinants of cross-listing. I find similar results throughout if the density function inverted is either Gaussian (as in probit) or Extreme Value (as in gompit); likewise, I find similar results using a linear probability model.
} 
are that influence firms' cross-listing choices - eliminating all concerns about country- and industry- omitted variable bias or misspecification from the inclusion of 'incorrect' variables. While my estimate of $\beta$ will remain consistent in estimating this model, the disadvantage of the dummy-variable model vis-à-vis the fully-specified model is that my coefficient estimates will lose econometric efficiency. This efficiency loss biases against finding support for my propositions as it is less likely that I find statistically significant values for all coefficients, including those on my variables of interest.

The firm-level controls included in $X_{i}$ are firm size $\left(S I Z E_{i}\right)$, return on assets $\left(R O A_{i}\right)$, capital intensity $\left(C A P I N T_{i}\right)$, and financial leverage $\left(L E V_{i}\right)$. The logic for each is simple. Size is important to include since it is the best non-political economy factor at predicting if a firm crosslists; the reasons are varied: larger firms can better bear direct costs of cross-listing (Doidge et al. 2004), larger firms tend to be better appreciated by foreign investors, and larger firms are more likely to exhaust domestic capital markets. Return on assets helps control for firmprofitability to ensure that the results do not simply capture firms that have been more profitable/successful being more likely to cross-list. ${ }^{29}$ Capital intensity is important to include because it proxies for firms' financing needs. Finally, leverage is included because it controls for what type of capital firms tend to raise (debt or equity); furthermore, if politically-connected firms receive domestic debt on favorable terms, it helps control for this difference between connected and un-connected firms. ${ }^{30}$ In principle we may want to consider the inclusion of other firm-level controls; however, the combination of corporate financing characteristics that I include is sufficient. ${ }^{31}$ Nevertheless, in a quick robustness check, I will appeal to Bertrand et. al

\footnotetext{
${ }^{29}$ Tobin's Q is not an appropriate alternative for ROA, or an appropriate control, since Doidge et al. (2004) write and validate empirically a theory showing firms will have a higher Tobin's Q after they cross-list as a result of reduced agency conflicts. ${ }^{30}$ While some argue that political connections make firms more highly leveraged (Faccio et al. 2006), others find that firms with stronger political ties are less likely to be highly leveraged (Myers 2007).

${ }^{31}$ For example, Doidge et al. (2009), explore as additional firm-level controls a measure of 'foreign sales' and an indicator of 'government owned' firms. A measure of 'foreign sales' is not readily available in Worldscope for the majority of firms in my sample - a concern Doidge et al. (2009) have with including it in their own work and one that they address by saying that its omission does not alter their results; furthermore, if I include both firm size and industry indicators in my regression I am likely to be capturing some of the effects of foreign sales since the larger firms in an industry are more likely the ones that are exporting. Again, I am not able to reconstruct the variable 'government owned' for a large sample of firms in my dataset, but believe that if anything omitting it may bias against my findings since in many ways government ownership is an even more extreme version of political connectedness than the measure I use. Leuz and Oberholzer-Gee (2006) use a measure of firm 'age' in some robustness checks. They construct this variable based on original research into the incorporation dates of the 130 Indonesian firms in their sample; however, this is infeasible for the 12,395 firms in my sample.
} 
(2000) to show unobservable firm-level factors are unlikely to drive my results.

\subsection{The Role of Domestic Political Connections}

The first of several relationships I test is if and how domestic political connections influence firms' propensities to cross-list in any equity market outside of its home country (Proposition 1). To do so, I estimate variations of the following regression, including and omitting combinations of industry and country dummies:

$$
\operatorname{Pr}\left[y_{i}=1\right]=\Lambda\left(\beta \cdot d_{-} \text {connect }_{i}+\gamma_{i} X_{i}+\sum_{\forall j} \gamma_{j} d_{j}+\sum_{\forall k} \gamma_{k} d_{k}+\varepsilon_{i j k}\right)
$$

where $d_{-}$connect ${ }_{i}$ represents my dummy variable for politically connected firms; $X_{i}$ represents the firm-level controls; $d_{\mathrm{j}}$, industry dummies; and $d_{\mathrm{k}}$, country dummies. In these regressions, I treat a firm having a political connection as being exogenous to whether it cross-lists, an assumption I believe to be reasonable, but one that I return to in a discussion of robustness concerns nevertheless.

If the coefficient $(\beta)$ on the connected firm dummy variable is positive and significant, it suggests that firms with political connections are more likely to cross-list than firms without them, supporting Proposition 1; if the coefficient is negative and significant, it would suggest that firms with political connections are less-likely to cross-list, casting doubts on Proposition 1.(A negative coefficient would also be more in line with Khwaja and Mian's (2005) conjecture that the mechanism is political interference with domestic bankers' decisions.)

The results of this estimation appear in Table 3 and provide qualified support for the proposition that firms with political connections are more likely than those without them to cross-list. In all cases, the results in Table 3indicate a positive coefficient of interest $(\beta)$. In columns 1 and 2, where I pool my results, across countries, without including any country-level control variables, the coefficients on the political connections variable are highly statistically significant (at the 1\% level). These results strongly support Proposition 1. In columns 3 and 4, I include country dummy variables to run the test within rather than across countries; here the statistical significance falls just outside conventional thresholds. Before rejecting Proposition 1, it is important to consider several plausible explanations for why the within country tests of 
political connections' effects on cross-listing barely meet conventional thresholds: 1) logit may not be the most efficient functional form; ${ }^{32} 2$ ) I lose econometric efficiency by estimating a dummy-variable model rather than a fully-specified model; ${ }^{33} 3$ ) I may miss nuanced differences in political connections by using a binary metric rather than one with variable intensities; ${ }^{34}$ or 4 ) domestic political connections have different effects on firms' propensities to cross-list depending upon the institutional environment, as Proposition 3 suggests.

\section{$<$ Insert Table 3 Here $>$}

The marginal effect indicates that the average firm with political connections is approximately $15 \%$ more likely to cross-list than an unconnected firm across countries-a number that certainly is economically significant. ${ }^{35}$ Furthermore, the magnitude of this estimate and its significance may be understated to the extent that some political connections are unobserved or missing in the dataset such as: those gained through affiliations with business groups such as Korean chaebol or Japanese keiretsu (Khanna and Rivkin 2001); those sustained through family-owned firms (Bertrand and Schoar 2006; Morck and Yeung 2004); or, those sustained in state-owned enterprises including after privatizations.

Column 5 of Table 3 is included as a robustness check; it omits all firm-level, industrylevel, or country-level controls. As in Bertrand et al. (2000), we can surmise that unobservable firm-level characteristics are unlikely to be driving the results since the coefficient $(\beta)$ on the connections variable hardly changes between column 1 and $5 .^{36}$ As another robustness check, I

\footnotetext{
${ }^{32}$ If I run Gompit regressions (inverting an Extreme Value distribution) rather than logit regressions (inverting a Logistic distribution) then the within country results are statistically significant at conventional levels. The gompit approach may in fact be more accurate considering the logistic distribution assumes that the distribution of the outcome variable is approximately symmetric or that the probability of a firm cross-listing is roughly fifty percent whereas the extreme value distribution does not symmetric and more likely to fit the data since closer to thirty percent of firms actually choose to cross-list.

${ }^{33}$ This explanation seems to carry weight since when I estimate a model that is fully-specified at the country-level (shown in the Appendix Table on 'Unpacking' the Country Dummy), my variable of interest meets the standard threshold for significance while its magnitude remains the exactly the same - consistent with a loss of econometric efficiency in the country-dummy model. ${ }^{34}$ Using Faccio's (2006) data, I must treat the intensity of all political connections as being equally strong when reality is that all connections probably are not created equal. Nothing, other than disaggregating her metric, can be done about this since Faccio's data is the best available on political connections across countries. I do this before moving on to tests of Proposition 2.

${ }^{35}$ This estimate comes from regressions run across countries (columns 1 and 2) which do not control for or condition on institutions, the level of development, or any other country-level factors. The marginal effect was calculated by dividing the logit coefficient by 4 - an approximation for evaluating marginal effects around the mean of other variables in logit regressions derived by Amemiya - as suggested in the graduate econometrics texts written by both Woolridge and Greene.

${ }^{36}$ Bertrand et al. (2000) argue that if the magnitude of the coefficient of interest remains stable when we increase the effective set of firm-level unobservable variables by dropping variables that are observable, then results are unlikely to be driven by unobservable characteristics. Here column 5 can be compared to column 1 which has no industry-level or country-level controls to check for the magnitude of potential biases caused by variables that are unobservable or on which reliable data does not exist.
} 
used alternate measures of firm size in the regression. When I use either total assets or total assets squared as a measure of firm size — both of which emphasize the larger firms more than the log of total assets - my results become stronger. ${ }^{37}$

\subsubsection{Does the Variety of Political Connection Matter?}

The political connections data can be disaggregated into various types. There were two roles these political counterparties could play at the connected firms: owners or directors. There were three varieties of political counterparties in the data: members of government (i.e. Executives or Ministers), close relations to key politicians (i.e. members of government's families), and members of parliament. In Table 4, I examine the role different varieties of political connections play, by running regressions of the form:

$$
\operatorname{Pr}\left[y_{i}=1\right]=\Lambda\left(\beta \cdot d_{-} \text {connect_variety }{ }_{i}+\gamma_{i} X_{i}+\sum_{\forall j} \gamma_{j} d_{j}+\sum_{\forall k} \gamma_{k} d_{k}+\varepsilon_{i j k}\right)
$$

where $d_{-}$connect_variety ${ }_{i}$ represents the variety of political connection; $X_{i}$ represents the firmlevel controls; $d_{\mathrm{j}}$, industry dummies; and $d_{\mathrm{k}}$, country dummies.

\section{$<$ Insert Table 4 here $>$}

In columns 2 through 4 of Table 4, we can see how politicians' ownership or control roles affect firms' cross-listing propensities. Connections to politicians with large ownership stakes increase the probability that a firm cross-lists by nearly $19 \%$ within countries, whereas connections through political directorships (control) have no measurable effect on whether firms cross-list. While the design of the study and looking at cross-listing as an outcome should alleviate endogeneity concerns, these regressions also help address potential reverse causality concerns. Firms fail to gain the benefits of political connections simply by "buying politicians" to put on their boards; rather politicians look out for their own financial interests when making and enforcing legislation (Tahoun and van Lent, 2010). ${ }^{38}$

\footnotetext{
${ }^{37}$ These alternative size-measure tests are shown in the Appendix. Their findings are inconsistent with a skeptical interpretation of my results suggesting that the only reason that I find a significant relationship between firm-level political connections and cross-listing decisions is because only larger firms are politically connected. Furthermore, boxplots depicting categorical firm level summary statistics (broken out by political status of firms) also shown in the Appendix, show no major differences in the size distribution of connected/unconnected firms across countries.

${ }^{38}$ It is unlikely that politician-owners are simply given greater than a $10 \%$ stake in firms, rather than having chosen to hold ownership stakes on their own accord; directors, on the other hand, could bought through excessive compensation for their attendance at a few board meetings.
} 
In columns 5 through 8 of Table 4, we can see the effect on cross-listing of firms' various domestic political counterparties. For the average firm, a connection with a Member of Parliament does not affect its propensity to cross-list; however, connections with Ministers do increase the propensity that a firm maintains a cross-listing by about $18 \%$ within countries. Firms with connections to key politicians' close families also see a positive effect on crosslisting, although a smaller one than with the politician himself. If we expect, as in Baron and Ferejohn (1989), that Ministers are more able to set the policy agenda and control enforcement than legislators, then my results are consistent with a story about connected politicians' ability to assist connected firms by passing favorable legislation or delivering firm-specific property rights.

\subsection{The Role of Economic Institutions}

Proposition 2 (that firms are more likely to cross-list if they operate in higher quality domestic economic institutions' environments) is essentially a country-level prediction, so I first examine the relationship between domestic economic institutions and the country-level incidence of cross-listings. I run country-level bivariate regressions of the institutions measures on the incidence of cross-listing. The results, shown in Figure 1 for property rights institutions and Figure 2 for contracting institutions, confirm the correlations predicted in Proposition $2 .^{39}$

\section{$<$ Insert Figure 1 Here $>$ \\ $<$ Insert Figure 2 Here $>$}

To test further the relationship between institutions in firms' home country and firms' propensity to cross-list in any other country, Ialso run regressions of the general form:

$$
\operatorname{Pr}\left[y_{i}=1\right]=\Lambda\left(\beta \cdot Y_{k}+\gamma_{i} X_{i}+\sum_{\forall j} \gamma_{j} d_{j}+\varepsilon_{i j k}\right)
$$

where $Y_{k}$ represents either my measure of property rights( PropInst $_{k}$ ) or my measure of contracting (ContractInst ${ }_{k}$ ); $X_{i}$ represents firm-level controls; and, $d_{\mathrm{j}}$, industry dummies.

A negative and significant coefficient $(\beta)$ on the variablePropInst ${ }_{k}$ would

\footnotetext{
${ }^{39}$ I also run country-level multivariate regressions (not shown) that include both varieties of domestic economic institutions and continue to find coefficients with the predicted sign; however, the coefficients are not statistically significant because of limited degrees of freedom (as there are only 37 countries with sufficient data). The signs on the coefficients also remain as predicted by Proposition 2 when I add country averages of my firm-level controls to the regressions.
} 
supportProposition 2 (indicating that weaker domestic property rights institutions make firms less likely to cross-list), while a positive and significant coefficient $(\beta)$ on ContractInst $_{k}$ would also support Proposition 2 (indicating that firms with stronger domestic contracting institutions are more likely to cross-list). Results of these firm-level tests appear in Table 5. Each broadly supports Proposition 2, showing that firms are more likely to cross-list when they have higher quality domestic economic institutions.

\section{$<$ Insert Table 5 Here $>$}

The setting poses two empirical challenges: 1) my measures of contracting institutions and property rights institutions are highly correlated; and, 2) I can no longer include the country dummy-variable $\left(d_{\mathrm{k}}\right)$ to hold constant all country-level factors that influence cross-listing.

In Table 5, I run tests for contracting institutions and property rights institutions separately; this is a common way to deal with multicollinearity (that my key independent variables are highly correlated). ${ }^{40}$ The regressions in columns 1 and 2 support the proposition that stronger domestic property rights institutions are associated with increased firm propensities to cross-list. The regressions in columns 3 and 4 support the proposition that stronger contracting institutions are associated with increased firm propensities to cross-list. At a minimum all four of these regressions show that the partial correlations are those predicted in Proposition 2.

Testing the role of a specific country-level political economy variable precludes the use of country dummy variables. If the country-level political economy variable of interest does not sufficiently control for the roles of all country-level factors, these regressions may suffer from a country-level omitted variable bias. Nevertheless, I should still be picking up meaningful partial correlations between country-level economic institutions and firms' cross-listing decisionscorrelations useful in evaluating Proposition 3,regarding how the role of political connections depends on the institutional context, which was the primary point of this exercise and in discussing Proposition 2.

\footnotetext{
${ }^{40}$ See Woolridge's graduate-level econometrics text.
} 


\subsubsection{Attempting to 'Unpack' the Country Dummy Variables}

Ideally, we would know what country-level factors, other than contracting and property rights institutions, are absorbed by the country dummies included in some of my multi-level logit regressions. With that knowledge, I could also estimate a fully-specified regression model that simultaneously tests all three of my propositions. Unfortunately, there are an endless number of country-level variables that may influence cross-listing. Furthermore, many of these variables are highly correlated and the degrees of freedom in the estimation are effectively highly limited (since there are only 46 countries in my sample). Specification searches attempting to 'unpack' the country dummy variable reveal that both the signs and significance levels of coefficients on variables other than property rights and contracting institutions change depending upon the various combinations of conditioning variables. Consequently, most country-level variables, except for economic institutions, have difficulty standing up to the scrutiny of an extreme bounds analysis as suggested by Leamer (1985) or Sala-i-Matin (1997).The possibilities I explored nonetheless include measures of: legal origin (La Porta et al. 1998);cultures of rule breaking such as unpaid diplomatic parking tickets (Fisman and Miguel 2007); importance placed on trust, religion, and politics (World Values Surveys); and religious affiliations. ${ }^{41}$

\subsection{Domestic Political Connections Interacted with Economic Institutions}

With a basis for understanding the independent roles domestic political connections and domestic economic institutions play in firms' cross-listing choices, we can explore their interactions. To test the interaction relationship (Proposition 3), I run regressions of the form:

$$
\operatorname{Pr}\left[y_{i}=1\right]=\Lambda\left(\beta \cdot d_{-} \text {connect }_{i} \cdot Y_{k}+\gamma_{i} X_{i}+\sum_{\forall j} \gamma_{j} d_{j}+\sum_{\forall k} \gamma_{k} d_{k}+\varepsilon_{i j k}\right)
$$

where $d_{-}$connect $t_{i}$ represents my dummy variable for politically connected firms; $Y_{k}$ represents any country-level variable, but of primary interest is the measure of property rights institutions (PropInst $\left.{ }_{k}\right) ; X_{i}$ represents the firm-level controls; $d_{\mathrm{j}}$, industry dummies; and $d_{\mathrm{k}}$, country dummies.As in my test of Proposition 1, I treat firms' political connections as being exogenous to firms' cross-listing decisions; I also treat the existence of political connections as being

\footnotetext{
${ }^{41}$ Firm-level regressions testing these appear in Appendix C.
} 
independent from the institutional environment. ${ }^{42}$

If Proposition 3-that cross-listing is more likely for politically connected firms when domestic property rights institutions are weak - holds, we should expect the coefficient $(\beta)$ to be positive and significant on the interaction between the political connections dummy variable and my measure of property rights institutions (i.e. the coefficient on $d_{-}$connect $_{i} \cdot$ PropInst $_{k}$ ). Results strongly supporting Proposition 3 appear in Table 6.

Column 1 shows the baseline specification. The partial marginal effect suggests that ceteris paribus the average politically connected firm in a country with property rights institutions at the level of those in Thailand or Greece is approximately 11 or $12 \%$ more likely to cross-list than a politically-connected firm in a country with property rights institutions at the level of those in the United States or the United Kingdom. ${ }^{43}$

In column 2, I add an independent effect for political connections to the baseline specification. Doing so allows me to test whether some fraction of the political influence mechanism's effect works through an alternate channel besides property rights institutions; if this were the case, contrary to Proposition 3, we would expect this variable's coefficient to be independently statistically significant. It is not. ${ }^{44}$

\section{$<$ Insert Table 6 Here $>$}

I can also use the same general framework to test the validity of alternative hypotheses that involve the interaction between firm-level political connections and country-level factors $\left(d_{-}\right.$connect $\left._{i} \cdot Y_{k}\right)$ in Table 6 . The primary existing explanation for why politically connected firms receive better access to financing has to do with politicians' ability to coerce domestic bankers into offering terms they would not otherwise (Dinç 2005; Khwaja and Mian 2005). If this existing hypothesis held across countries, we would expect political connections to

\footnotetext{
${ }^{42}$ A discussion of why these decisions are reasonable is included in a discussion of potential robustness concerns.

${ }^{43}$ If we instead used regression results in column 3, 5, or 7 of Table 6 our marginal effects might be larger, so these numbers may be understated when considering the total effect. Ai and Norton (2003) show that interpretation of total interaction effects in non-linear models is not as straightforward as it is in linear models. I am, however, interested in the partial marginal effect, not the total marginal effect, so their concerns do not apply. Nonetheless, one simple solution has been to estimate instead linear probability models as a check (e.g. Osili and Paulson (2008) do this); I get approximately the same results when I do.

${ }^{44} \mathrm{We}$ cannot accept the hypothesis that there is an independent effect of political connections as its value is close to zero, suggesting that the empirical model in Column 1 is specified correctly while that in Column 2 is specified incorrectly. Furthermore, Column 2 shows that the coefficient on the interaction term remains stable, despite the potential misspecification.
} 
be most valuable for securing domestic bank finance instead of foreign equity finance in countries where governments control banks. Hence, if political coercion of domestic bankers were the primary mechanism through which influential firms obtained financing on favorable terms, we would expect an interaction between firms' political connections and government ownership of banks to be negative and significant in a regression on cross-listing activity. We might expect the same, negative and significant coefficient, for political connections interacted with weak contracting institutions or cultures of corruption, if we thought those country-level factors improved politically-connected firms' financing opportunities in their home-country.

In columns 3 through 8 of Table 6 , I include in my regressions interactions with: (i) the fraction of government-owned bank assets (La Porta et al. 2002); (ii) the quality of domestic contracting institutions captured by accounting disclosures (La Porta et al. 1998); and, (iii) the national "culture of corruption" using Fisman and Miguels's (2007) diplomatic parking ticket measure. ${ }^{45}$ None of the coefficients on these alternative interactions with the political connections measure (included as tests of the existing gun-to-the-head or quid-pro-quo mechanism hypotheses as an alternative to my Proposition 3) are statistically significant and some of their signs flip depending upon conditioning variables. This additional evidence further suggests that political coercion of domestic bankers is not the primary mechanism through which politically connected firms receive favorable financing. The inclusion of alternative interaction terms in the regression may even strength the core finding about the interaction between political connections and property rights institutions, as the coefficient value on the $d_{-}$connect $_{i}$. PropInst $_{k}$ variable increases when the alternative interactions are included in the statistical framework. Taken together, the results in Table 6 strongly support Proposition 3: ceteris paribus the weaker the property rights institutions environment is, the stronger the effect domestic political connections have on whether a firm cross-lists.

\footnotetext{
${ }^{45}$ All of these alternative country-level factors $\left(Y_{k}\right)$ are highly correlated with property rights institutions (as seen in Table 1's country-level correlation matrix). This suggests that we are very likely to find a statistically significant interaction with these alternative variables, especially if the logic that political connections help protect firms from weak formal property rights institutions is not the primary reason that politically-connected firms are more-likely to cross-list.
} 


\subsubsection{Partial versus Total Interaction Effects}

To be consistent with Proposition 3, the above regressions explore the partial interaction between domestic political connections and domestic property rights institutions. We may, however, also be interested in the total interaction effects. Given Leuz and Oberholzer-Gee's (2006) valid finding that in Indonesia, a country with weak property rights, domestic political connections make firms less likely to cross-list (when we do not control for country-level factors), we should expect to find a different total relationship than the parital relationship explored in Table 6. Otherwise, we could not reconcile the replicable Indonesian result ${ }^{46}$ with my findings. Next I explore total rather than partial interactions, showing that we can reconcile the seemingly contradictory findings between this research and that conducted by Leuz and Oberholzer-Gee (2006) and Siegel (2009).

One way to understand how the total effect of political connections varies with property rights (without a fully specified econometric model requiring explicit knowledge of all countrylevel factors) is by stratifying the sample into groups of countries by relative levels of property rights institutions and re-running my regressions. Doing so better enables us to explore the total effect of political connections - conditional on firms being located in countries with different levels of property rights institutions-rather than just the partial effects. ${ }^{47}$

Results from stratifying the sample, by country-level quartiles of property rights, appear in Table $7 .{ }^{48}$ The regressions indicate that the partial interaction, in Proposition 3, does not tell the whole story of the relationship between political connections and cross-listing. If the total relationship mirrored the partial relationship, we would expect the coefficient on the political connections variable to get larger as property rights institutions become weaker (i.e as we move from the first column to the last). It does not. The coefficient on political connections is not

\footnotetext{
${ }^{46}$ I replicate Leuz and Oberholzer-Gee's (2006) findings in an Appendix table. In my regression, while this coefficient is negative, it is not statistically significant; this likely stems from the one difference between my regression and Leuz and Oberholzer-Gee's (2006): their measure of political connectedness attempts to incorporate the strength of political ties, while my measure from Faccio (2006) is only a dummy variable that captures whether or not a firm is politically connected. Consistent with Proposition 1 (as seen in Table 3, column 1) I find the opposite result when expanding the sample beyond Indonesian firms.

${ }^{47}$ This also assuages concerns about the interpretation of interaction coefficients in non-linear regressions (Ai and Norton 2003) ${ }^{48}$ There may be some concern that the choice of quartiles as a means of stratifying the sample into different groups of countries by institutional quality is a somewhat ad-hoc econometric approach. These concerns are valid; however, the choice of alternate thresholds of institutional quality for grouping countries reveals the same general pattern as using quartiles in Table 7.
} 
statistically significant in either the countries with the strongest (Q1 in column 1) or weakest(Q4 in column 4) property rights; it is statistically significant only for the middle two quartiles. Hence, the total relationship between firms' domestic political connections and cross-listing decisions attenuates in environments at both extremes of institutional quality.

\section{$<$ Insert Table 7 Here $>$}

We can conjecture about why we see attenuation in the total effect political connections have on cross-listing. At one extreme, in countries with the strongest property rights, being connected may do little to help firms because formal domestic property rights are sufficient or difficult to enhance. Firms in these economies may gain little even when politicians help them, making connections impact immeasurably small. At the other extreme, in the weakest property rights environments, in addition to receiving property rights support, politically-connected firms may also be recipients of preferential financing due to politicians' interference with local bankers, reducing the firms' attractiveness to foreign capital market participants. These latter results may be consistent with Leuz and Oberholzer-Gee's (2006) and Siegel's (2009) stories about why firms with political connections choose not to cross-list, particularly since those researchers found empirical support in Indonesia and Mexico, countries at the bottom end of property rights spectrum in my sample. Their story might also hold in countries outside my sample with extremely weak domestic property rights, under-developed domestic equity markets, and few cross-listings; Pakistan, which Khwaja and Mian (2005) studied and found support for the mechanism, is among those countries as well.

A related explanation for the why we see attenuation at the weak property rights end of the spectrum might have to do with a critical threshold value of the political connections. If a political connection could be worth more to the firm than $10 \%$ of the firms' market value (the threshold level for a firm being defined as having a politician-owner in my data), then firms may be willing to give away ownership stakes greater than that $10 \%$ level in exchange for political benefits. Such an exchange could explain the attenuation I observe in the weakest property rights countries, since, at least in the Indonesian case, a political connection can be worth more 
than $25 \%$ of the market value of the firm (Fisman 2001). Consequently, we might see that politicians in extremely weak property rights countries are more exploitative of firms than beneficial, scaring off the foreign investor community.

\subsubsection{The Role of Political Institutions in Creating Value for Politically Connected Firms}

Home country political institutions — such as autocracy or democracy; a right, left, or center government; and, years a government held office - may also shape the value of firms' political connections in accessing finance; therefore, I tested interactions between domestic firmlevel political connections and country-level political institutions variables (using the same framework as for economic institutions). To my surprise, most of the findings were null, with none reaching statistical significance at the standard levels. The political institutions data I used in my tests came from the World Bank's Database of Political Institutions (Beck et al. 2001).

\subsection{Addressing Robustness Concerns}

I believe my findings are robust; however, some readers may question assumptions I made throughout my analysis. I address these concerns here.

\subsubsection{Endogeneity of Domestic Political Connections to Firms' Cross-listing is Unlikely}

One of the reasons I study political connections effect on cross-listing rather than domestic debt financing as an outcome in this study was to help resolve endogeneity issues. The type of political connections I observe, where high-level political figures are owners of or directors at firms, seem unlikely to be obtained for the explicit purpose of cross-listing; likewise, cross-listings are unlikely to exist for the explicit purpose of gaining political connections. ${ }^{49}$ It is unclear how a large shareholder, officer, or director of a firm advising his firm to maintain a cross-listing has any direct influence as to whether or not he could go on to win an election or secure a political appointment. Furthermore, the data showed that simply installing politicians to boards of directors has little demonstrable effect on firms' cross-listing behavior as shown in Table 4. It is also unclear how any domestic political actor would become a top officer or major

\footnotetext{
${ }^{49}$ Furthermore, several authors have argued that the types of political connections in my data are a function of chance rather than an explicit calculation on either firms' or politicians' part (e.g. Johnson and Mitton 2003; Faccio 2006; Fisman and Miguel 2008).
} 
shareholder of a firm simply because that firm chose to cross-list; in fact, we might expect domestic politicians' ownership stakes fall since cross-listings typically attract a broader, more diverse shareholder base (Aherane et al. 2004; Edison and Warnock 2004). ${ }^{50}$

Given the existing narratives on how political influence leads to preferential financing terms (i.e. through interference with local bankers decision-making processes), if there were any bias in my empirics from an endogenous relationship, the bias would run in the opposite direction of my results, suggesting my magnitudes are under-estimated. ${ }^{51}$ Furthermore, politically connected firms have incentives not to reveal information about illicit benefits political influence affords them (Chaney et al. 2008) as is required of firms that cross-list (Leuz and Oberholzer-Gee 2006); this story also runs the opposite direction of my results.

In many ways, the identification strategy I employ (of observing firm behavior in foreign markets) is similar to the one successfully implemented by Osili and Paulson (2008) who look at the personal finance decisions of international migrants to the United States; they isolate holdover home country effects on individuals' behavior when their US market activity is observed instead of their home country activity. The difference is that I look at firms, not individuals.

\subsubsection{Endogeneity of Domestic Institutions to Firms' Cross-listing is Unlikely}

Concerns about the endogeneity of domestic institutions to economic outcomes primarily afflict country-level studies. By choosing to study a firm-level outcome concerns about domestic institutions being endogenous to a firm-level dependent variable (cross-listing activity) should be moot. Low-quality domestic institutions constrain firms that have little or no ability to directly influence their quality - since firms cannot fix institutional flaws, they must instead act strategically to avoid their ill effects. To believe endogeneity of institutions to firms' crosslisting decisions threatens my results, we would have to think that most firms select their home

\footnotetext{
${ }^{50}$ Ideally we would want to exploit data on the timing of cross-listing and the timing of firms acquiring political connections to get at these issues; however, we are limited to a cross-sectional dataset given the use of cross-country political connections data. Alternatively, we would ideally want to run a Cox proportional hazard analysis type test, as in Doidge, et al. (2009), to see if firms that are politically connected in the year of the cross-section (2002) are more likely to cross-list sooner thereafter than unconnected firms; unfortunately data availability constraints only give us the exact cross-listing dates for firms that cross-list into the US, which is only a fraction of all cross-listings and not necessarily a representative sub-sample.

${ }^{51}$ Recall that politicians can manipulate local bankers into offering preferential terms, which if anything should lead firms to favor domestic bank loans to foreign finance; however, it is unlikely that domestic politicians can manipulate foreign participants in dispersed capital markets who reside outside the institutional setting over which the politicians have dominion.
} 
institutional environment based on access to finance; in that case, we would expect all firms to locate in the countries with the best institutions, which we know does not happen. ${ }^{52}$

\subsubsection{Independence of Domestic Political Connections and Domestic Economic Institutions}

Another concern, particularly relevant to my tests of Proposition 3, might be about the assumption that the incidence of political connections in a country is independent of its institutions. The data verifies this: political connections are equally prevalent in both weak and strong institutional environments. ${ }^{53}$ Hence, political connections are not necessarily more common in places where the data suggests connections might be most valuable. The source of variation in observable domestic political connections across countries has more to do with apparently random (exogenous) regulations in individual countries against firm-politician relationships than it has to do with the quality of countries' domestic institutions (Faccio 2006).

\section{Discussion: Role of Political Connections in Access to Finance}

My empirical findings enhance our understanding of how and why political connections improve firms' access to finance. In most prior characterizations, political influence represents a mechanism that is useful primarily for domestic capital market manipulation by using politicians to coerce local bankers. Inconsistent with those stories, my findings show political connections improve firms' access to foreign finance in addition to domestic finance. My findings also support an alternate way to characterize the role political connections play: that role is providing tacit property rights support that reduces firms' risk premium.

In most cases, the preferential financing that politically connected firms receive is not likely the result of political interference with domestic bankers. Rather, preferential financing is more likely the result of rational decisions by financiers: financiers who observe firms' explicit political connections choose to offer better financing terms because they realize that politically

\footnotetext{
${ }^{52}$ If all firms located where the best institutions are we would expect to see every firm in the world located in places like Canada, Finland, Sweden or Switzerland; we know this does not happen. Furthermore, global firms often intentionally locate a portion of their operations in weak institutional environments to arbitrage wage/skill differentials.

${ }^{53}$ The correlation coefficient for the country-level incidence of political connections and property rights institutions is a meager 0.055 as show in the country-level correlation matrix in Table 1. Figure C9 in the Appendix shows a scatterplot that illustrates that political connections are not more prevalent in weak or strong institutional environments. Furthermore the few numerical estimates of the value of political connections at which other researchers have arrived using natural experiments appear to be uncorrelated with the incidence of political connections. For example, connections are very common in the UK, but worthless according to Faccio (2006).
} 
connected firms receive implicit property rights support as a result of their relationship with the government. If political connections afford firms the ability to operate as if they were in a superior property rights environment, then connected firms' cash flows will be more secure than otherwise similar firms', reducing the connected firms' relative risk premiums. Since firms with domestic political connections are less risky investments, they should receive relatively better financing terms and relatively better access to capital in well-functioning financial markets.

Domestic political connections should matter to foreign investors in addition to domestic investors because "it is necessary to examine both how the institutions are written and how they are implemented" (Siegel 2005).In the absence of political connections, domestic investors are likely to have a comparative advantage over foreign investors in understanding how domestic institutions are implemented; domestic investors are likely to better understand the specific risks their country's weak property rights institutions pose to any given firm. Given this reality, domestic political connections may matter more to foreign investors than domestic ones: foreign investors can take the signal political connections provide to mean that privileged firms have implicit property rights support when otherwise they may find it more difficult to evaluate the specific risks a weak domestic institutional environment poses.

My results suggest that political connections create efficiencies in the markets' ability to allocate capital by reducing the uncertainty in specific firms' property rights environment; this contrasts with stories about how political connections create inefficiencies in how the market allocates capital. Political connections serve as a second-best solution for firms that could benefit from stronger property rights protections but that face weak institutions. Of course, as a first-best solution, stronger national property rights would bolster the entire economy. Selectively enforced property rights make it easier for financiers to identify which firms to fund but do not eliminate aggregate inefficiencies caused by weak national property rights. Weak domestic property rights require firms to dedicate resources to finding strategies that prevent theft and asset taking - using political connections is one such strategy.

Another interesting implication is that (financial) globalization may, in fact, strengthen 
the position of firms with domestic political connections, since foreign financiers rationally fund firms that can influence their domestic policy environment; this subtly contrasts with stories about how incumbent industrialists should wield political power to oppose all forms of financial development/globalization as the incumbents have the most to lose (Rajan and Zingales 2003).

\section{Conclusion}

Using a unique, multi-level, cross-country dataset, my empirical analysis identifies two new political economy factors that improve firms' access to foreign equity finance: 1) domestic firm-level political connections, and 2) strong domestic country-level property rights. Moreover, when these two factors are interacted, their sign reverses - suggesting thatfirm-level political connections play a strategic role for firms as a substitute for national property rights regimes.

These findings extend our understanding of how and why political influence enables firms to obtain better financing terms. Political connections are useful not only for access to domestic finance, but also for access to foreign finance. The reason political connections improve access to all types of finance has more to do with (i) the provision of firm-specific property rights that reduce connected firms' risk premiums than with(ii) political interference in domestic banking.

My findings also help reconcile competing political economy stories about the primacy of either firm- or country-level political economy factors in explaining firms' cross-listing activity. Past explanations failed to consider interactions between firm-level political influence measures and country-level institutions measures as my study does. Furthermore, past studies of firmlevel political connections and cross-listing lacked external validity because they were executed in single-country environments. While single-country studies about political influence are and will continue to be valuable, we need to be cautious about generalizing their results.

As with all research, this article also has its limitations. One limitation, due to the crosssectional, rather than panel nature, of the data, is that we were unable to study the dynamics of political connections effects on firms' cross-listing behavior; having access to panel data or timeseries data within single countries could better help identify whether political connections serve as a signal that influential firms have a lower risk premium or whether markets only respond 
once politicians have done something explicit to enhance a firms' property rights environment thereby lowering their risk premium. Another limitation, caused by the cross-country nature of the research design and using firm-country interactions to evaluate alternative mechanisms, is that while we are able to identify that political connections primary role in improving access to finance appears to work through home-country property rights environment by reducing associated firms' relative country risk premiums, we cannot be more explicit on how; studies focused on chronicling all of the benefits individual politically connected firms receive would be necessary to distinguish whether the property-rights benefits connected firms receive come through new legislation with asymmetric benefits, selective enforcement of existing legislation, or through more nefarious channels. Alternative research designs and datasets, without the limitations of the current study, could prove fruitful in resolving these ancillary questions. 


\section{References}

Acemoglu, D, Johnson, S. and Robinson, J. 2001. "The Colonial Origins of Comparative Development: An Empirical Investigation," American Economic Review, XCI, 1369-1401.

Acemoglu, D. and Johnson, S. 2005. "Unbundling Institutions." Journal of Political Economy. 113:5, 949-995.

Acemoglu, D., Johnson, S. and Robinson, J. 2005. "Institutions as a Fundamental Cause of Long-Run Growth," Chapter 6 in the Handbook of Economic Growth, Volume 1A (Eds: Aghion, Philippe and Steven N. Durlauf) The Netherlands: Elsevier BV.

Agrawal, A. and Knoeber, C. 2001. "Do some outside directors play a political role?" Journal of Law and Economics 44, 179-198.

Ahearne, A.; Griever, W.; and Warnock, F. 2004. "Information costs and home bias: an analysis of U.S. holdings of foreign equities." Journal of International Economics 62:313-336.

Ai, C. and Norton, E. 2003. "Interaction terms in logit and probit models." Economic Letters. 80:123-129

Baron, D. and Ferejohn, J. 1989. "Bargaining in Legislatures.” American Political Science Review, 83, 1181-1206.

Beck, T.; Clarke, G.; Groff, A.; Keefer, P.; and Walsh, P. 2001. "New tools in comparative political economy: The Database of Political Institutions." World Bank Economic Review. 15:1, 165-176.

Bertrand, M., E. Luttmer, and S. Mullainathan, 2000. '"Network Effects and Welfare Cultures,' Quarterly Journal of Economics, CXV.

Bertrand, M. and Schoar, A. 2006. "The role of family in family firms." Journal of Economic Perspectives 20, 73-96

Bradshaw, M.; Bushee, B.; and, Miller, G. 2004. "Accounting choice, home bias, and U.S. investment in non-U.S. firms." Journal of Accounting Research. 42(5), 795-841.

Chaney, P.; Faccio, M.; and, Parsley, D. 2008. "The Quality of Accounting Information in Politically Connected Firms.” Unpublished Working Paper.[Available at SSRN:

http://ssrn.com/abstract $=966379]$

Charumilind, C.; Kali, R; and Wiwattanakantang, Y. 2006. "Connected Lending: Thailand before the Financial Crisis," Journal of Business, 79, 181-218.

Claessens, L.; Feijen, E.; and Laeven, L. 2008. "Political Connections and Preferential Access to Finance: The Role of Campaign Contributions" Journal of Financial Economics. 88:3, 554580 .

Coffee, J. 1999. "The future of history: The prospects for global convergence in corporate governance and its implications." Northwestern University Law Review, V93, 641-708.

Coffee, J. 2002. "Racing towards the top? The impact of cross-listings and stock market competition on international corporate governance." Columbia Law Review. 102, 1757-1831.

Coval, J. and Moskowitz, T. 1999. "Home Bias at Home: Local Equity Preference in Domestic Portfolios.” Journal of Finance. 45: 6, 2045-2073. 
Cull, R. and Xu, L. 2005.“Institutions, ownership and finance: The determinants of profit reinvestment among Chinese firms."Journal of Financial Economics 77, 117-146.

de Figueiredo, J., and Silverman, B. 2006. "Academic Earmarks and the Returns to Lobbying." Journal of Law \& Economics. 49, 597-625.

Dinç, S. 2005. "Politicians and banks: Political influences on government-owned banks in emerging markets."Journal of Financial Economics 77(2), 453-479

Doidge, C.; Karolyi, A.; and Stulz, R. 2004. "Why are Foreign Firms that List in the U.S. Worth More?" Journal of Financial Economics. 71:2, 205-238.

Doidge, C.; Karolyi, A.; Lins, K.; Miller, D.; and Stulz, R. 2009. "Private Benefits of Control, Ownership, and the Cross-listing Decision” Journal of Finance 64, 425-466

Edison, H. and Warnock, F. 2004. 'U.S. Investors' Emerging Market Equity Portfolios: A Security-Level Analysis." Review of Economics and Statistics 84(3), 691-704.

Faccio, M.2006. "Politically connected firms."American Economic Review.96, 369-386.

Faccio, M.; Masulis, R.; and McConnell, J. 2006. "Political Connections and Corporate Bailouts." Journal of Finance. 61:6, 2597-2635.

Ferguson, T. and Voth, H. 2008. "Betting on Hitler-The Value of Political of Connections in Nazi Germany." Quarterly Journal of Economics. 123:1, 101-137.

Fisman, R. 2001. "Estimating the Value of Political Connections." American Economic Review. 91:4, 1095-1102.

Fisman, R. and Miguel, E. 2007. "Corruption, norms, and legal enforcement: Evidence from diplomatic parking tickets." Journal of Political Economy 115:6

Fisman, R. and Miguel, E. 2008. Economic Gangsters: Corruption, Violence, and the Poverty of Nations. Princeton University Press.

Goldman, E.; So, J. and Rocholl, J. 2008. "Political Connections and the Allocation of Procurement Contracts."Working Paper at SSRN: http://ssrn.com/abstract=965888

Hail, L. and Leuz, C. 2009. "Cost of Capital Effects and Changes in Growth Expectations Around U.S. Cross-Listings." Journal of Financial Economics.

Henisz, W. 2000. "The Institutional Environment for Multinational Investment." Journal of Law, Economics and Organization. 16(2): 334-64

Hung, M.; Wong, T.; and Zhang, T. 2008. "Political relations and overseas stock exchange listing: Evidence from Chinese state owned enterprises." U. of Southern Cal. Working Paper [Available online at: http://ssrn.com/abstract=1224162]

Hutchcroft, P. 1998. Booty Capitalism: The Politics of Banking in the Philippines (Cornell University Press, Ithaca and London).

Johnson, S. and Mitton, T. 2003. "Cronyism and Capital Controls: Evidence from Malaysia." Journal of Financial Economics. 67:2, 351-82.

Kang, D. 2002. "Bad Loans to Good Friends: Money Politics and the Developmental State in South Korea." International Organization 56:1, 177-207. 
Karolyi, G. A. 2006. "The World of Cross-Listings and Cross-Listings of the World: Challenging Conventional Wisdom." Review of Finance. 10:1, 99-152.

Khanna, T., Rivkin, J., 2001. "Estimating the performance effects of business groups in emerging markets.” Strategic Management Journal 22, 45-74.

Khwaja, A. I., and Mian, A. 2005. "Do lenders favor politically connected firms? Rent provision in an emerging financial market." Quarterly Journal of Economics. 120, 1371-1411.

La Porta, R.; Lopez-de Silanes, F.; Shleifer, A.; and Vishny, R. 1998. "Law and Finance." Journal of Political Economy. 106:6, 1113-55.

La Porta, R.; Lopez-de Silanes, F.; and, Shleifer, A. 2002. "Government Ownership of Banks." Journal of Finance. 57:1.

Laeven, L. and Woodruff, C. 2007. "The Quality of the Legal System, Firm Ownership, and Firm Size." Review of Economics and Statistics. 89:4, 601-614

Lang, M.; Raedy, J.; and Wilson, W. 2006. "Earnings management and cross listing: Are reconciled earnings comparable to U.S. earnings?" Journal of Accounting and Economics 42, 255-283.

Leamer, E. 1985. "Sensitivity Analyses Would Help."American Economic Review.57(3),308-13.

Leuz, C. and Oberholzer-Gee, F. 2006. "Political Relationships, Global Financing and Corporate Transparency: Evidence from Indonesia." Journal of Financial Economics. 81:3, 411-439.

Li, H.; Meng, L.; Wang, Q.; and, Zhou, L. 2008. "Political connections, financing and firm performance: Evidence from Chinese private firms." Journal of Development Economics. 87(2), 283-299.

Licht, A. 2003. "Cross-listing and corporate governance: bonding or avoiding?" Chicago Journal of International Law 4, 141-163.

Malesky, E. and Taussig, M. 2009. "Where is Credit Due: Legal Institutions, Connections, and the Efficiency of Bank Lending in Vietnam." Journal of Law, Economics, and Organization, 25(2), 535-578.

Morck, R. and Yeung, B. 2004."Family Control and the Rent-Seeking Society."Entrepreneurship: Theory and Practice. 28:4, 391-409..

Myers, B. 2007. "Firms, Politicians, and Capital Structure" in Effects of the political process on financial topics. Ph.D. dissertation, University of California, Los Angeles, United States.

North, D. 1981. Structure and Change in Economic History. New York: Norton.

North, D. 1990. "Institutions and a transaction-cost theory of exchange" in Perspectives on Positive Political Economy (Alt, J. and Shepsle, K. eds.) Cambridge University Press. Ch. 7, p. 182.

Osili, U. and Paulson, A. 2008. "Institutions and Financial Development: Evidence from International Migrants in the United States." Rev. of Economics and Statistics. 90(3): 498-517.

Pagano, M.; Röell, A.; and Zechner, J. 2002. "The Geography of Equity Listing: Why Do Companies List Abroad?” Journal of Finance. 57(6): 2651-2694. 
Rajan, R.; and Zingales, L. 2003. "The great reversals: The politics of financial development in the twentieth century." Journal of Financial Economics. 69: 5-50.

Richter, B.; Samphantharak, K.; and Timmons, J. 2009. "Lobbying and Taxes." American Journal of Political Science 53:4, 893-909.

Roberts, B. 1990. A Dead senator tells no lies: seniority and the distribution of federal benefits. American Journal of Political Science, 34, 31-58.

Sala-i-Martin, X. 1997. "I Just Ran Two Million Regressions." American Economic Review. 87: 178-183.

Sarkissian, S. and Schill, M. 2004. "The overseas listing decision: New evidence of proximity preference." Review of Financial Studies 17, 769-809.

Siegel, J. 2005. "Can foreign firms bond themselves effectively by renting U.S. Securities laws?” Journal of Financial Economics. 75, 319-359.

Siegel, J. 2007. "Contingent Political Capital and International Alliances: Evidence from South Korea.” Administrative Science Quarterly 52(4), 621-666.

Siegel, J. 2009. "Do Foreign Firms Choose Not to Cross-List Because They Have Secured Better Alternatives? Evidence from Mexico" Journal of International Business Studies, forthcoming.

Stulz, R., 1999. "Globalization of equity markets and the cost of capital." Journal of Applied Corporate Finance. 12, 8-25.

Stulz, R. 2005. "The Limits of Financial Globalization.” Journal of Finance 60:4, 1595-1638.

Tahoun, A. and van Lent, L. 2010. "Personal wealth interests of politicians and government intervention in the economy: the bailout of the US financial sector." Working paper available online at: http://ssrn.com/abstract $=1570219$

Train, K. 2003. Discrete Choice Methods with Simulation. Cambridge University Press.

Xin, K.; and Pearce, J. 1996. "Guanxi: Connections as Substitutes for Formal Institutional Support." Academy of Management Journal 39: 1641-1658. 


\section{Figures and Tables}

Figure 1 - Country-level Relationship between Cross-listing Incidence and Property Rights Institutions The following figure shows the results of a bivariate country-level regression of property rights institutions on the incidence of cross-listings for a particular country in my sample.

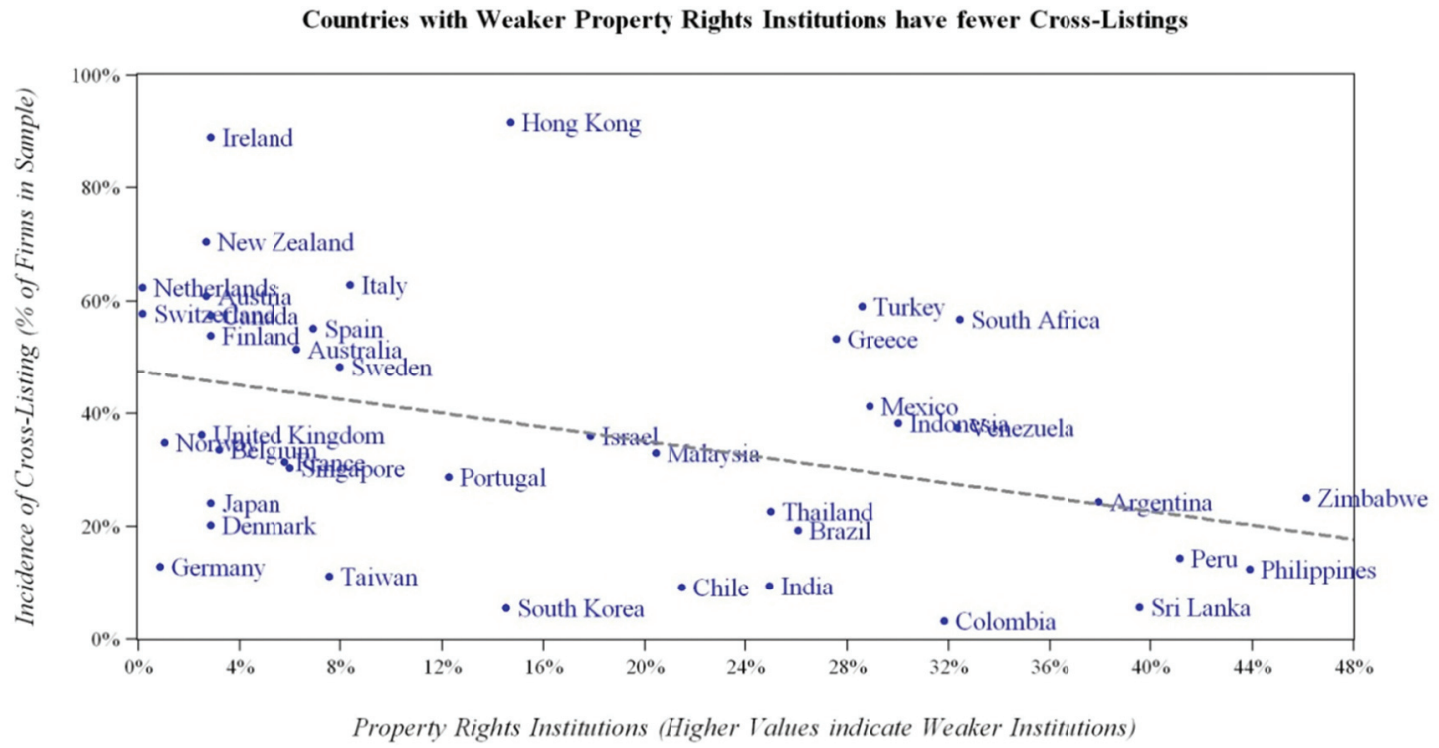

Figure 2 - Country-level Relationship between Cross-listing Incidence and Contracting Institutions

The following figure shows the results of a bivariate country-level regression of contracting institutions on the incidence of cross-listings for a particular country in my sample.

Countries with Stronger Contracting Institutions have more Cross-Listings

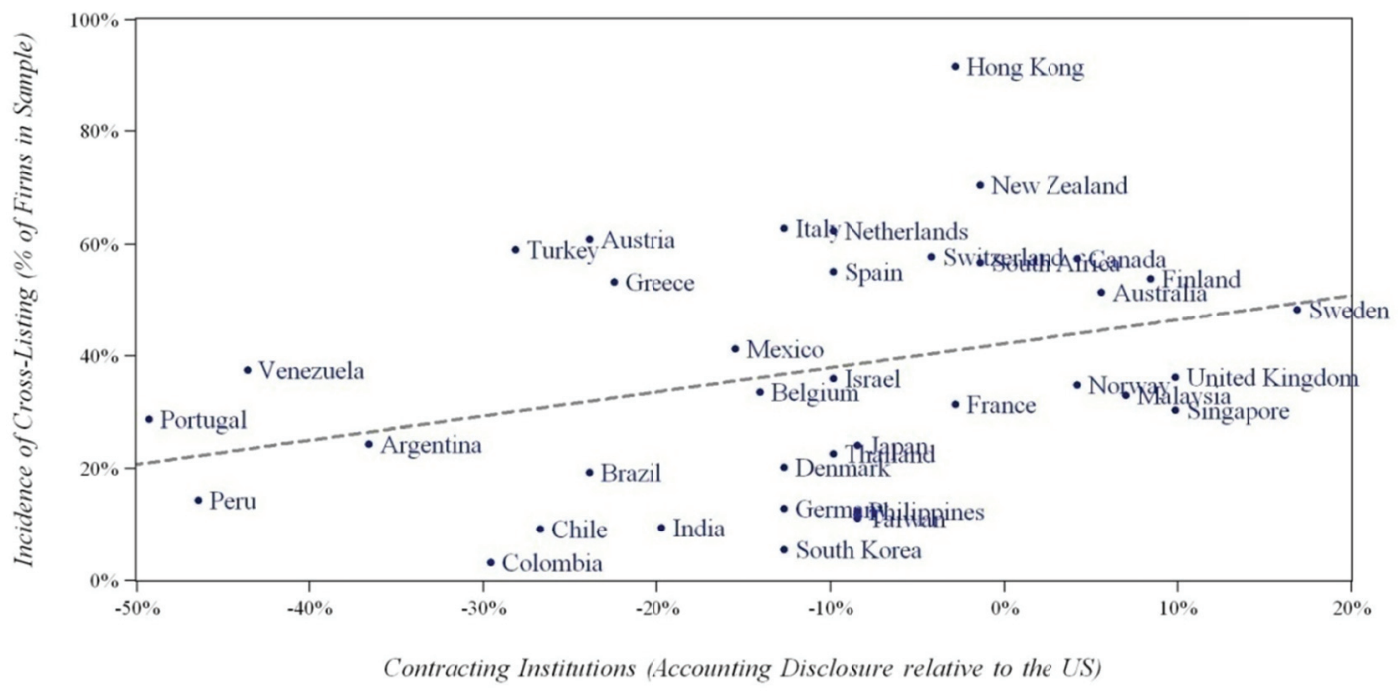


TABLE 1 - Country Level Correlation Matrix

\begin{tabular}{|c|c|c|c|c|c|c|}
\hline & $\begin{array}{c}\text { Strong } \\
\text { Property } \\
\text { Rights }\end{array}$ & $\begin{array}{c}\text { Weak } \\
\text { Contracting }\end{array}$ & $\begin{array}{c}\text { Incidence of } \\
\text { Political } \\
\text { Connections }\end{array}$ & $\begin{array}{c}\text { Incidence of } \\
\text { Cross- } \\
\text { Listings }\end{array}$ & $\begin{array}{c}\text { Government } \\
\text { Ownership of } \\
\text { Banks }\end{array}$ & $\begin{array}{l}\text { Culture of } \\
\text { Corruption }\end{array}$ \\
\hline Strong Property Rights & 1.000 & & & & & \\
\hline Weak Contracting & -0.551 & 1.000 & & & & \\
\hline $\begin{array}{r}\text { Incidence of Political } \\
\text { Connections }\end{array}$ & 0.055 & 0.270 & 1.000 & & & \\
\hline $\begin{array}{r}\text { Incidence of } \\
\text { Cross-Listings }\end{array}$ & -0.397 & 0.326 & 0.026 & 1.000 & & \\
\hline $\begin{array}{r}\text { Government Ownership } \\
\text { of Banks }\end{array}$ & 0.424 & -0.466 & -0.116 & -0.346 & 1.000 & \\
\hline Culture of Corruption & 0.547 & -0.165 & 0.167 & -0.157 & 0.003 & 1.000 \\
\hline
\end{tabular}

TABLE 2 - Country-level Incidence of Firms' Cross-listing, Categorical Means

\begin{tabular}{|c|c|c|c|c|c|}
\hline \multirow[b]{2}{*}{ Type of Firm: } & \multirow[b]{2}{*}{$\begin{array}{c}\text { All } \\
\text { Countries }\end{array}$} & \multicolumn{4}{|c|}{ Countries' Property Rights Quartiles } \\
\hline & & $\begin{array}{c}\mathbf{Q 1} \\
\text { (Strongest) }\end{array}$ & Q2 & Q3 & $\begin{array}{c}\mathbf{Q 4} \\
\text { (Weakest) }\end{array}$ \\
\hline Politically-Connected Firms & $46.7 \%$ & $49.7 \%$ & $51.6 \%$ & $50.7 \%$ & $24.0 \%$ \\
\hline Unconnected Firms & $38.4 \%$ & $45.6 \%$ & $44.4 \%$ & $38.8 \%$ & $29.7 \%$ \\
\hline Difference (Connected-Unconnected) & $8.4 \%$ & $4.1 \%$ & $7.2 \%$ & $12.0 \%$ & $-5.7 \%$ \\
\hline Ratio (Connected/Unconnected) & $121.8 \%$ & $109.0 \%$ & $116.2 \%$ & $130.9 \%$ & $80.7 \%$ \\
\hline $\begin{array}{l}\text { The numbers in this table represent categorice } \\
\text { connected in the first row or unconnected in tl } \\
\text { columns represent categorical means broken } \\
\text { between the first two rows and the ratio betwe } \\
\text { cross-list, and up to some threshold of propert } \\
\text { included in the sample, for this table, it must h }\end{array}$ & $\begin{array}{l}\text { eans of countr } \\
\text { cond row). T } \\
\text { y country-lev }\end{array}$ & lical connec & $\begin{array}{l}\text { 's' cross-lis } \\
\text { to be a ben } \\
\text { tions. The } \\
\text { rns--politic } \\
\text { ippear incr }\end{array}$ & $\begin{array}{l}\text { tivity by fi } \\
\text { k. The sece } \\
\text { vo rows cal } \\
\text { nnected fir } \\
\text { y valuable. }\end{array}$ & $\begin{array}{l}\text { (politically } \\
\text { ough fifth } \\
\text { he difference } \\
\text { more likely t } \\
\text { country to be }\end{array}$ \\
\hline
\end{tabular}


TABLE 3 - Does Being Politically Connected Increase Firms' Probability of Cross-listing?

\begin{tabular}{|c|c|c|c|c|c|}
\hline \multirow{2}{*}{$\begin{array}{l}\text { Dependent Variable: } \\
\text { Politically Connected }\end{array}$} & \multicolumn{5}{|c|}{ Cross List Dummy } \\
\hline & $\begin{array}{l}0.613 * * * \\
(0.119)\end{array}$ & $\begin{array}{c}0.583 * * * \\
(0.123)\end{array}$ & $\begin{array}{l}0.239^{\dagger} \\
(0.156)\end{array}$ & $\begin{array}{c}0.233^{\dagger} \\
(0.157)\end{array}$ & $\begin{array}{l}0.621 * * * \\
(0.118)\end{array}$ \\
\hline \multirow{4}{*}{ Return on Assets } & \multicolumn{5}{|c|}{ Firm Level Controls } \\
\hline & $\begin{array}{l}-0.007 \\
(0.008)\end{array}$ & $\begin{array}{l}-0.001 \\
(0.008)\end{array}$ & $0.687 * * *$ & $0.718^{* * *}$ & \\
\hline & -0.001 & 0.043 & -0.450 & -0.265 & \\
\hline & $(0.038)$ & $(0.040)$ & $(0.520)$ & $(0.433)$ & \\
\hline \multirow[t]{2}{*}{ Capital Intensity } & $-0.476 * * *$ & $-0.473 * * *$ & $-1.084 * * *$ & $-0.660 * * *$ & \\
\hline & $(0.147)$ & $(0.153)$ & $(0.174)$ & $(0.182)$ & \\
\hline \multirow[t]{3}{*}{ Leverage } & 0.588 & 0.497 & -0.256 & -0.208 & \\
\hline & $(0.369)$ & $(0.380)$ & $(0.245)$ & $(0.252)$ & \\
\hline & \multicolumn{5}{|c|}{ Industry Level Controls } \\
\hline \multirow[t]{2}{*}{ Industry Dummies } & No & Yes & No & Yes & No \\
\hline & \multicolumn{5}{|c|}{ Country Level Controls } \\
\hline Country Dummies & No & No & Yes & Yes & No \\
\hline Scenario being Tested: & \multicolumn{5}{|c|}{ Wald Tests (F-Statistics) } \\
\hline Joint Insignificance of Industry Dummies & - & 41.336 & - & 37.654 & - \\
\hline Joint Insignificance of Country Dummies & - & - & 31.928 & 34.237 & - \\
\hline Percentage of Obs. Predicted Correctly & $60.27 \%$ & $64.15 \%$ & $77.82 \%$ & $79.27 \%$ & $60.33 \%$ \\
\hline Number of Observations & 7461 & 7461 & 7461 & 7461 & 7461 \\
\hline \multicolumn{6}{|c|}{$\begin{array}{l}* * \text { represents statistical significance at the } 1 \% \text { level; } * * \text { at the } 5 \% \text { level and } * \text { at the } 10 \% \text { level; } \dagger \text { indicates significance at the } \\
15 \% \text { level for the coefficient on the politically connected dummy variable only. The estimation method for all regressions is logit. } \\
\text { In parentheses below the estimated coefficient values are Huber/White robust standard errors. Columns } 1 \text { and } 5 \text { include a } \\
\text { constant that is not reported. Columns } 1 \text { and } 2 \text { show regressions that pool the data across countries, while Columns } 3 \text { and } 4 \\
\text { show regressions that are within country tests. For the two Wald tests, the null hypotheses are } H_{0}: \gamma_{j}=0 \text { for all } j \text { and } H_{0}: \gamma_{\mathrm{k}}=0 \\
\text { for all k; the null for each of these are strongly rejected in all regressions, meaning that the including the dummy variables has } \\
\text { joint significance at the } 1 \% \text { level. Column } 5 \text { is included as a roubstness check in the spirit of Bertrand et al. (2000) to show that } \\
\text { unobservable firm-level charateristics are unlikely to be driving my results. }\end{array}$} \\
\hline
\end{tabular}




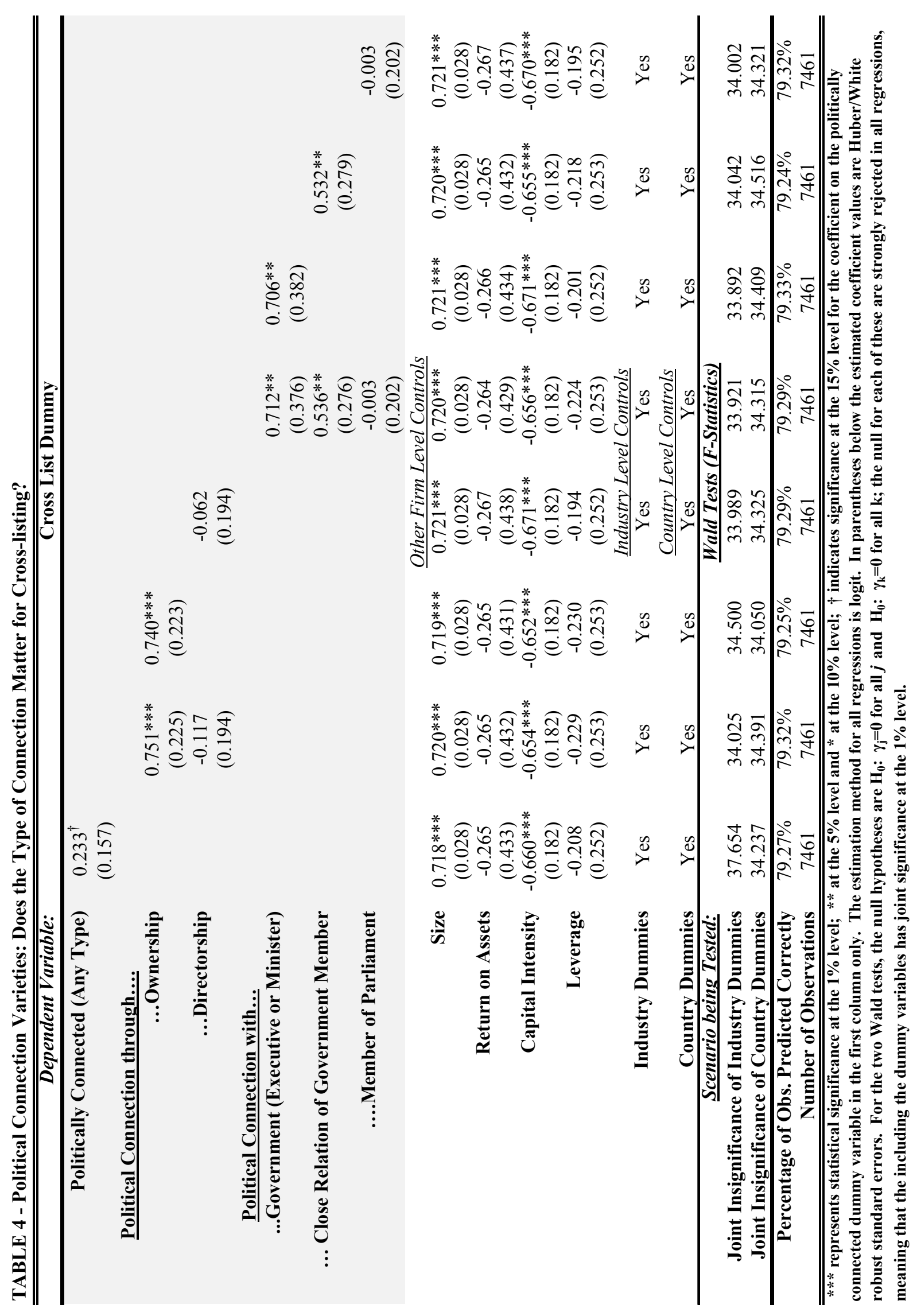


TABLE 5 - How Institutions Affect Firms' Probability of Cross-listing

\begin{tabular}{|c|c|c|c|c|}
\hline \multirow{3}{*}{$\begin{array}{r}\text { Dependent Variable: } \\
\text { Weak Domestic Property Rights }\end{array}$} & \multicolumn{4}{|c|}{ Cross List Dummy } \\
\hline & $-0.627 * *$ & $-0.736 * * *$ & & \\
\hline & $(0.263)$ & $(0.268)$ & & \\
\hline \multirow[t]{3}{*}{ Strong Domestic Contracting } & & & $4.242 * * *$ & $4.146^{* * *}$ \\
\hline & & & $(0.326)$ & $(0.326)$ \\
\hline & \multicolumn{4}{|c|}{ Firm Level Controls } \\
\hline \multirow[t]{2}{*}{ Politically Connected } & & $0.594 * * *$ & & $0.433 * * *$ \\
\hline & & $(0.124)$ & & $(0.131)$ \\
\hline \multirow[t]{2}{*}{ Size } & -0.004 & -0.004 & $0.046 * * *$ & $0.045^{* * *}$ \\
\hline & $(0.008)$ & $(0.008)$ & $(0.009)$ & $(0.009)$ \\
\hline \multirow[t]{2}{*}{ Return on Assets } & 0.043 & 0.044 & 0.041 & 0.040 \\
\hline & $(0.040)$ & $(0.040)$ & $(0.042)$ & $(0.042)$ \\
\hline \multirow[t]{2}{*}{ Capital Intensity } & $-0.450 * * *$ & $-0.437 * *$ & $-0.511 * * *$ & $-0.507 * * *$ \\
\hline & $(0.158)$ & $(0.158)$ & $(0.161)$ & $(0.161)$ \\
\hline \multirow[t]{3}{*}{ Leverage } & 0.577 & 0.543 & 0.488 & 0.467 \\
\hline & $(0.390)$ & $(0.390)$ & $(0.414)$ & $(0.414)$ \\
\hline & \multicolumn{4}{|c|}{$\underline{\text { Industry Level Controls }}$} \\
\hline Industry Dummies & Yes & Yes & Yes & Yes \\
\hline Scenario being Tested: & \multicolumn{4}{|c|}{ Wald Tests (F-Statistics) } \\
\hline Joint Insig. of Ind. Dummies & 40.052 & 39.736 & 36.787 & 36.724 \\
\hline$\%$ of Obs. Predicted Correctly & $64.12 \%$ & $64.31 \%$ & $65.94 \%$ & $66.01 \%$ \\
\hline Number of Observations & 7355 & 7355 & 7191 & 7191 \\
\hline
\end{tabular}

*** represents statistical significance at the $1 \%$ level; $* *$ at the $5 \%$ level and * at the $10 \%$ level. The estimation method for all regressions is logit. In parentheses below the estimated coefficient values are Huber/White robust standard errors. For the Wald test, the null hypotheses is $\mathbf{H}_{0}: \gamma_{j}=0$ for all $j$; the null is strongly rejected in all regressions, meaning that the coefficients are jointly significant. 


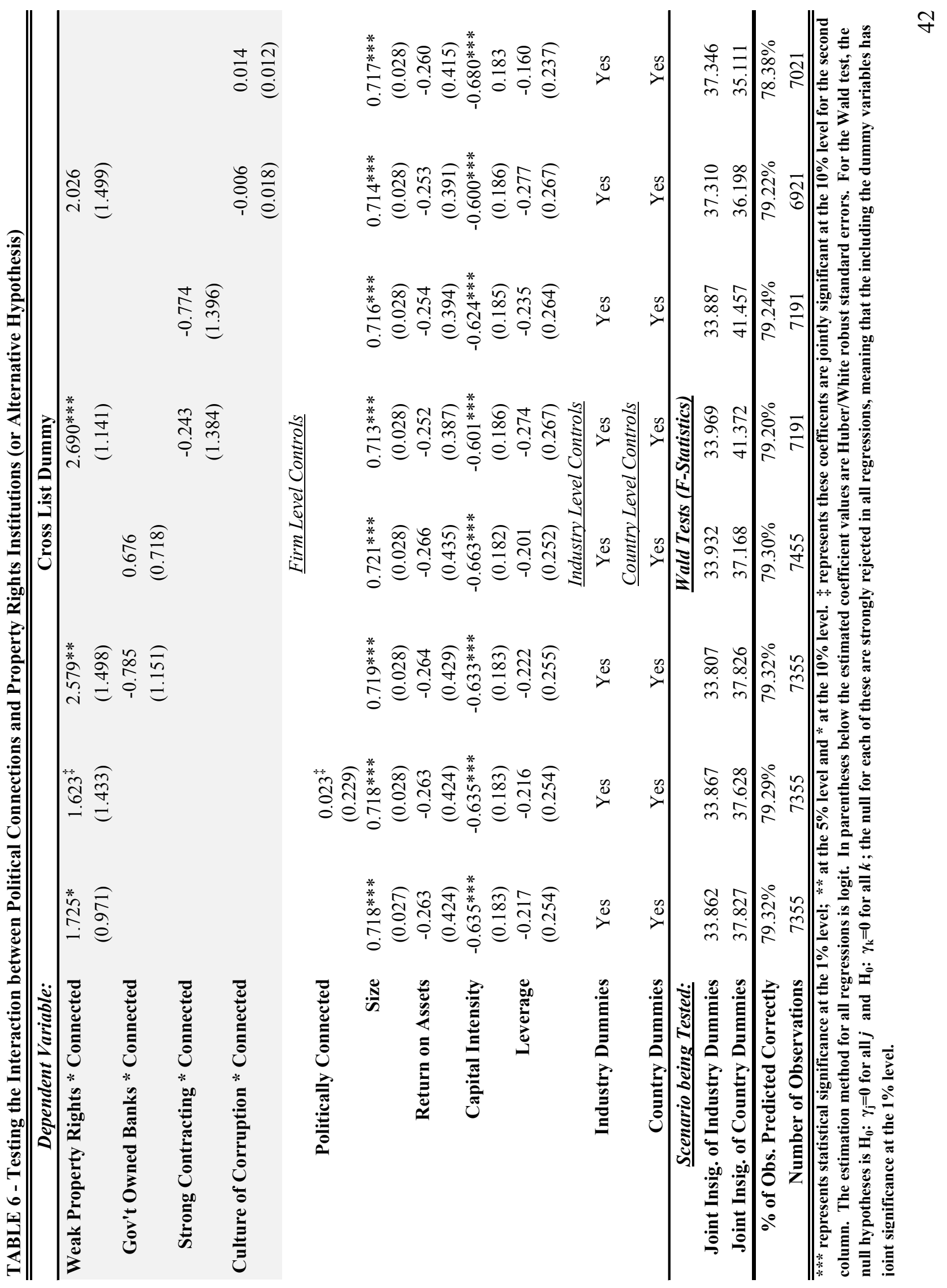


TABLE 7 - Stratified Sample Approach to Connections and Institutions as Joint Determinants

\begin{tabular}{|c|c|c|c|c|}
\hline \multirow{3}{*}{$\begin{array}{r}\text { Dependent Variable: } \\
\text { Sample: }\end{array}$} & \multicolumn{4}{|c|}{ Cross List Dummy } \\
\hline & \multicolumn{4}{|c|}{ Property Rights Institutions' Quartiles (Country-Level) } \\
\hline & $\begin{array}{c}\text { Strongest } \\
(0-25 \%)\end{array}$ & $\begin{array}{c}\text { Moderately Strong } \\
(26-50 \%)\end{array}$ & $\begin{array}{c}\text { Moderately Weak } \\
(51-75 \%)\end{array}$ & $\begin{array}{c}\text { Weakest } \\
\text { (76-100\%) }\end{array}$ \\
\hline \multirow[t]{2}{*}{ Politically Connected } & $\begin{array}{l}-0.224 \\
(0.023)\end{array}$ & $\begin{array}{l}1.056^{* *} \\
(0.452)\end{array}$ & $\begin{array}{c}0.614^{* *} \\
(0.298)\end{array}$ & $\begin{array}{l}-0.086 \\
(0.488)\end{array}$ \\
\hline & \multicolumn{4}{|c|}{ Firm Level Controls } \\
\hline Size & $\begin{array}{c}0.691 * * * \\
(0.032)\end{array}$ & $\begin{array}{c}0.780 * * * \\
(0.057)\end{array}$ & $\begin{array}{c}0.866 * * * \\
(0.083)\end{array}$ & $\begin{array}{c}0.752 * * * \\
(0.138)\end{array}$ \\
\hline Return on Assets & -0.180 & $-1.765^{* * *}$ & -0.855 & $\begin{array}{l}0.702 \\
0.352)\end{array}$ \\
\hline Capital Intensity & $-0.568 * *$ & $-0.865^{*}$ & -0.494 & -0.564 \\
\hline & $(0.251)$ & $(0.448)$ & $(0.413)$ & $(0.701)$ \\
\hline \multirow[t]{3}{*}{ Leverage } & -0.192 & -0.119 & -0.743 & 0.237 \\
\hline & $(0.392)$ & $(0.474)$ & $(0.527)$ & $(0.685)$ \\
\hline & \multicolumn{4}{|c|}{ Industry Level Controls } \\
\hline \multirow[t]{2}{*}{ Industry Fixed Effects } & Yes & Yes & Yes & Yes \\
\hline & \multicolumn{4}{|c|}{ Country Level Controls } \\
\hline Country Fixed Effect & Yes & Yes & Yes & Yes \\
\hline Scenario being Tested: & \multicolumn{4}{|c|}{ Wald Tests (F-Statistics) } \\
\hline Joint Insig. of Ind. Dummies & 39.309 & 22.549 & 17.025 & 4.590 \\
\hline Joint Insig. of Country Dummies & 66.403 & 33.292 & 29.274 & 8.947 \\
\hline$\%$ of Obs. Predicted Correctly & $77.61 \%$ & $79.81 \%$ & $85.80 \%$ & $78.47 \%$ \\
\hline Number of Observations & 4181 & 1258 & 1451 & 367 \\
\hline
\end{tabular}

**** represents statistical significance at the $1 \%$ level; $* *$ at the $5 \%$ level and $*$ at the $10 \%$ level. The estimation method for all regressions is logit. In parentheses below the estimated coefficient values are Huber/White robust standard errors. For the Wald test, the null hypotheses is $H_{0}: \gamma_{j}=0$ for all $j$ and $H_{0}: \gamma_{k}=0$ for all $k$; the null for each of these are strongly rejected in all regressions, meaning that the including the dummy variables has joint significance at the $1 \%$ level. The countries that fall into different quartiles are: for Q1 (the strongest property rights institutions), Austria, Canada, Denmark, Finland, Germany, the Netherlands, New Zealand, Norway, Switzerland, and the United Kingdom; for Q2 (with moderately strong property rights institutions), Australia, Belgium, France, Ireland, Italy, Japan, Singapore, Spain, Sweden, and Taiwan; for Q3 (with moderately weak property rights institutions) Brazil, Chile, Greece, Hong Kong, India, Israel, Malaysia, Mexico, South Korea, and Thailand; and, for Q4 (with the weakest property rights institutions), Argentina, Colombia, Indonesia, Peru, the Philippines, South Africa, Sri Lanka, Turkey, Venezuela, and Zimbabwe. 


\title{
Appendixes for \\ "The Role Political Connections Play in Access to Finance: Evidence from Cross-Listing"
}

\author{
Appendix A - Extended Literature Review \\ Appendix B - Figures Illustrating Three Main Hypotheses \\ Appendix C - Additional Data Displays and Robustness Checks
}




\section{Appendix A - Comprehensive Literature Review}

\section{Choosing an Alternative Financial Home through Cross-listing}

Firms choose not only where to manufacture and sell goods, but also where to finance their operations. ${ }^{1}$ Firm-level and country-level political economy considerations play important roles in both the ability and the willingness of firms to globalize. While we know a lot about the political and country risk factors that influence firms' decisions on where to locate business operations and where to make foreign direct investments, we know much less about the political economy of firms' decisions to finance outside of their traditional home countries. ${ }^{2}$ This makes studying the financial globalization choices of firms a worthwhile departure.

Firms' frequently decide to finance abroad through cross-listing securities on another capital market. ${ }^{3}$ More than $20 \%$ of the securities listed on the New York Stock Exchange (NYSE) in 2004 were for foreign firms. Other popular cross-listing destinations include the largest, deepest, and most efficient capital markets around the world: the NASDAQ in New York, the Deutsche Börse in Frankfurt, the Euronext in Paris, and the London Stock Exchange (LSE). ${ }^{4}$ On the LSE over 50\% of the total value of securities traded in 2004 was derived from foreign firms; on some smaller exchanges, like the one in Switzerland, this number was as high as $93.5 \%{ }^{5}$

The benefits firms can obtain from cross-listing securities are substantial. ${ }^{6}$ They come in various ways. Each effectively increases a firm's market capitalization (Miller 1999). Some of the ways a firm can benefit from cross-listing include: a reduction in the firm's cost of capital (Hail and Leuz 2008); greater equity research analyst coverage/exposure (Baker et al. 2002; Lang et al. 2003; Leuz 2003); increased liquidity of shares (Pagano et al. 2002); a more diverse shareholder base (Aherane et al. 2004; Edison and Warnock 2004; Ammer et al. 2006); and,

\footnotetext{
${ }^{1}$ Desai (2008) contends that there are three important location decisions corporations make in a globalizing world economy; these are for: (1) their "traditional" home(s) for managerial and day-to-day business operations, (2) their legal home(s), and (3) their financial home(s).

${ }^{2}$ On Google Scholar, a recent search for the terms "political economy" and "FDI" returned nearly 40,000 articles, while a search for the term "cross-listing" without also requiring the term "political economy" returned only about 10\% as many articles. For some recent work on this topic see Lee and Mansfield (1996); Dunning (1998); Henisz and Williamson (1999); Henisz (2000); Wei (2000); Henisz and Zelner (2001); Jensen (2003); Henisz (2004); Desai and Moel (2008).

${ }^{3}$ The literature on cross-listings is vast: a simple search for the term "cross-listing" on Google Scholar returns over 4,000 articles. Doidge et al. (2009) suggest the following comprehensive, and analytic, literature reviews as a starting point: Karolyi (1998, 2006), Claessens et al. (2002), and Benos and Weisbach (2004).

${ }^{4}$ While more rare, we also observe a few firms cross-listing their securities on exchanges in emerging markets including those in Argentina, Chile, Malaysia, and the Philippines

${ }^{5}$ All of these facts come from Karolyi (2006); see his Tables 1 and 2 for details on foreign listings on stock exchanges around the world. For a visual representation of the data, see Figures $\mathrm{C} 1 \& \mathrm{C} 2$.

${ }^{6}$ Since the focus of this paper is on the firm, I omit a discussion of the purported benefits to the domestic capital markets of firms choosing to cross-list. Nevertheless, the literature in this area is also quite rich; for more on development resulting from having domestic firms cross-list their securities, see: Hargis (2000), Moel (2001), Claessens et al. (2002), Karolyi (2004), and Levine and Schmukler (2006).
} 
reduced agency conflicts between majority and minority shareholders that increase firms' Tobin's Q value. (Coffee 1999, 2002; Stulz 1999; Doidge et al. 2004; Karolyi 2006).

Despite the potentially substantial benefits, not every firm chooses to cross-list because there are associated costs. Aside from one-time, direct financial costs associated with executing the cross-listing transaction, there are a number of ongoing direct costs involved in maintaining the foreign listing. The higher level of disclosure that attractive cross-listing destinations require necessitates that firms employ a greater number of accountants, lawyers, and auditors in order to maintain a cross-listing. These direct costs of compliance are cited as one of the chief deterrents to cross-listing in a survey of firms conducted by Fanto and Karmel (1997). Disclosure costs are significant for many firms, particularly those from countries where the home country disclosure requirements are most lax. ${ }^{7}$ These direct costs are easier for larger firms to bear since a large portion of the costs associated with cross-listing are fixed, making them more difficult for smaller firms to absorb (Pagano et al. 2002; Doidge et al. 2004).

There may be ongoing indirect costs associated with the stricter disclosure requirements of attractive cross-listing destinations as well. Many firms do not foresee any benefits from disclosing additional information; in other cases, firms do not want to reveal certain information to the public (Licht 2000; Lambert et al. 2007). Chaney et al. (2008) explore a particularly relevant class of firms that often have little to gain from revealing more information: they find cross-country evidence that politically-connected firms prefer not to disclose as much as nonconnected firms.

Beyond the indirect costs of cross-listing, there also appear to be pre-conditions for having a favorable reception by foreign investors. These may deter some firms from attempting to cross-list. Notably larger firms fare better with investors located outside of their traditional homes; this fact holds regardless of whether a firm is cross-listed or whether foreign investors choose to invest directly in securities listed on the domestic financial market in a firm's traditional home (Edison and Warnock 2004).

While there has been substantial inquiry into the costs and benefits of cross-listing, there has been less research into the determinants of firms' decision to cross-list (or not). Firm size is one of the best predictors of whether a firm will choose to cross-list its securities. We should expect this given the dual logic that larger firms are both more attractive to foreign investors and more capable of bearing associated costs.

Coffee $(1999,2002)$ and Stulz (1999) were early proponents of a regulatory bonding theory explaining why some firms choose to cross-list securities. It is one of the most common

\footnotetext{
${ }^{7}$ Following the implementation of the Sarbanes-Oxley Act in July 2002, many firms voluntarily chose to de-list (no maintain their cross-listings) in the United States because the legislation strengthened disclosure requirements. The foreign firms that choose to de-list were either unable or unwilling to respond to this shock to the costs associated with maintaining their foreign financial home in the United States. Many choose to list their securities in London where disclosure requirements were relatively lower following the legislation instead. For more see Doidge et al. (2007); Li (2007), Litvak (2007); and, Zingales (2007)
} 
explanations for why a firm chooses to cross-list securities, other than its size. Doidge et al. (2004) were the first to formalize the regulatory bonding theory building a mathematical model. In essence, the theory states that firms cross-list because they benefit from functionally, and credibly, converging towards having the higher quality contracting institutions (or disclosure requirements) of their cross-listing destination, while maintaining operations in their traditional home. The larger the gap between contracting institutions in a firms' home country and in its cross-listing destination, the greater the potential benefits (Doidge et al. 2004). ${ }^{8}$ There is a large literature attempting to test the regulatory bonding theory. While it finds substantial support, there remain skeptics. ${ }^{9}$

Siegel $(2004,2005)$ introduces the reputational bonding theory as an alternative to explain why the regulatory bonding theory may fail in some instances. The reputational bonding theory is about why some firms choose not to cross-list. Siegel suggests that some firms - those that maintain domestic political connections or those that maintain strategic cross-border alliances - have reputational bonds that they may use to secure similar benefits, at a lower cost domestically, to the ones they would have gained from cross-listing abroad. Proponents of this reputational bonding theory (and its variants) claim that it is a dominant strategy since they expect any associated costs to be lower than those associated with regulatory bonding.

Using evidence from Mexico, Siegel (2004) finds that firms employing reputational bonding (by maintaining strategic cross-border alliances with multinational firms) are less likely to cross-list securities; he suggests these alliances serve as an alternative value creation mechanism since they also ensure quality corporate governance. Leuz and Oberholzer-Gee (2006) use Indonesian data to argue that firms with domestic political connections are less likely to cross-list than their unconnected counterparts. They speculate that politically connected firms have a reduced need to cross-list because the government to which they are tied can pressure banks into giving the connected firms more favorable loan terms than those found in competitive financial markets. Leuz and Oberholzer-Gee (2006) conclude based upon their Indonesian data that the reason they find politically connected firms are less likely to cross-list is because connected firms are the beneficiaries of domestic capital market manipulation.

One limitation of both Seigel's (2004) and Leuz and Oberholzer-Gee's (2006) tests of reputational bonding is that the institutional context is fixed since the tests are run within single countries, rather than across multiple countries; furthermore, economic institutions are relatively weak in both Mexico and Indonesia, where the hypothesis finds its validation. The limitation of testing reputational bonding within a single, fixed institutional context is exposed when Hung et

\footnotetext{
${ }^{8}$ Doidge et al. (2004) not only find empirical support for the idea that the larger the gap is between the quality of contracting institutions at home and in a cross-listing destination are, the greater the benefits will be, but also they write a formal theoretical model explaining why.

${ }^{9}$ Support for the regulatory bonding hypothesis is found by Doidge et al. (2004); Lel and Miller (2008), and Doidge et al. (2009) among others. Doubts about the regulatory bonding hypothesis are cast by Licht (2003); Siegel (2005); Lang et al. (2006).
} 
al. (2008) find that stronger domestic political connections make a firm more, not less, likely to cross-list in the Chinese case. ${ }^{10}$

An integrated approach to the question of what the political economy determinants of cross-listing are — one that simultaneously considers the roles both firm-level and country-level factors play in the decision to cross-list- has yet to be undertaken. In the analytical framework section of the main paper I present a guide to such a study. In it I present three hypotheses that expose the natural tensions between these firm-level and country-level political economy factors in determining whether or not a firm chooses to cross-list. Next, I review important ways in which both domestic political connections and high quality domestic economic institutions create value for firms.

\section{Economic Institutions Set the Rules of the Game}

North (1981) defines, in his seminal work, economic institutions as "the rules of the game in a society" that structure both political and economic exchange. ${ }^{11}$ As Desai (2008) argues, the economic institutions in a firm's traditional home are critically important in its choice to maintain an alternate financial home: in many cases firms may cross-list in an attempt to opt out of certain aspects of their domestic institutional environment.

North's definition of economic institutions can be somewhat difficult to apply to data analyses because in it they are monolithic. In an attempt to clarify what is meant by economic institutions and how we should think about them, Acemoglu and Johnson (2005) follow North's (1981) lead in "unbundling" them. Acemoglu and Johnson assert that there are two varieties of economic institutions - those that apply to contracting and those that apply to property rights. ${ }^{12}$ Acemoglu and Johnson (2005) further claim that property rights institutions should have first order effects on economic outcomes, while contracting institutions play a more minor role.

Acemoglu, Johnson, and Robinson $(2001,2002,2005)$ focus on the role of property rights institutions in determining economic outcomes. They assert that property rights institutions are the fundamental cause of long-run economic growth. ${ }^{13}$ Their primary measure of property rights institutions is the expropriation risk index published in Political Risk Services'

\footnotetext{
${ }^{10}$ Hung, Wong, and Zhang (2008) in a recent working paper suggest that politically connected firms may want to pursue crosslistings because they provide "a mechanism for constraining politicians' pursuit of private benefits and improving efficiency"; they caution, however, that the effectiveness of this mechanisms may be limited if the connections are too strong.

${ }^{11}$ Given that they apply to all firms in a specific location, economic institutions tend to be treated as being constant within a country; hence, they are a country-level variable in most analyses.

${ }^{12}$ A common analytic problem faced in the unbundling institutions is that both property rights institutions and contracting institutions tend to be highly correlated variables across countries. If one is weak, the other also tends to be weak. A visual representation of how commons measures of property rights institutions and contracting institutions (those used by Acemoglu et al., and those used by La Porta, et al.) are correlated across countries can be seen in Figure C5.

${ }^{13}$ While not important to my analysis, the empirical foundations of the claim that property rights institutions are the fundamental cause of economic growth, however, have come under considerable recent attack. For example, see Albouy (2008) who attacks the instrumental variable Acemoglu, Johnson, and Robinson (2001, 2002, 2005) use in their analysis. Glaeser et al. (2004) raise other questions about their argument.
} 
International Country Risk Guide. ${ }^{14}$ The logic is simply that the higher the risk of expropriation, either by the state or other actors in the economy, the weaker are property rights institutions.

In a series of papers on law and finance, La Porta et al. (1998) study the role of contracting institutions, particularly with respect to financial market development. One of their primary measures of contracting institutions is an index of accounting disclosure quality published by the Center for International Financial Analysis and Research; ${ }^{15}$ this measure has also been used extensively in the empirical cross-listings literature, particularly with respect to the regulatory bonding theory. Again, the logic is simply that the higher the quality of accounting disclosures in a particular country, the more transparent are firms' activities, making it easier to write the contracts necessary to borrow or lend capital.

Conceptually, the area where contracting institutions can overlap with property rights institutions can lead to confusion. In practice, contracting institutions tend to refer to rules that require the provision of information enabling contracts to be written; whereas property rights institutions tend to refer to the enforcement of such contracts and protections from outright theft.

While most of the prominent studies on the role of economic institutions focus on macrooutcomes, these institutions also affect firm-level characteristics important to corporate financing options. Laeven and Woodruff (2007) show that optimal firm-size depends critically upon the quality of domestic economic institutions. ${ }^{16}$ Furthermore, it is unclear that every firm actually responds to a given set of formal domestic economic institutions in the same way: this is precisely where political connections to national governments may be important.

\section{Political Influence Can Create Value for Firms in Various Ways}

North (1990) acknowledges that political interactions may be important to how agents can further reduce uncertainty in economic exchange. This may help us reconcile the many findings that those agents who maintain special relationships with institutional stewards (e.g. politically-connected firms) appear to play by slightly different rules within a given institutional context.

Political connections are valuable to the firms that maintain them within the confines of the institutional environment in which they operate. Studies of the value of political connections to firms cover the spectrum of political personalities, ranging from dictators like Hitler (Ferguson and Voth 2008) and Suharto (Fisman 2001, Leuz and Oberholzer-Gee 2006) to democratically elected officials like US senators (Roberts 1990, Jayachandran 2006). ${ }^{17}$

\footnotetext{
${ }^{14}$ A visual representation of the data Acemoglu, Johnson, and Robinson (2001, 2002, 2005) use is available in Figure C3.

${ }^{15}$ A visual representation of the data La Porta et al. (1998) use is available in Figure C4.

${ }^{16}$ Laeven and Woodruff (2007) exploit subtle state-level heterogeneity in the quality of institutions to show that economic institutions are a factor that explains differences in average firm-size across Mexico, in one of the few studies to looks at how institutions matter at a sub-national level.

${ }^{17}$ The benefits of political connections tend to be studied within one country or a fixed institutional context which is a shortcoming of the literature on the value of political connections. The primary reason for this is that it is difficult to have a
} 
Despite the breadth of studies, there are only a few numerical estimates of the explicit value of political connections in different countries in the literature; these tend to be measured in terms of how sensitive the market capitalization of firms are to unexpected changes in the status of political connections. ${ }^{18}$ In Indonesia connections to Suharto were worth an estimated $25 \%$ of the market capitalization of firms (Fisman 2001; Fisman and Miguel 2008). In Italy connections to Giovanni Angelli (Fiat Chairman and Member of Parliament) were worth an estimated 3.4\% of market capitalization (Faccio 2006; Fisman and Miguel 2008). In the United Kingdom, connections to Sir John Moore (Rolls-Royce Chairman and Member of Parliament) were estimated to be worth approximately $0 \%$ (Faccio 2006; Fisman and Miguel 2008); similarly in the U.S., connections to former Vice President Cheney were estimated to be worth approximately $0 \%$ (Fisman et al. 2006). The results of these last two cases - that of the Minister or Parliament in the UK and of the Vice President in the US - are somewhat surprising in that they show that there is no measurable (market) value to firms being politically connected in some contexts despite the widely-held belief that all political connections are inherently valuable. Furthermore, we have no explanation on how and why the value of political connections varies from country to country in the literature; in their recent popular book, Economic Gangsters, Fisman and Miguel (2008) write that this is "a centuries old question."

In an important study, Faccio (2006) collects data on the prevalence of domestic political connections in countries around the world. ${ }^{19}$ She documents the somewhat surprising result that firms with political connections to their national governments are common both in developed and developing countries, despite the popular belief that such connections are most prevalent in the poorest countries with the weakest economic institutions. ${ }^{20}$ Regulations against politicians maintaining ties to firms vary greatly across countries of varying institutional quality and of varying levels of development, explaining Faccio's result. ${ }^{21}$ Indonesia, Italy, and the United Kingdom all fall into the top quartile of countries based on their incidence of political connections; however, the value of political connections in these three countries (in market capitalization terms) varies dramatically from $25 \%$ to $0 \%$. A similarly surprising fact is that in a country with relatively abundant political connections (the United Kingdom), their value can be worth just as little as in a country with relatively scarce connections (the United States).

Preferential access to domestic debt finance is one channel though which politically influential firms receive benefits, possibly through coercion. Studies showing that firms with

comparable definition of political connections across countries. Another reason that political connections tend to be studied within a single country context is that empirical approaches have tended to rely on natural experiments - that shock the connected individuals - for identification.

${ }^{18}$ A visual display of the results from Fisman and Faccio's natural experiment estimates of the value of political connections in terms of market capitalization is available in the Appendix as Figure C7.

${ }^{19}$ A visual display of the incidence of political connections around the world from Faccio (2006) is available in the Appendix as Figure C8.

${ }^{20}$ Figure C9 in the Appendix illustrates in scatterplot form that there is no discernable relationship between the incidence of political connections and the quality of property rights institutions around the world.

${ }^{21}$ Faccio (2006) also collects data on these regulations and creates an index of regulations against political connections around the world. 
political ties obtain better terms on domestic finance in terms of both interest rates charged and amount of credit extended than the population of non-connected firms have been conducted in a number of countries. Those single-country studies include ones on Brazil (Claessens et al. 2008), China (Cull and Xu 2005; Li et al. 2008), Indonesia (Leuz and Oberholzer-Gee 2006), Pakistan (Khwaja and Mian 2005), the Philippines (Hutchcroft 1998), Malaysia (Johnson and Mitton 2003), Thailand (Charumilind et al. 2006), South Korea (Kang 2002), and Vietnam (Malesky and Taussig 2009). ${ }^{22}$ Most of these studies, explain the preferential access to finance influential firms receive by saying coercion of susceptible bankers is the channel; for example, Khwaja and Mian (2005) write "politically powerful firms obtain rents from government banks by exercising their political influence on bank employees." Despite the volume of research on preferential access to domestic debt finance, little is known about whether or not foreign capital markets respond favorably to firms with domestic political connections; given Khwaja and Mian's finding, we would expect foreign capital markets to stay shy of political connected firms.

There are a variety of other ways that political connections can create value for firms too. Political ties can: increase the probability that a firm is the recipient of a government bailout (Faccio et al. 2006); help firms secure favorable regulation or receive government contracts (Agrawal and Knoeber 2001); and, ensure that entities win government appropriations (Roberts 1990; de Figueiredo and Silverman 2006).

Many authors on business ties with politicians see the connections resulting in inefficient allocations of resources at both the micro and macro-levels suggesting that some firms "will benefit at the expense of others" (Kang 2002) and that the existence of political tie-ups "are likely to have an adverse effect on economic growth" (Faccio et al. 2006). These statements stand in opposition to a view that financiers may rationally choose to offer better financing terms to politically connected firms because they are the only firms with the institutional backing required to succeed and that strategic corporate political activity is necessary to mitigate the consequences of operating in weak institutional environments.

\footnotetext{
${ }^{22}$ No cross-country studies have been conducted due to data availability issues; however, Dinc (2004) attempts to get at the question of whether or not government owned banks make more loans around elections in a cross-country study with a very limited sample of banks. A visual representation of the single-country studies can be found in Figure C6
} 


\section{Additional References}

Albouy, D. 2008. "The Colonial Origins of Comparative Development: An Investigation of the Settler Mortality Data." NBER Working Paper \#14130.

Ammer, J.; Holland, S.; Smith, D.; and, Warnock, F. 2006. "Look at Me Now: What Attracts U.S. Shareholders?" NBER Working Paper \#12500.

Ansolbabehere, S.; de Figueiredo, J.; and, Snyder, J. 2003. "Why is There so Little Money in U.S. Politics?” Journal of Economic Perspectives. 17(1), 105-130.

Baker, K.; Nofsinger, J.; and, Weaver, D. 2002. "International cross-listing and Visibility.” Journal of Financial and Quantitative Analysis. 37(3), 495-521.

Benos, E. and Weisbach, M. 2004. "Private benefits and cross-listings in the United States." Emerging Markets Review. 5, 217-240.

Claessens, Stijn, Daniela Klingebiel, and Sergio Schmukler, 2002, The future of stock exchanges in emerging economies: Evolution and prospects, in Robert E. Litan and Richard J. Herring, eds.: Brookings-Wharton Papers on Financial Services 13, 167-202.

Desai, M. 2008. "The Decentering of the Global Firm." World Economy. Forthcoming.

Desai, M. and Moel, A. 2008. "Czech Mate: Expropriation and Investor Protection in a Converging World." Review of Finance 12: 221-251

Doidge, C.; Karolyi, G.; Stulz, R. 2007. "Has New York Become Less Competitive in Global Markets? Evaluating Foreign Listing Choices Over Time" NBER Working Paper \#13079.

Dunning, J. 1998. "Location and the Multinational Enterprise: A Neglected Factor?" Journal of International Business Studies. 29(1), 45-66.

Fanto, J. and Karmel, R. 1997. "A Report on the Attitudes of Foreign Companies Regarding a U.S. Listing," Stanford Journal of Law, Business \& Finance. 3:51

Fisman, D.; Fisman, R.; Galef, J.; and Khurana, R. 2006. "Estimating the value of connections to Vice-President Cheney" Unpublished working paper. [Available online at:

http://www2.gsb.columbia.edu/faculty/rfisman/halliburton_RF27.pdf]

Glaeser, R., La Porta, R., Lopez-de-Salinas, F., Shleifer, A. 2004. "Do Institutions Cause Growth?" Journal of Economic Growth.

Hargis, K. 2000. "International Cross-Listing and Stock Market Development in Emerging Economies." International Review of Economics and Finance 9 (2): 101-22

Henisz, W. and Williamson, O. 1999. "Comparative Economic Organization -- Within and Between Countries." Business and Politics, 1(3): 261-77

Henisz, W. 2004. "Political Institutions and Policy Volatility." Economics \& Politics 16(1): 1-27

Henisz, W. and Zelner, B. 2001. "The Institutional Environment for Telecommunications Investment." Journal of Economics \& Management Strategy, 10(1): 123-47.

Hutchcroft, P. 1998. Booty Capitalism: The Politics of Banking in the Philippines (Cornell University Press, Ithaca and London).

Jayachandran, Seema. 2006. "The Jeffords Effect." Journal of Law \& Economics. 49:2, 397-425.

Appendix (A) - 8 
Jensen, N. 2003. "Democratic governance and multinational corporations: political regimes and inflows of foreign direct investment." International Organization 57, 587-616.

Kang, D. 2002. "Bad Loans to Good Friends: Money Politics and the Developmental State in South Korea.” International Organization 56:1, 177-207.

Karolyi, G. 1998. "Why Do Companies List Shares Abroad? A Survey of the Evidence and its Managerial Implications.” Financial Markets, Institutions \& Instruments 7, New York University Salomon Center.

Karolyi, G. Andrew, 2004, The Role of American Depositary Receipts in the Development of Emerging Markets, The Review of Economics and Statistics, 86(3), 670-690.

Lambert, R.; Leuz, C.; and Verrecchia, R. 2007. "Accounting Information, Disclosure, and the Cost of Capital." Journal of Accounting Research. 45(2), 385-420

Lang, M.; Lins, K.; and, Miller, D. 2003. “ADRs, Analysts, and Accuracy: Does Cross Listing in the United States Improve a Firm's Information Environment and Increase Market Value?" Journal of Accounting Research. 41:317-345.

Lee, J. and Mansfield, E. 1996. "Intellectual property protection and U.S. foreign direct investment." Review of Economics and Statistics 78, 181-186.

Lel, U. and Miller, D. 2008. "International Cross-Listing, Firm Performance, and Top Management Turnover: A Test of the Bonding Hypothesis." J. of Finance 63:4, 1897-1937.

Leuz, C. 2003. "Discussion of ADRs, analysts, and accuracy: does cross-listing in the United States improve a firm's information environment and increase market value?" Journal of Accounting Research. 41:347-362.

Levine, R. and Schmukler, S. 2006. "Internationalization and Stock Market Liquidity.” Review of Finance. 10(1), 153-187

Li, Xi. 2007. "The Sarbanes-Oxley Act and Cross-Listed Foreign Private Issuers." University of Miami Working Paper. [Available online at http://ssrn.com/abstract=952433]

Licht, A. 2000. "Genie in a bottle? Assessing managerial opportunism in international securities transactions." Columbia Business Law Review 2000, 51-120.

Litvak, K. 2007. "The effect of the Sarbanes-Oxley act on non-US companies cross-listed in the US.” Journal of Corporate Finance 13:195-228

Miller, D. 1999. "The market reaction to international cross-listings: Evidence from depositary receipts." Journal of Financial Economics 51, 103-123.

Moel, A. 2001. "The role of ADRs in the development of emerging markets." Economia. 2, 209257.

Wei, S. 2000. "How taxing is corruption on international investors?" Review of Economics and Statistics 82, 1-11.

Zingales, Luigi. 2007. "Is the U.S. Capital market Losing its Competitive Edge?" European Corporate Governance Institute (ECGI) - Finance Working Paper No. 192/2007 


\section{Appendix B - Figures Illustrating Three Main Hypotheses}

Figure B1 - Financing Location Options for both Connected and Unconnected Firms

This figure illustrates the various financing options that both politically connected and unconnected firms can choose from, starting from their traditional home. Firms with domestic political connections (which are represented by the arrows with a circle at the base) can choose among three financing options: (1) financing domestically through normal channels (represented by a loop back to the traditional home); (2) financing abroad by cross-listing in an alternate financial home with higher quality contracting institutions (represented by arrows from the traditional home to the alternative home); or (3) using their connections to coerce domestic bankers (represented by arrows to the shadow behind the traditional home). The firms that are not politically connected (represented by the arrows without a circle at the base) do not have the third option-using back channels since they do not have the political connections required to access this potential source of cheaper finance-although they can choose among either of the first two financing options, depending upon the relative costs and benefits. Whether option (2) or option (3) dominates for politically connected firms across countries is an open empirical question and the subject of Hypothesis 1, which postulates that option (2) dominates option (3). It is also important to note that financing options (1) and (3) are observationally equivalent, since political coercion of bankers cannot be directly observed.

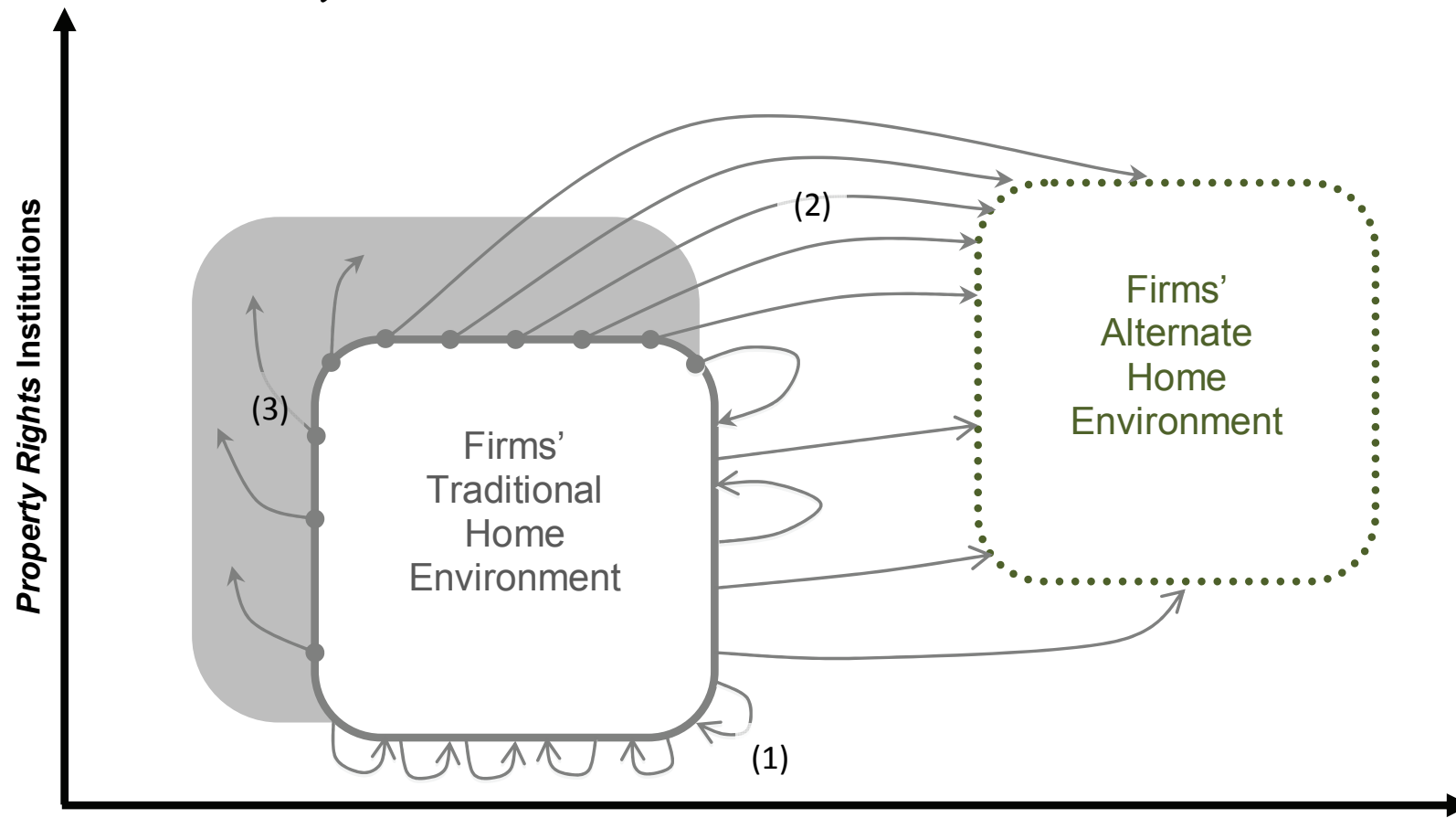

Contracting Institutions

Appendix (B) - 1 
Figure B2 - Cross-listing across Formal Institutional Contexts

This figure provides a visual representation of Hypothesis 2, showing that firms located in countries with the strongest domestic institutions are most likely to cross-list, since on average the costs are lower, even though the benefits (while positive) are also lower. It is largely consistent with results from empirical tests of the regulatory bonding theory run across countries, particularly those in Doidge et al. (2004) who also provide a formal, theoretical/ mathematical model of the regulatory bonding theory. The key difference between the regulatory bonding theory and my depiction is that institutional quality is multidimensional in my conception. Locations (countries) to the top-right of the figure represent those with stronger contracting and stronger property rights institutions; these are the ones that make the most desirable cross-listing destinations since they are where the world's deepest and most efficient financial markets are located. Each arrow-line on the graph represents a firm from the country where the arrow begins choosing to cross-list in the country where the arrow ends. The closer, in the institutions space represented below, a country is to the attractive cross-listing destinations, the easier it is for firms to cross-list securities in them because the costs of compliance with the alternative contracting institutions in institutionally-close destinations are lower; however, the potential benefits are lower too. Benefits can be thought of graphically by the length of the line to a given cross-listing decision.

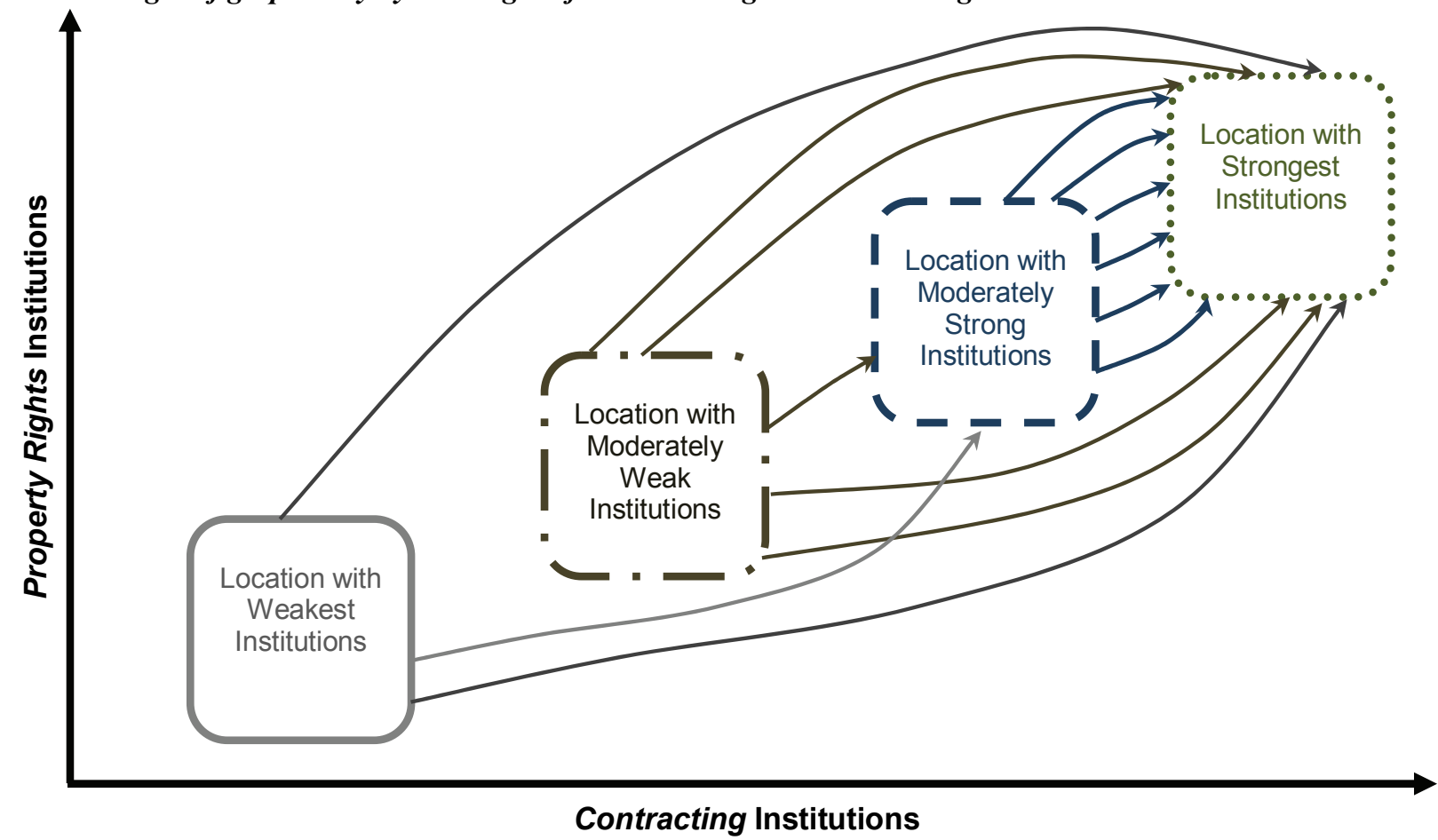

Appendix (B) - 2 
Figure B3 - Financing Location Choices of Firms with Domestic Political Connections across Formal and Implicit Institutional Contexts

This figure illustrates the complexity of Hypothesis 3 by combining all three of the financing possibilities shown in Figure 1 with the various institutional environments shown in Figure 2. The thicknesses of the lines represent how intensively I expect a particular financing choice to be used by firms with domestic political connections for each domestic institutional context. The weaker the formal domestic institutional environment is, the larger the shadow background is that represents the possibility of politicians coercing domestic bankers. Whether or not thicker arrows, representing more intensive financing choices, land in the back-channels (representing informal below market rate domestic financing from coercion of domestic bankers) or in alternative financial homes (representing cross-listings) remains an open empirical question and is the subject of Hypothesis 3. Hypothesis 3 predicts that the arrows representing cross-listing should be thicker than the ones representing coercion of domestic bankers. (Firms without domestic political connections are left out of the figure to keep the figure simple.) As in Figure 1: loops back to the home institutional environment represent financing at home through normal channels; arrows connecting institutional environments represent cross-listing in an alternative institutional environment; and, arrows to the shadows represent back-channel financing at below market rates. As in Figure 2, locations (countries) to the top-right of the figure represent those with stronger formal contracting and property rights institutions.

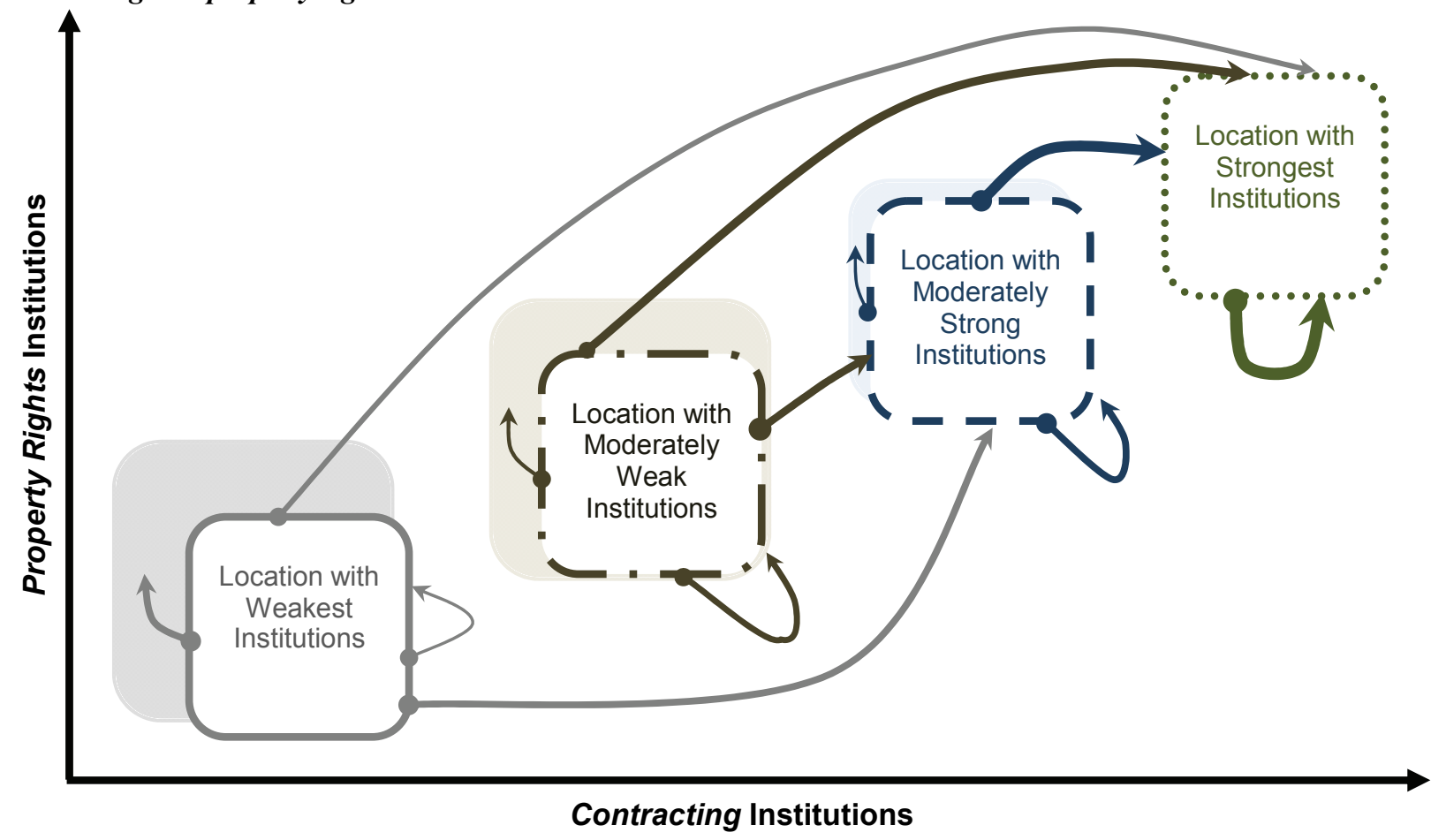

Appendix (B) - 3 


\section{Appendix C - Additional Data Displays and Robustness Checks}

Figure C1- Fraction of Foreign Firms Listed on Equity Markets around the World

This figure illustrates cross-listing destinations around the world. The darker the shading, the higher the fraction of firms listed on a given country's exchange is comprised by foreign firms. For the New York Stock Exchange this number is over 20\%. The underlying data comes from Karolyi's (2006) Table 1.

\section{Cross-listing Destinations - Fraction of Foreign Firms' in Domestic Equity Market} based on Karolyi (2006), Table 1

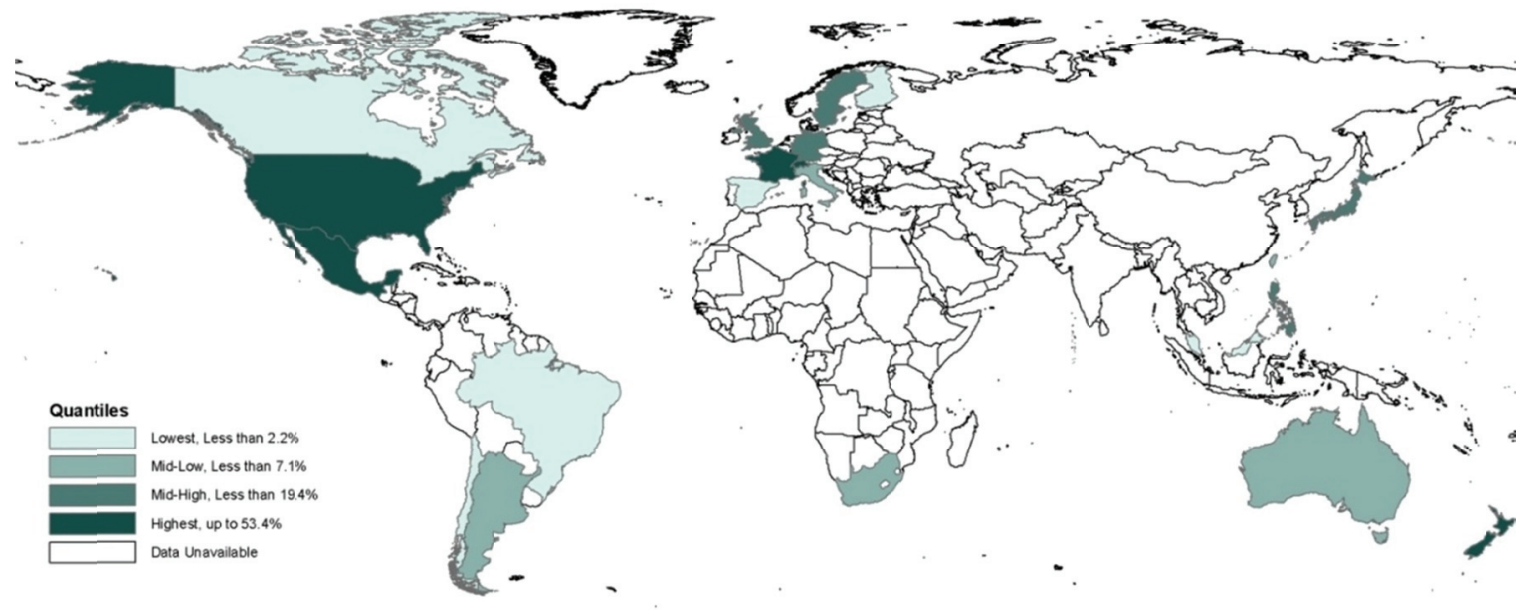

Figure C2- Fraction of Foreign Firms Listed on Equity Markets around the World

This figure illustrates cross-listing destinations around the world. The darker the shading, the higher the fraction of the aggregate market capitalization of a country's stock exchange comes from foreign firms' listings. For the London Stock Exchange this number is over 50\%. In Switzerland it is greater than $90 \%$. The underlying data comes from Karolyi's (2006) Table 2.

Cross-listing Destinations - Fraction of Domestic Market Capitalization from Foreign Firms based on Karolyi (2006), Table 2

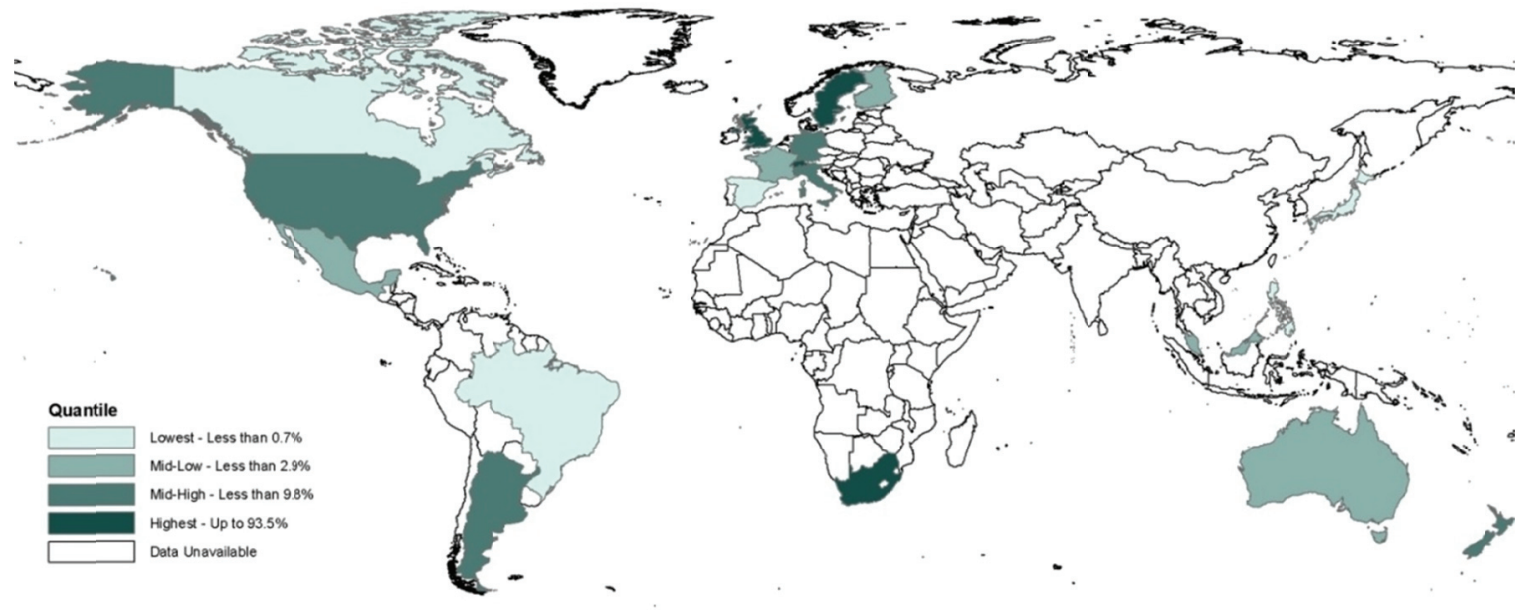

Appendix (C) - 1 
Figure C3- Property Rights Institutions

This figure illustrates how Acemoglu, Johnson, and Robinson's (2001) measure of property rights institutions varies around the world. The darker the shading the weaker the property rights institutions are in a given locale.

\section{Property Rights Insecurity around the World} (based on ICRG Expropriation Index)

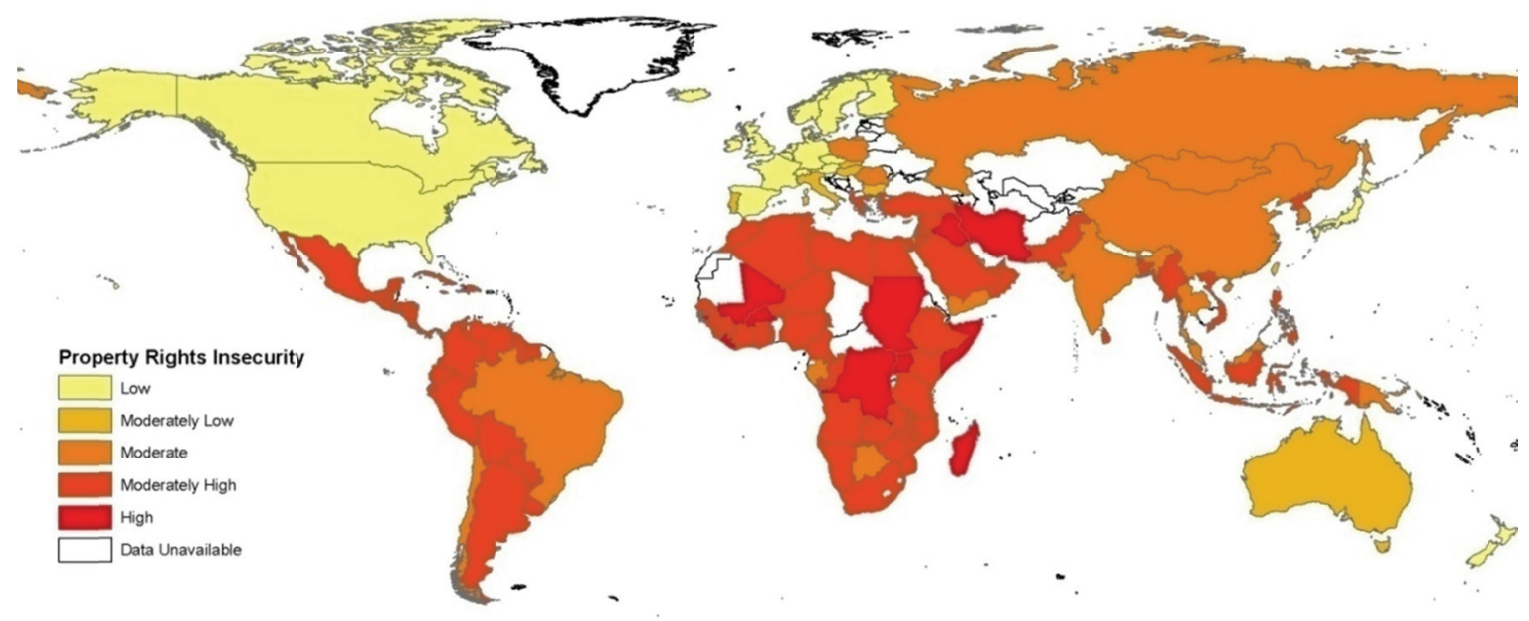

Figure C4- Contracting Institutions

This figure illustrates how La Porta, Lopez-de-Salines, Shleifer, and Vishny's (1998) measure of contracting varies around the world. If the accounting disclosure quality is within $5 \%$ of the level in the United States, the countries are shaded in grey (cross-hatched); if the quality level is greater than that the country is shaded in green (solid); if the disclosure quality is worse than that the country is shaded in red (diagonal stripes).

\section{Contracting Institutions (Accounting Disclosure) around the World} (Accounting Disclosure Quality based on Center for International Financial Analysis \& Research, Inc. Data)

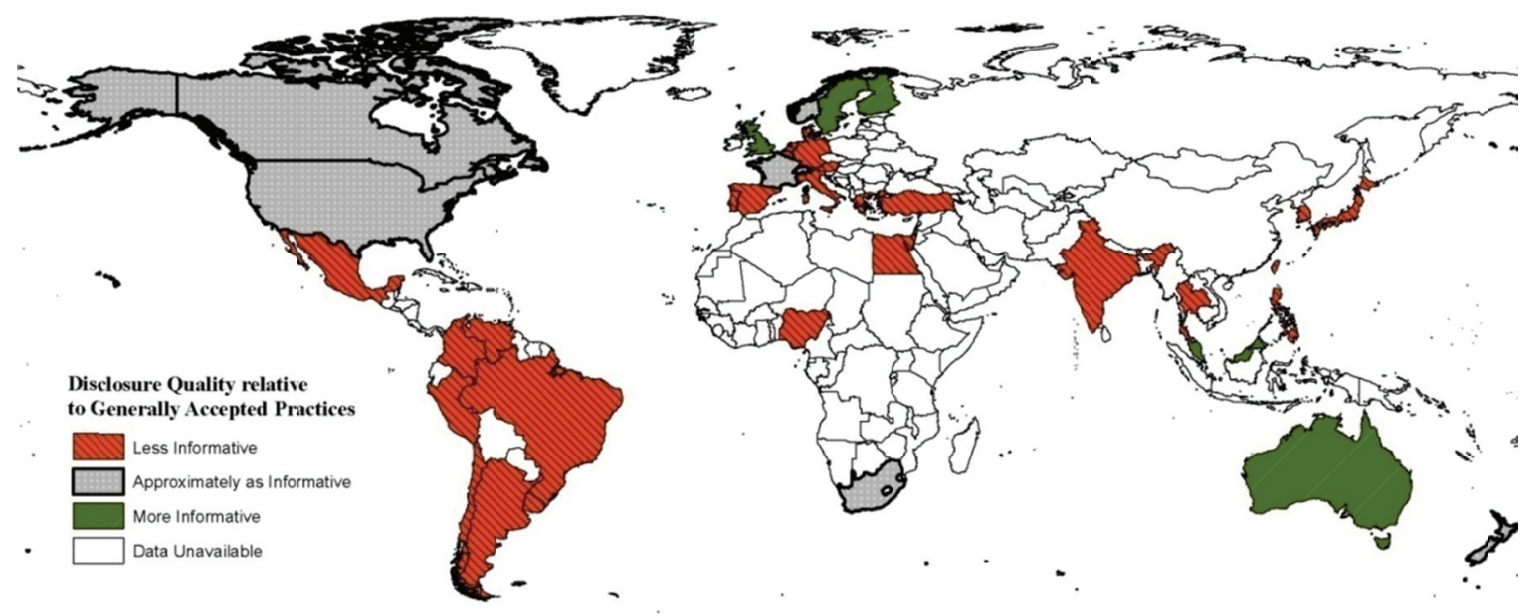

Appendix (C) - 2 
Figure C5- Property Rights vs. Contracting Institutions

This figure illustrates the relationship between property rights institutions and contracting institutions using the same measures as Acemoglu, Johnson, and Robinson (2001) and La Porta, Lopez-de-Salines, Shleifer, and Vishny (1998), for property rights and contracting institutions respectively. Higher values of each represent higher quality institutions in this case.

Property Rights Institutions Quality is Positively Correlated with Contracting Institutions Qualtity

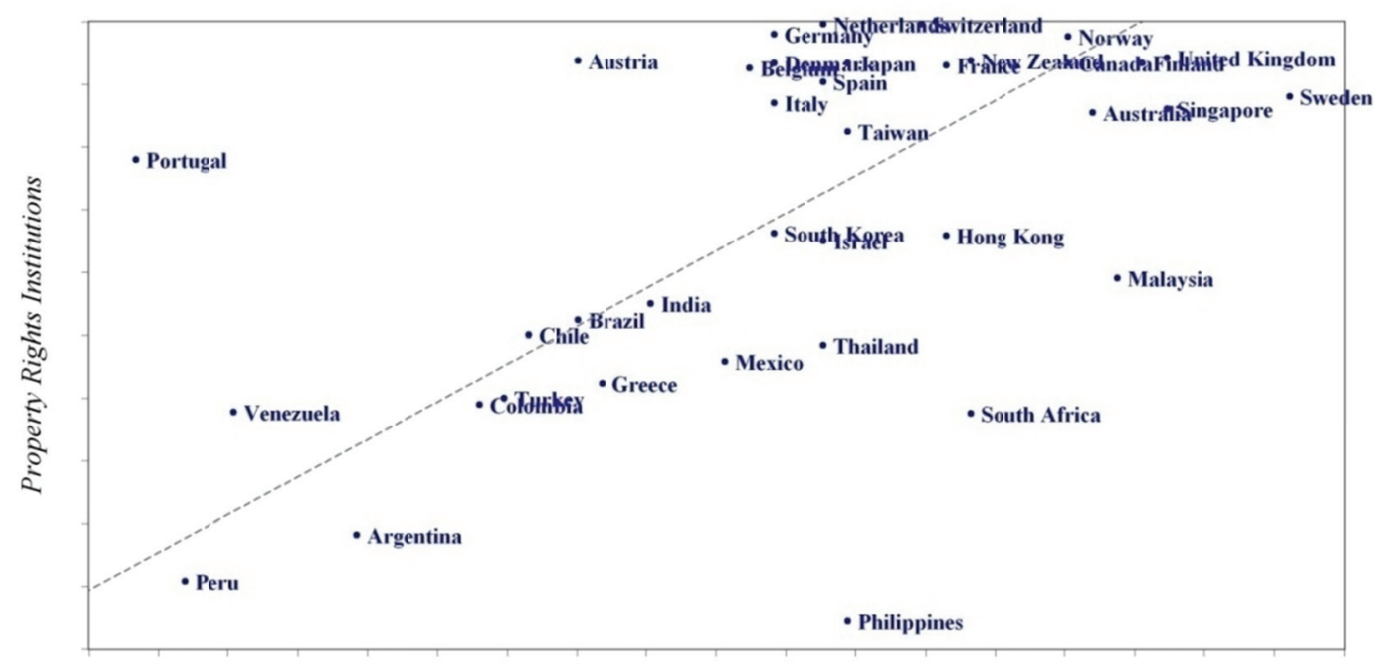

Contracting Institutions

Figure C6- Past Research on Political Influence and Finance, Countries Studied

This figure illustrates various locations in which past researchers find a link between firms' political influence and preferential access to domestic debt financing.

Preferential Terms on Domestic Debt for Politically Linked Firms, Countries Studied (based on various single-country studies)

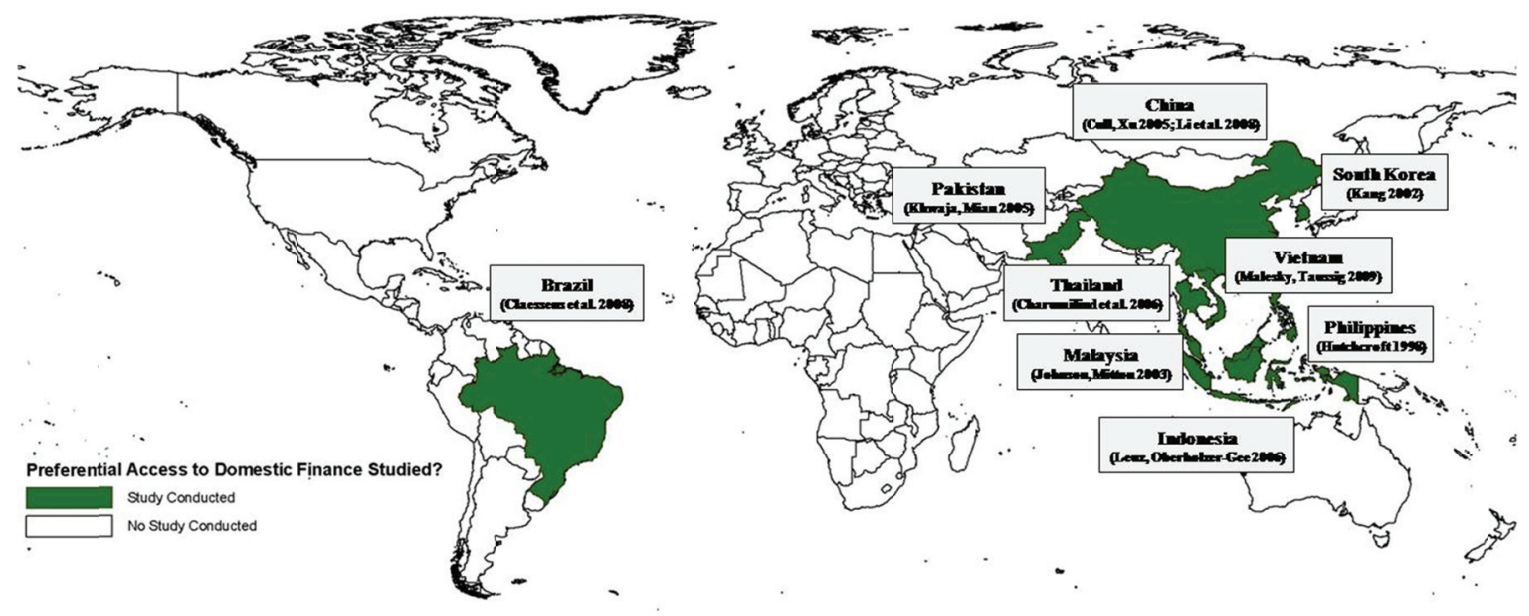

Appendix (C) - 3 
Figure C7- Estimates of the Value of Political Connections around the World

This figure illustrates Fisman's (2001), Faccio's (2006), and Fisman et. al's estimates of the value of political connections around the world. The darker the shading the more valuable the connection is estimated to be; in each of those papers the researchers exploit natural experiments such as health-shocks or surprise-electionoutcomes to estimate the value of political connections as a percentage of a firm's market capitalizations. Fisman, et. al (2001) do this for Dick Cheney, the former United States Vice President affiliated with Halliburton; Faccio (2006) does this for Sir John Moore in the United Kingdom was a member of parliament and Rolls-Royce's chairman; Faccio (2006) also does this for Giovanni Angelli who was a member of the Italian parliament and Fiat's Chairman; Fisman (2001) famously does this for Suharto's many affiliated firms in Indonesia. For more on this research, see Fisman and Miguel's (2008) Economic Gangsters.

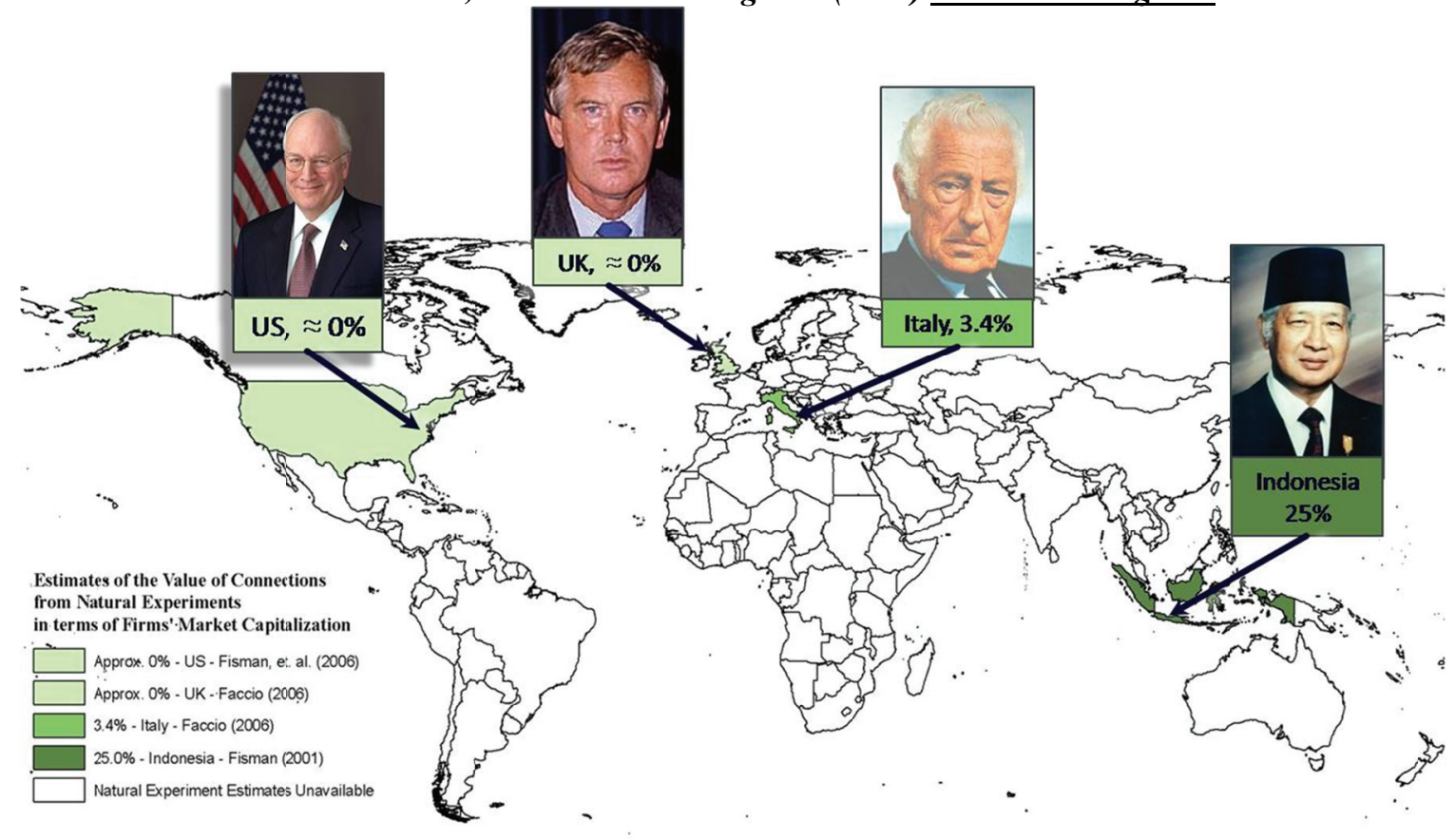

Appendix (C) - 4 
Figure C8- Incidence of Political Connections around the World

This figure illustrates how Faccio's (2006) measure for the incidence of political connections around the world varies across countries. The darker the shading is the higher the fraction of firms in that country is that maintains domestic political connections. A major source of the variance in the underlying data is country specific regulations against political connections. Faccio (2006) finds that political connections are common both in developed and developing countries. In fact, by one of her measures, political connections are most common in the United Kingdom which is also one of the richest countries in the world.

\section{Incidence of Politically Connected Firms around the World}

(Percentage of Politically Connected Firms in the sample, Faccio data)

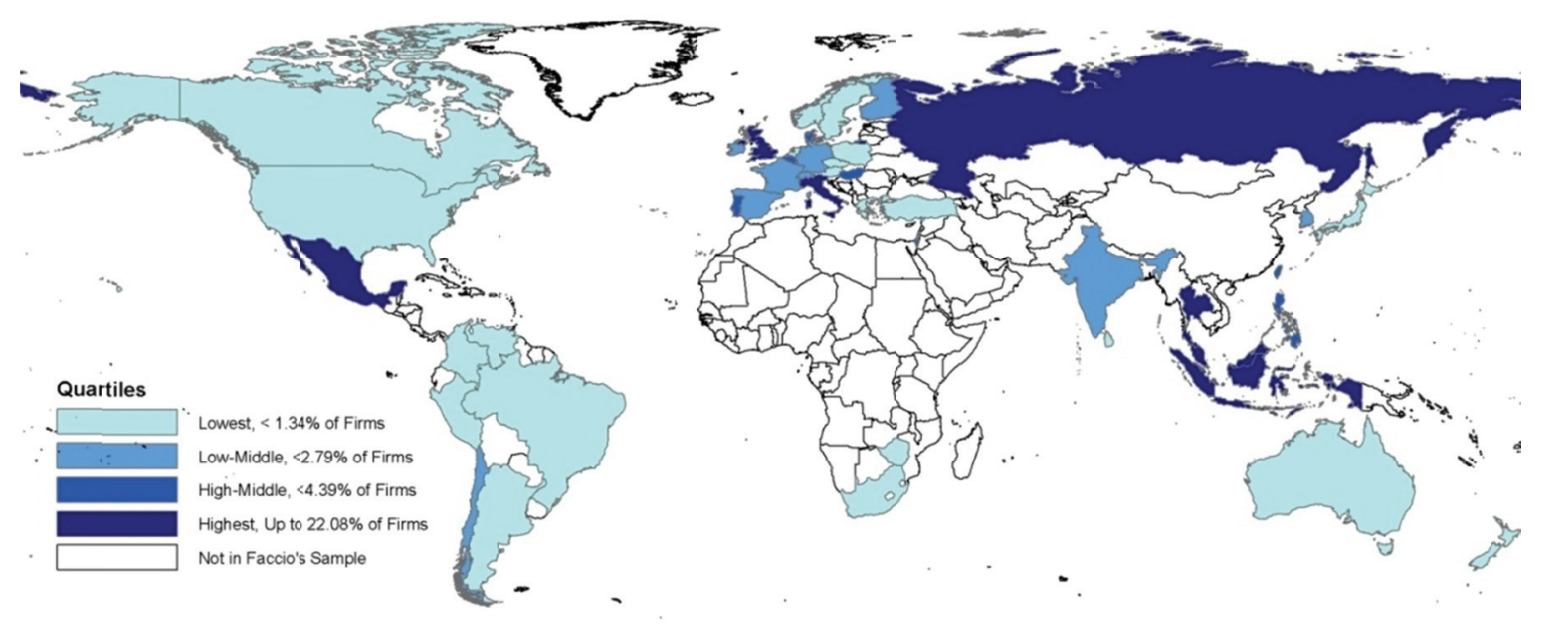

Figure C9 - Scatterplot of Property Rights Institutions vs. Incidence of Political Connections

This figure illustrates the lack of any relationship between the incidence of political connections around the world (Faccio 2006) and the quality of property rights institutions. It is a surprise to many people that there is not a stronger correlation or pattern. Part of the reason there might not be a relationship is that regulations against politicians maintaining political ties abound and are apparently randomly disturbed across countries.

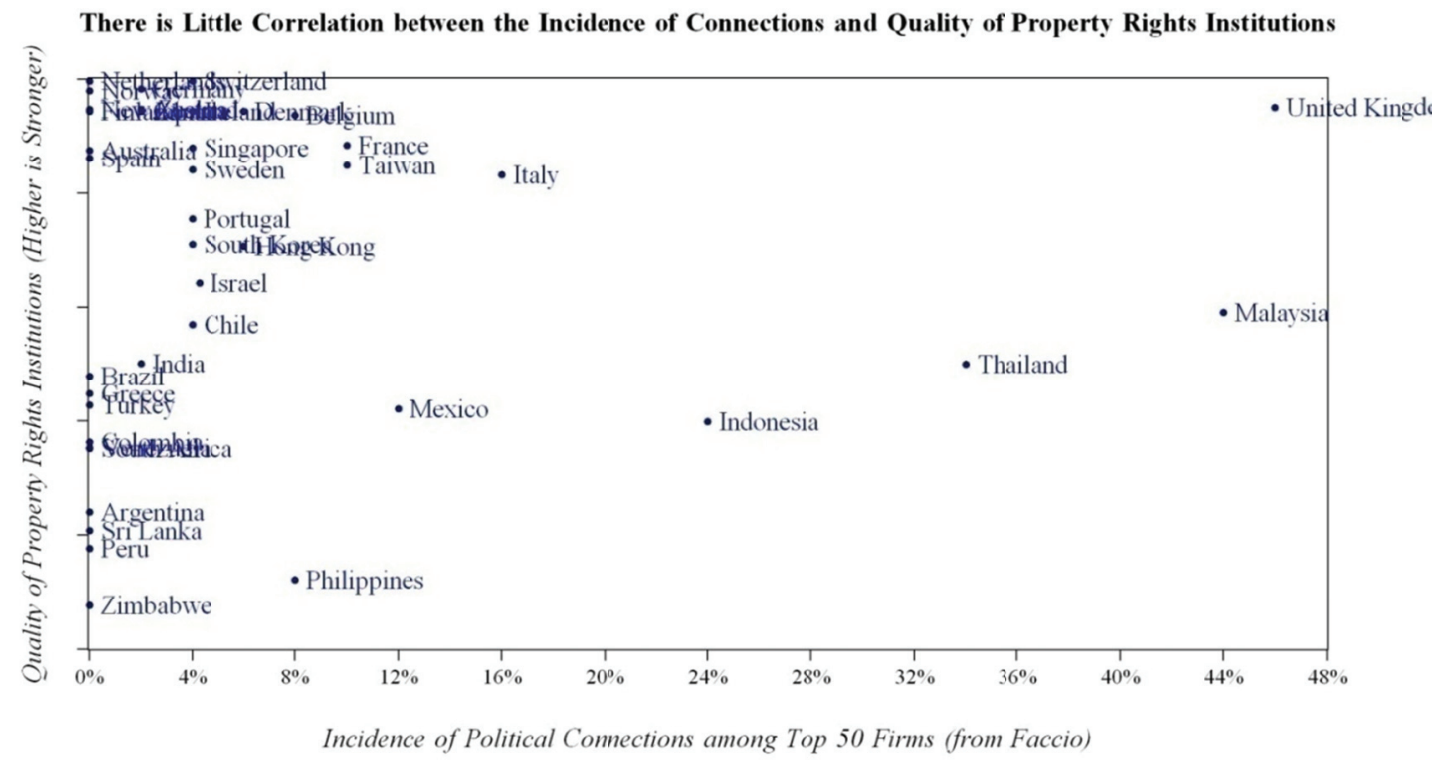

Appendix (C) - 5 
Figure C10 - Politically-connected vs. Unconnected Firm-level Summary Statistics

The following box plots illustrate the summary statistics for the key firm-level variables by political connection status, across countries. The edges of the box represent the $25 \%$ quartile and the $75 \%$ quartile; the solid line through the middle of the box represents the median; the solid black square represents the mean; the whiskers extend out to plus/minus two standard deviations from the mean; and, dots represent outliers.

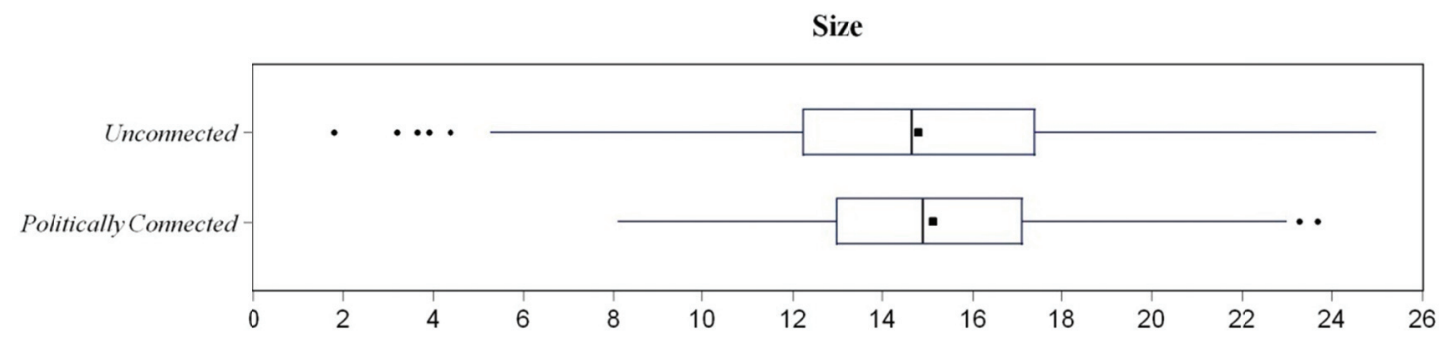

Leverage

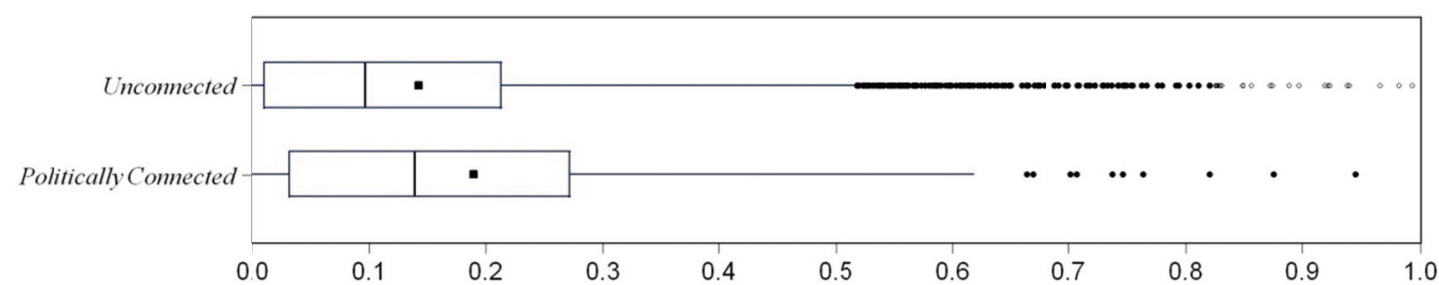

Capital Intensity

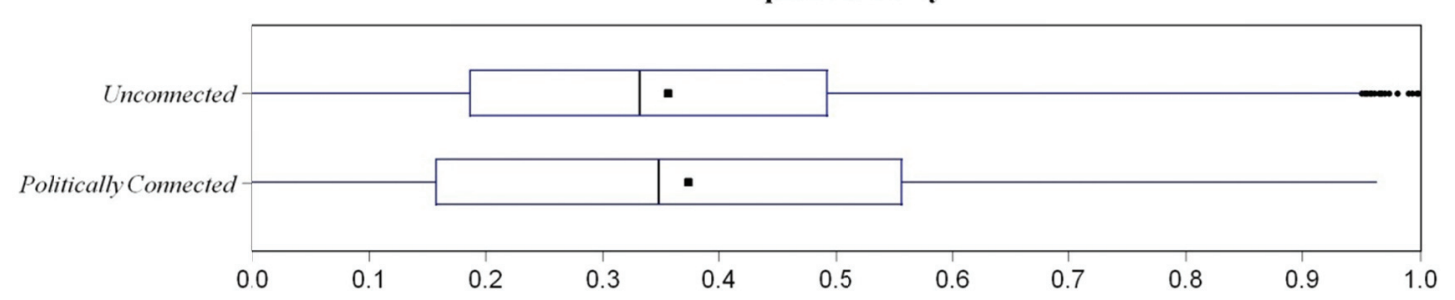

Return on Assets

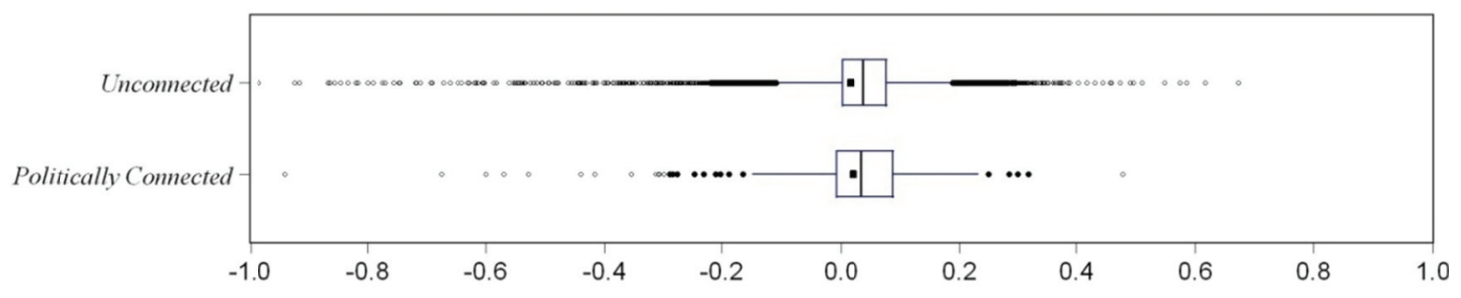

Appendix (C) - 6 


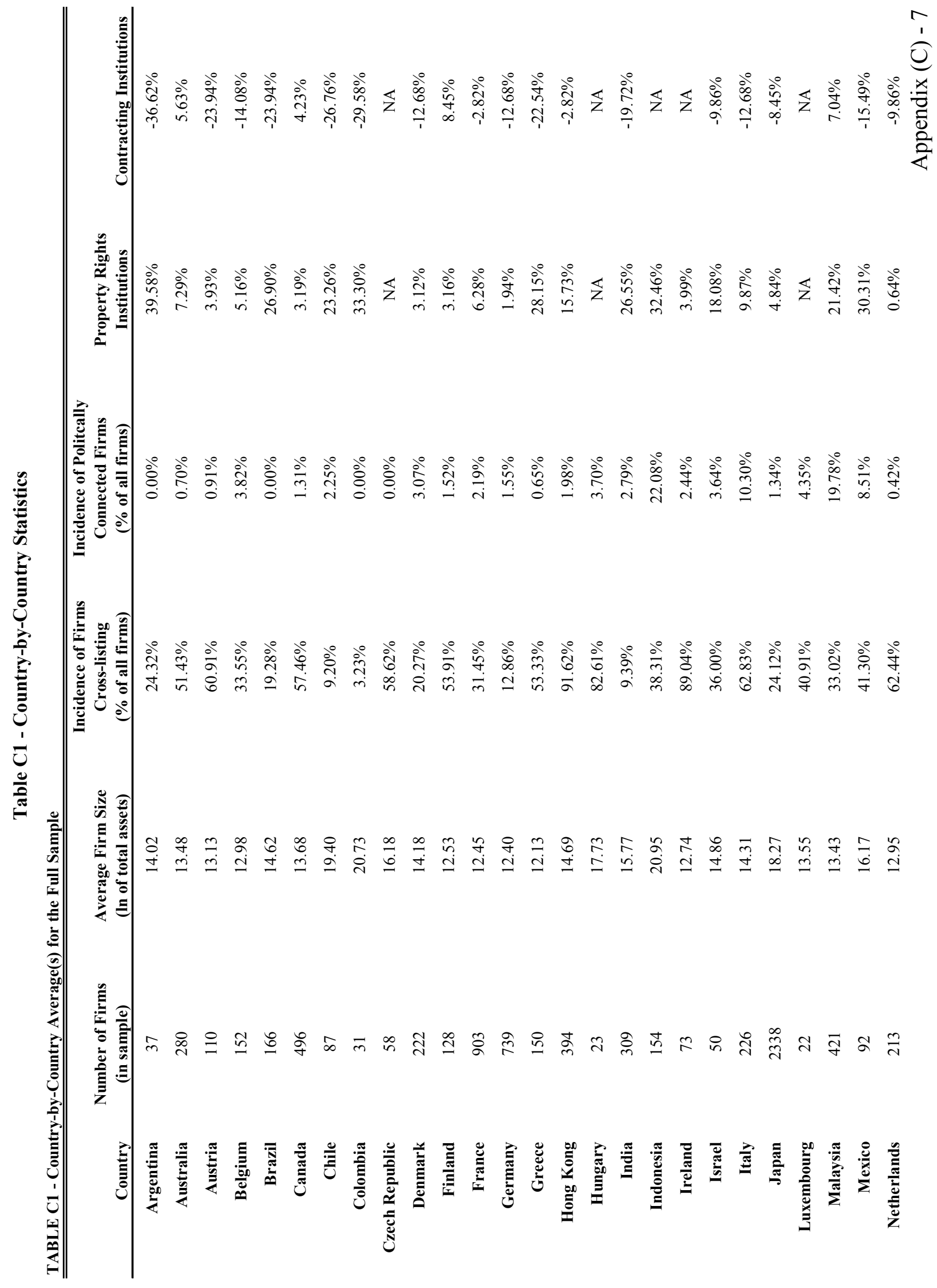




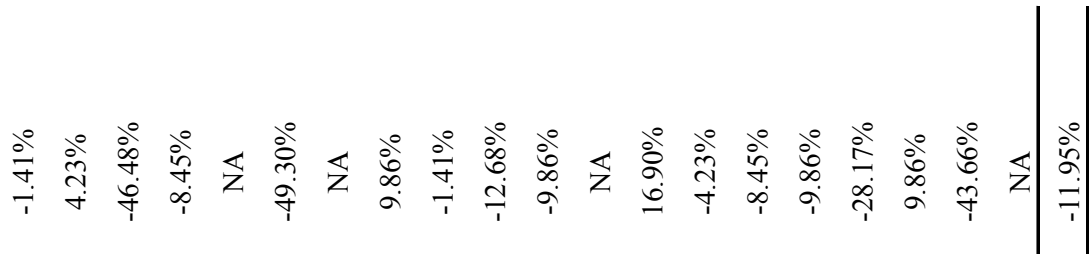

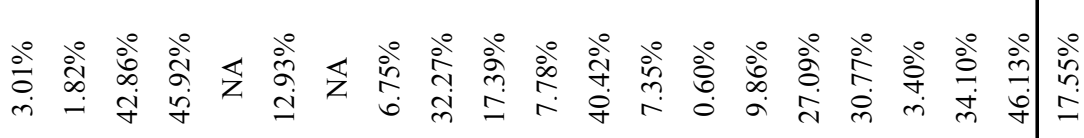

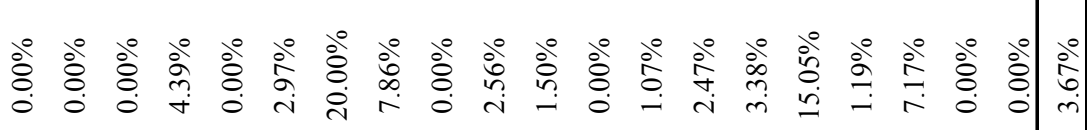

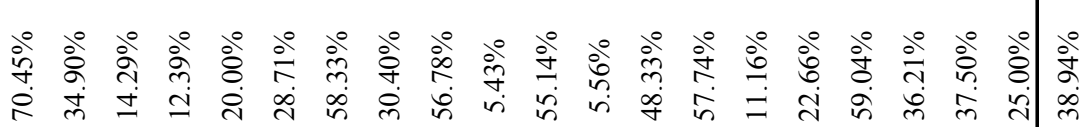

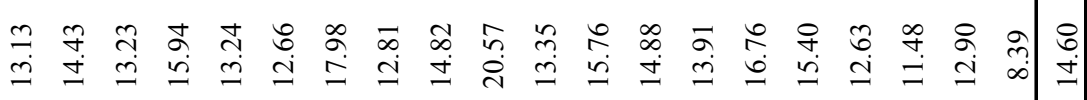

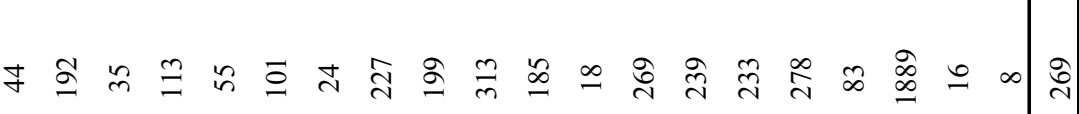

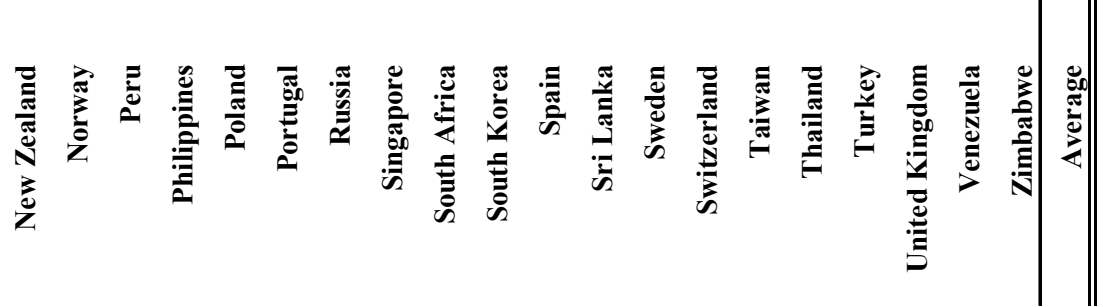

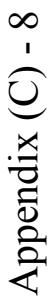


Table C2 - Firm-level Correlation Matrix

The following table contains the correlation matrix for the firm-level variables used throughout my analysis.

TABLE C2 - Firm Level Correlation Matrix

\begin{tabular}{|c|c|c|c|c|c|}
\hline Politically Connected & $\begin{array}{c}\text { Politically } \\
\text { Connected } \\
1.000\end{array}$ & Size & $\begin{array}{c}\text { Return on } \\
\text { Assets }\end{array}$ & $\begin{array}{c}\text { Capital } \\
\text { Intensity }\end{array}$ & Leverage \\
\hline Size & 0.021 & 1.000 & & & \\
\hline Return on Assets & 0.001 & 0.112 & 1.000 & & \\
\hline Capital Intensity & 0.015 & 0.135 & 0.043 & 1.000 & \\
\hline Leverage & 0.039 & 0.084 & -0.011 & 0.219 & 1.000 \\
\hline
\end{tabular}

Table C3 - Industry-by-Industry Statistics for Cross-listing/Political Connections

TABLE C3 - Industry-by-Industry Average(s) for the Full Sample

\begin{tabular}{rcccc}
\hline \hline Country & $\begin{array}{c}\text { Number of Firms } \\
\text { (in sample) }\end{array}$ & $\begin{array}{c}\text { Average Firm Size } \\
\text { (ln of total assets) }\end{array}$ & $\begin{array}{c}\text { Incidence of Firms } \\
\text { Cross-listing } \\
\text { (\% of all firms) }\end{array}$ & $\begin{array}{c}\text { Incidence of Politcally } \\
\text { Connected Firms } \\
\text { (\% of all firms) }\end{array}$ \\
\hline Basic Materials & 1235 & 15.4 & $35.6 \%$ & $3.2 \%$ \\
Consumer Goods & 2155 & 14.8 & $27.3 \%$ & $2.3 \%$ \\
Consumer Services & 1429 & 14.4 & $36.0 \%$ & $5.5 \%$ \\
Financials & 2084 & 15.5 & $35.2 \%$ & $5.1 \%$ \\
Health Care & 357 & 14.2 & $54.9 \%$ & $3.1 \%$ \\
Industrials & 3219 & 14.9 & $29.3 \%$ & $4.0 \%$ \\
Oil \& Gas & 257 & 14.9 & $57.6 \%$ & $5.8 \%$ \\
Technology & 592 & 13.7 & $59.1 \%$ & $2.7 \%$ \\
Telecommunications & 139 & 16.4 & $67.6 \%$ & $7.2 \%$ \\
Utilities & 245 & 16.2 & $43.7 \%$ & $4.5 \%$ \\
\hline All & 11712 & 14.9 & $35.1 \%$ & $4.0 \%$ \\
\hline \hline
\end{tabular}

Appendix (C) - 9 
Table C4 - Size Measure Robustness Checks for Direct Effect of Political Connections Regressions As a robustness check, this table presents regressions using alternative size metrics, rather than the standard log(Total Assets) used throughout the paper. This should help alleviate concerns that log(Total Assets) does not adequately control for firm size. Total Assets and Total Assets squared should emphasize the larger firms even more rather than normalizing the data through a log transformation. Note that the coefficient on the political connections variable and its statistical significance becomes larger when these are included.

TABLE C4 - Size Robustness Checks -- Does being politically increase the probability of cross-listing?

\begin{tabular}{|c|c|c|c|c|}
\hline \multirow{2}{*}{$\begin{array}{l}\text { Dependent Variable: } \\
\text { Politically Connected }\end{array}$} & \multicolumn{4}{|c|}{ Cross List Dummy } \\
\hline & $\begin{array}{l}0.233^{\dagger} \\
(0.157)\end{array}$ & $\begin{array}{c}0.718^{* * * *} \\
(0.135)\end{array}$ & $\begin{array}{c}0.687 * * * \\
(0.130)\end{array}$ & $\begin{array}{l}0.253 * \\
(0.134)\end{array}$ \\
\hline & \multicolumn{4}{|c|}{ Firm Size Control Variable(s) } \\
\hline $\log ($ Total Assets) & $\begin{array}{l}0.718^{* * *} \\
(0.028)\end{array}$ & \multirow{3}{*}{$\begin{array}{l}0.000 * * \\
(0.000)\end{array}$} & & $\begin{array}{c}0.471 * * * \\
(0.019)\end{array}$ \\
\hline Total Assets & & & & $\begin{array}{c}0.000 * * * \\
(0.000)\end{array}$ \\
\hline (Total Assets) $^{2}$ & & & $\begin{array}{c}0.000 \\
(0.000)\end{array}$ & $\begin{array}{c}0.000 * * * \\
(0.000)\end{array}$ \\
\hline & \multicolumn{4}{|c|}{ Other Firm Level Controls } \\
\hline Return on Assets & $\begin{array}{l}-0.265 \\
(0.433)\end{array}$ & $\begin{array}{l}0.085^{*} \\
(0.050)\end{array}$ & $\begin{array}{l}0.068^{*} \\
(0.041)\end{array}$ & $\begin{array}{l}-0.132 \\
(0.118)\end{array}$ \\
\hline Capital Intensity & $\begin{array}{c}-0.660 * * * \\
(0.182)\end{array}$ & $\begin{array}{c}-0.426 * * * \\
(0.149)\end{array}$ & $\begin{array}{l}-0.269 \\
(0.167)\end{array}$ & $\begin{array}{c}-0.492 * * * \\
(0.142)\end{array}$ \\
\hline \multirow[t]{2}{*}{ Leverage } & $\begin{array}{l}-0.208 \\
(0.252)\end{array}$ & $\begin{array}{c}0.547 * * * \\
(0.186)\end{array}$ & $\begin{array}{c}0.376 \\
(0.409)\end{array}$ & $\begin{array}{c}0.071 \\
(0.149)\end{array}$ \\
\hline & \multicolumn{4}{|c|}{ Industry Level Controls } \\
\hline Industry Dummies & \multicolumn{4}{|c|}{ Country Level Controls } \\
\hline Country Dummies & Yes & Yes & Yes & Yes \\
\hline Scenario being Tested: & \multicolumn{4}{|c|}{ Wald Tests (F-Statistics) } \\
\hline Joint Insignificance of Industry Dummies & 37.654 & 39.918 & 36.635 & 30.310 \\
\hline Joint Insignificance of Country Dummies & 34.237 & 22.606 & 32.575 & 49.555 \\
\hline $\begin{array}{r}\text { Percentage of Obs. Predicted Correctly } \\
\text { Number of Observations }\end{array}$ & $\begin{array}{c}79.27 \% \\
7461\end{array}$ & $\begin{array}{c}75.49 \% \\
7461\end{array}$ & $\begin{array}{c}74.31 \% \\
7461\end{array}$ & $\begin{array}{c}79.82 \% \\
7461\end{array}$ \\
\hline
\end{tabular}

$* * *$ represents statistical significance at the $1 \%$ level; $* *$ at the $5 \%$ level and $*$ at the $10 \%$ level; $\dagger$ indicates significance at the $15 \%$ level for the coefficient on the politically connected dummy variable only. The estimation method for all regressions is logit. In parentheses below the estimated coefficient values are Huber/White robust standard errors. Column 1 replicates Column 4 of the Table 3 in the body of the paper, which tests Hypothesis 1 . The results with alternative size measures empasizing larger firms in Columns 2-4 show that the significance of the politically connected firm indicator actually become stronger when they are used. For the two Wald tests, the null hypotheses are $\mathrm{H}_{0}: \gamma_{\mathrm{j}}=0$ for all $j$ and $\mathrm{H}_{0}: \gamma_{\mathrm{k}}=0$ for all $\mathrm{k}$; the null for each of these are strongly rejected in all regressions, meaning that the including the dummy variables has joint significance at the $1 \%$ level. 
Table C5 - Attempting to Unpack the Country Dummy Variables in the Multilevel Regressions

This table of regressions attempts to 'unpack' what is in the country dummy variable in the multi-level regression framework beyond contracting and property rights institutions. See Section 4.2 of the paper for a discussion of the challenges in assessing the importance of these additional co-variates.

TABLE C5 - 'Unpacking' the Country Dummy in the Multi-level Regression

\begin{tabular}{|c|c|c|c|c|c|c|}
\hline \multirow{2}{*}{$\begin{array}{l}\text { Dependent Variable: } \\
\text { Weak Property Rights }\end{array}$} & \multicolumn{6}{|c|}{ Cross List Dummy } \\
\hline & $\begin{array}{c}-6.551 * * * \\
(0.448)\end{array}$ & $\begin{array}{c}-1.466 * * * \\
(0.509)\end{array}$ & $\begin{array}{c}-6.468 * * * \\
(0.512)\end{array}$ & $\begin{array}{c}-6.815 * * * \\
(0.877)\end{array}$ & $\begin{array}{c}-5.124 * * * \\
(0.929)\end{array}$ & $\begin{array}{c}-6.662 * * * \\
(0.963)\end{array}$ \\
\hline Strong Contracting & $\begin{array}{c}1.154 * * * \\
(0.420)\end{array}$ & $\begin{array}{c}4.347 * * * \\
(0.377)\end{array}$ & $\begin{array}{l}1.88 * * * \\
(0.444)\end{array}$ & $\begin{array}{c}4.044 * * * \\
(0.359)\end{array}$ & $\begin{array}{c}6.839 * * * \\
(0.526)\end{array}$ & $\begin{array}{c}3.695 * * * \\
(0.737)\end{array}$ \\
\hline Legal Origin, UK & $\begin{array}{c}0.689 * * * \\
(0.117)\end{array}$ & & $\begin{array}{c}0.436^{* * *} \\
(0.117)\end{array}$ & & & $\begin{array}{c}2.198 * * * \\
\quad(0.33)\end{array}$ \\
\hline Legal Origin, France & $\begin{array}{c}0.784 * * * \\
(0.141)\end{array}$ & & $\begin{array}{c}0.883 * * * \\
(0.139)\end{array}$ & & & $\begin{array}{c}2.692 * * * \\
(0.613)\end{array}$ \\
\hline Legal Origin, Germany & $\begin{array}{c}-2.224 * * * \\
(0.141)\end{array}$ & & $\begin{array}{c}-1.989 * * * \\
(0.142)\end{array}$ & & & $\begin{array}{c}0.100 \\
(0.388)\end{array}$ \\
\hline Dip Parking Tix (FM) & & $\begin{array}{l}0.034 * * * \\
(0.003)\end{array}$ & $\begin{array}{c}0.002 \\
(0.007)\end{array}$ & & & $\begin{array}{l}0.016 * \\
(0.010)\end{array}$ \\
\hline Trust Neighbors (WVS) & & & & $\begin{array}{c}1.346 * * * \\
(0.317)\end{array}$ & $\begin{array}{l}2.42 * * * \\
(0.477)\end{array}$ & $\begin{array}{l}0.939 * \\
(0.632)\end{array}$ \\
\hline Religion Important (WVS) & & & & $\begin{array}{c}3.677 * * * \\
(0.363)\end{array}$ & $\begin{array}{c}2.607 * * * \\
(0.376)\end{array}$ & $\begin{array}{c}0.591 \\
(0.503)\end{array}$ \\
\hline Politics Important (WVS) & & & & $\begin{array}{c}-4.545 * * * \\
(0.361)\end{array}$ & $\begin{array}{c}-3.235 * * * \\
(0.425)\end{array}$ & $\begin{array}{l}-0.818^{*} \\
(0.561)\end{array}$ \\
\hline Muslim \% & & & & & $\begin{array}{c}0.035 * * * \\
(0.004)\end{array}$ & $\begin{array}{c}0.029 * * * \\
(0.007)\end{array}$ \\
\hline Catholic \% & & & & & $\begin{array}{c}0.020 * * * \\
(0.002)\end{array}$ & $\begin{array}{l}0.007 * \\
(0.006)\end{array}$ \\
\hline Protesant \% & & & & & $\begin{array}{c}0.005 * * * \\
(0.002)\end{array}$ & $\begin{array}{c}0.028 * * * \\
(0.003)\end{array}$ \\
\hline & \multicolumn{6}{|c|}{ Firm Level Controls } \\
\hline Politically Connected & $\begin{array}{c}0.236 * * \\
(0.136)\end{array}$ & $\begin{array}{c}0.533 * * * \\
(0.132)\end{array}$ & $\begin{array}{c}0.388 * * * \\
(0.135)\end{array}$ & $\begin{array}{c}0.243^{*} \\
(0.158)\end{array}$ & $\begin{array}{c}0.280 * * \\
(0.153)\end{array}$ & $\begin{array}{l}0.233^{*} \\
(0.159)\end{array}$ \\
\hline Size & $\begin{array}{c}0.305 * * * \\
(0.017)\end{array}$ & $\begin{array}{c}0.060 * * * \\
(0.136)\end{array}$ & $\begin{array}{c}0.281 * * * \\
(0.017)\end{array}$ & $\begin{array}{c}0.242 * * * \\
(0.016)\end{array}$ & $\begin{array}{c}0.298 * * * \\
(0.018)\end{array}$ & $\begin{array}{c}0.381 * * * \\
(0.021)\end{array}$ \\
\hline Return on Assets & $\begin{array}{l}-0.070 \\
(0.073)\end{array}$ & $\begin{array}{c}0.049 \\
(0.046)\end{array}$ & $\begin{array}{l}-0.042 \\
(0.047)\end{array}$ & $\begin{array}{r}-0.026 \\
(.051)\end{array}$ & $\begin{array}{l}-0.055 \\
(0.054)\end{array}$ & $\begin{array}{c}-0.082 * \\
(0.06)\end{array}$ \\
\hline Capital Intensity & $\begin{array}{c}-0.561 * * * \\
(0.137)\end{array}$ & $\begin{array}{c}-0.544 * * * \\
(0.137)\end{array}$ & $\begin{array}{c}-0.503 * * * \\
(0.142)\end{array}$ & $\begin{array}{c}-1.045^{* * *} \\
(0.164)\end{array}$ & $\begin{array}{c}-0.873 * * * \\
(0.163)\end{array}$ & $\begin{array}{c}-0.746^{* * *} \\
(0.165)\end{array}$ \\
\hline \multirow[t]{2}{*}{ Leverage } & $\begin{array}{c}0.027 \\
(0.108)\end{array}$ & $\begin{array}{c}0.639 * \\
(0.457)\end{array}$ & $\begin{array}{c}0.165^{*} \\
(0.103)\end{array}$ & $\begin{array}{c}0.168 \\
(0.221)\end{array}$ & $\begin{array}{c}0.127 \\
(0.118)\end{array}$ & $\begin{array}{c}0.124^{*} \\
(0.096)\end{array}$ \\
\hline & \multicolumn{6}{|c|}{ Industry Level Controls } \\
\hline Industry Dummies & Yes & Yes & Yes & Yes & Yes & Yes \\
\hline \% of Obs. Predicted & $71.26 \%$ & $68.30 \%$ & $71.91 \%$ & $70.54 \%$ & $73.12 \%$ & $74.20 \%$ \\
\hline Number of Observations & 7191 & 6757 & 6757 & 5815 & 5815 & 5815 \\
\hline
\end{tabular}


Table C6 - Replication of Leuz and Oberholzer-Gee (2006) Baseline Regression

This regression replicates Leuz and Oberholzer-Gee's (2006) baseline regression on the role of political connections as a determinant (or deterrent) in firms' decisions to cross-list in Indonesia. This should be viewed as complimentary to both the regression I run in Table 3 (Column 2) in the body of the paper because that regression is exactly the same; however, it is run on all countries with available data rather than being restricted to the Indonesian context. The only differences between my Indonesia regression and Leuz and OberholzerGee's are (i) the exact measure of political connections and (ii) the exact sample year for the regression. In Leuz and Oberholzer-Gee's Indonesia regression the coefficient on political connections is negative and statistically significant; in my Indonesia regression, it is negative but not statistically significant. The aforementioned differences may be why. Nevertheless, the results from this single country case are different than those found for the average case across countries as seen in Table 3 (Column 2) or Column 1 here because they do not adequately control for country-level factors.

TABLE C6 - Does being politically increase the probability of cross-listing? (All Countries, Indonesia Only)

\begin{tabular}{|c|c|c|}
\hline Dependent Variable: & \multicolumn{2}{|c|}{ Cross List Dummy } \\
\hline Sample: & All Countries & Indonesia Only \\
\hline \multirow[t]{3}{*}{ Politically Connected } & $0.583 * * *$ & -0.303 \\
\hline & $(0.123)$ & $(0.688)$ \\
\hline & \multicolumn{2}{|c|}{ Firm Level Controls } \\
\hline Size & -0.001 & $1.533 * * *$ \\
\hline & $(0.008)$ & $(0.304)$ \\
\hline \multirow[t]{2}{*}{ Return on Assets } & 0.043 & 1.682 \\
\hline & $(0.040)$ & $(3.069)$ \\
\hline \multirow[t]{2}{*}{ Capital Intensity } & $-0.473 * * *$ & -0.626 \\
\hline & $(0.153)$ & $(1.484)$ \\
\hline \multirow[t]{3}{*}{ Leverage } & 0.497 & -0.098 \\
\hline & $(0.380)$ & $(1.565)$ \\
\hline & \multicolumn{2}{|c|}{ Industry Level Controls } \\
\hline \multirow[t]{2}{*}{ Industry Dummies } & Yes & Yes \\
\hline & \multicolumn{2}{|c|}{ Country Level Controls } \\
\hline Country Dummies & No & $\mathrm{n} / \mathrm{a}$ \\
\hline Scenario being Tested: & \multicolumn{2}{|c|}{ Wald Tests (F-Statistics) } \\
\hline Joint Insig. of Industry Dummies & 41.336 & 4.827 \\
\hline Percent of Obs. Predicted Correctly & $64.15 \%$ & $83.81 \%$ \\
\hline Number of Observations & 7461 & 105 \\
\hline
\end{tabular}

*** represents statistical significance at the $1 \%$ level; ** at the $5 \%$ level and * at the $10 \%$ level. In parentheses below the estimated coefficient values are Huber/White robust standard errors. Column 1 shows the same results as in column 2 of Table 3 as a benchmark. Columns 2 shows Leuz and Oberholzer-Gee's (2006) baseline regression which was a single country study done in Indonesia only, replicated using my dataset which employs a slightly different measure of political connection. For the Wald tests, the null hypotheses is $\mathrm{H}_{0}: \gamma_{\mathrm{j}}=0$ for all $j$; the null for each of these are strongly rejected in all regressions, meaning that the including the dummy variables has joint significance at the $1 \%$ level. 
Table C7 - Firm-level controls interacted with politically connected firm dummy variable

Foreign financial markets could respond differently to the core characteristics of connected firms vis-à-vis unconnected firms; if this were true, then we might be concerned about it biasing my core findings. I can test for such biases by estimating: $\operatorname{Pr}\left[y_{i}=1\right]=\Lambda\left(\gamma_{i} X_{i}+\beta \cdot d_{-}\right.$connect $\left._{i} \cdot X_{i}+\sum_{\forall j} \gamma_{j} d_{j}+\sum_{\forall k} \gamma_{k} d_{k}+\varepsilon_{i j k}\right)$ where $d_{-}$connect $t_{i}$ represents my dummy variable for politically connected firms; $X_{i}$ represents the firm-level controls; $d_{j}$, industry dummies; and $d_{k}$, country dummies.

If $\beta$ is measurably different than zero, then we should be concerned that foreign capital markets respond differently to firms' core characteristics depending upon their political status. If $\beta$ is not measurably different than zero, concerns about how foreign capital markets may respond differently to firm-level characteristics should not adulterate the prior analysis. The results (in the Appendix) indicate that foreign financial markets do not respond differently to the core observable corporate financing characteristics of firms depending upon their political status.

TABLE C7 - Robustness Check: Interactions of Firm Level Variables with Connectedness

\begin{tabular}{|c|c|c|c|c|}
\hline Dependent Variable: & \multicolumn{4}{|c|}{ Cross List Dummy } \\
\hline \multirow[t]{3}{*}{ Politically Connected } & & $0.233^{\dagger}$ & -0.055 & \\
\hline & & $(0.157)$ & $(0.787)$ & \\
\hline & \multicolumn{4}{|c|}{ Firm Level Controls } \\
\hline Size & $0.721 * * *$ & $0.718 * * *$ & $0.719 * * *$ & $0.719 * * *$ \\
\hline & $(0.028)$ & $(0.028)$ & $(0.027)$ & $(0.027)$ \\
\hline \multirow[t]{2}{*}{ Return on Assets } & -0.267 & -0.265 & -0.256 & -0.256 \\
\hline & $(0.437)$ & $(0.433)$ & $(0.393)$ & $(0.394)$ \\
\hline \multirow[t]{2}{*}{ Capital Intensity } & $-0.670 * * *$ & $-0.660 * * *$ & $-0.632 * * *$ & $-0.631 * * *$ \\
\hline & $(0.182)$ & $(0.182)$ & $(0.188)$ & $(0.188)$ \\
\hline \multirow[t]{2}{*}{ Leverage } & -0.195 & -0.208 & -0.224 & -0.224 \\
\hline & $(0.252)$ & $(0.252)$ & $(0.267)$ & $(0.266)$ \\
\hline \multirow[t]{2}{*}{ Size * Connected } & & & 0.031 & 0.028 \\
\hline & & & $(0.052)$ & $(0.020)$ \\
\hline \multirow[t]{2}{*}{ Return on Assets * Connected } & & & -1.101 & -1.081 \\
\hline & & & $(1.400)$ & $(1.344)$ \\
\hline \multirow[t]{2}{*}{ Capital Intensity * Connected } & & & -0.397 & -0.404 \\
\hline & & & $(0.658)$ & $(0.641)$ \\
\hline \multirow[t]{3}{*}{ Leverage * Connected } & & & -0.031 & -0.024 \\
\hline & & & $(0.771)$ & $(0.762)$ \\
\hline & & Industry & Controls & \\
\hline \multirow[t]{2}{*}{ Industry Dummies } & Yes & Yes & Yes & Yes \\
\hline & \multicolumn{4}{|c|}{ Country Level Controls } \\
\hline Country Dummies & Yes & Yes & Yes & Yes \\
\hline Scenario being Tested: & \multicolumn{4}{|c|}{ Wald Tests (F-Statistics) } \\
\hline Joint Insig. of Ind. Dummies & 33.990 & 34.029 & 34.116 & 34.133 \\
\hline Joint Insig. of Country Dummies & 34.409 & 34.237 & 34.683 & 34.684 \\
\hline$\%$ of Obs. Predicted Correctly & $79.31 \%$ & $79.27 \%$ & $79.27 \%$ & $79.27 \%$ \\
\hline Number of Observations & 7461 & 7461 & 7461 & 7461 \\
\hline
\end{tabular}

*** represents statistical significance at the $1 \%$ level; $* *$ at the $5 \%$ level and $*$ at the $10 \%$ level; $\dagger$ indicates significant at the $15 \%$ level for the coefficient on the politically connected dummy variable only. The estimation method for all regressions is logit. In parentheses below the estimated coefficient values are Huber/White robust standard errors. For the two Wald tests shown, the null hypotheses are $H_{0}: \gamma_{j}=0$ for all $\mathbf{j}$ and $H_{0}: \gamma_{k}=0$ for all $k$; the null for each of these are strongly rejected in all regressions, meaning that the including the dummy variables has joint significance at the $1 \%$ level. For the regression in the final two columns terms including the political connections dummy variable are jointly significant at between the $10 \%$ and $15 \%$ level just as they are in Column 2. 


\section{Notes on Tables C8 and C9}

What happens if I re-estimate several of my baseline regressions on different samples of countries? Doing so improves the robustness of my results as the regressions' output changes in ways we should expect if my main hypotheses hold.

In Table W2, I re-run the regression testing the interaction between firm-level political connections and country-level property rights institution (originally found in Table 6, Column 1) on different samples. In Table W3, I re-estimate the regression testing the independent (noninteracted) effect of political connections on firms' cross-listing activity (originally found in Table 3, Column 1) on different samples.

\section{Eliminating Countries with Zero Connected Firms}

The logic for eliminating countries with zero observable political connections from the sample in my regressions is that there may be some 'under-coding' of political connections in these countries (i.e. there may be firms with either unobservable or alternative types of ties to their governments coded as zeros in my dataset instead of ones). We should expect any undercoding the political connection measure to be biased against my results.

Consequently, when we re-run regressions on a sample that drops countries where there are no firms coded as having political connections, we should expect: (1) the predictive ability of the regression may rise marginally; and (2) that the coefficient of interest remains relatively stable. Row 1, Column 2 in both Table W2 and Table W3 demonstrate that our expectations are in-line with the statistical reality.

These findings do not preclude the possibility, however, that there are other ways in which firms maintain political influence. The findings also do not imply that other varieties of political influence necessarily work through the property rights system. I discuss alternative possibilities more on in the sub-section on conceptualization.

Eliminating Countries with the Weakest Property Rights Institutions

The logic for eliminating countries in the quartile of firms with the weakest property rights institutions from the sample in my regressions is to get at outliers: maybe there is something different about these countries. Hypothesis 3, in fact, suggests that there is something different about how political connections work in weaker property rights countries; however, it does not go so far as to hypothesize what happens at the very extreme end of institutional weakness. 
If the general relationship predicted by Hypothesis 3 held, we would expect that when we drop the countries with the weakest property rights institutions from the sample that (1) we observe little change in the significance level of the coefficient of interest in the interacted regression and that (2) the coefficient value on a stand-alone political connections variable may shrink in magnitude. The reality shown in Row 1, Column 3 of both Table W2 and Table W3 is that (1) holds while (2) does not as the coefficient value actually increases marginally. These findings may be consistent with 'threshold effects' shown in Table 7 of the paper. I discuss potential reasons we see these 'threshold effects' further in the conceptualization section of the note.

\section{Eliminating Countries with the Highest Incidence of Politically Connected Firms}

The logic for eliminating countries in which there are especially high incidences of political connections is to get at outliers. The main problem with this approach is that even when I drop just the top 3 countries by incidence of political connections, I eliminate over $25 \%$ of the firms in my sample that exhibit the phenomena I am interested in studying. In fact dropping the

top 3 countries reduces the number of politically connected firms in the sample by 90 to just 265 out of a total sample of 7941 with complete data, making the phenomena I am interested in studying rarer than it is in reality. We should expect that results from the baseline regressions estimated on a sample truncated in this way are less likely to lead to significant results, as (1) there are fewer data points on the phenomena I want to study and (2) because that phenomena is hypothesized to be most relevant in the countries now dropped from the sample, which in turn should shrink the coefficient values on my variables of interest. Both (1) and (2) turn out to be true, explaining the results we see in Row 1, Column 4 of both Table W2 and Table W3. 


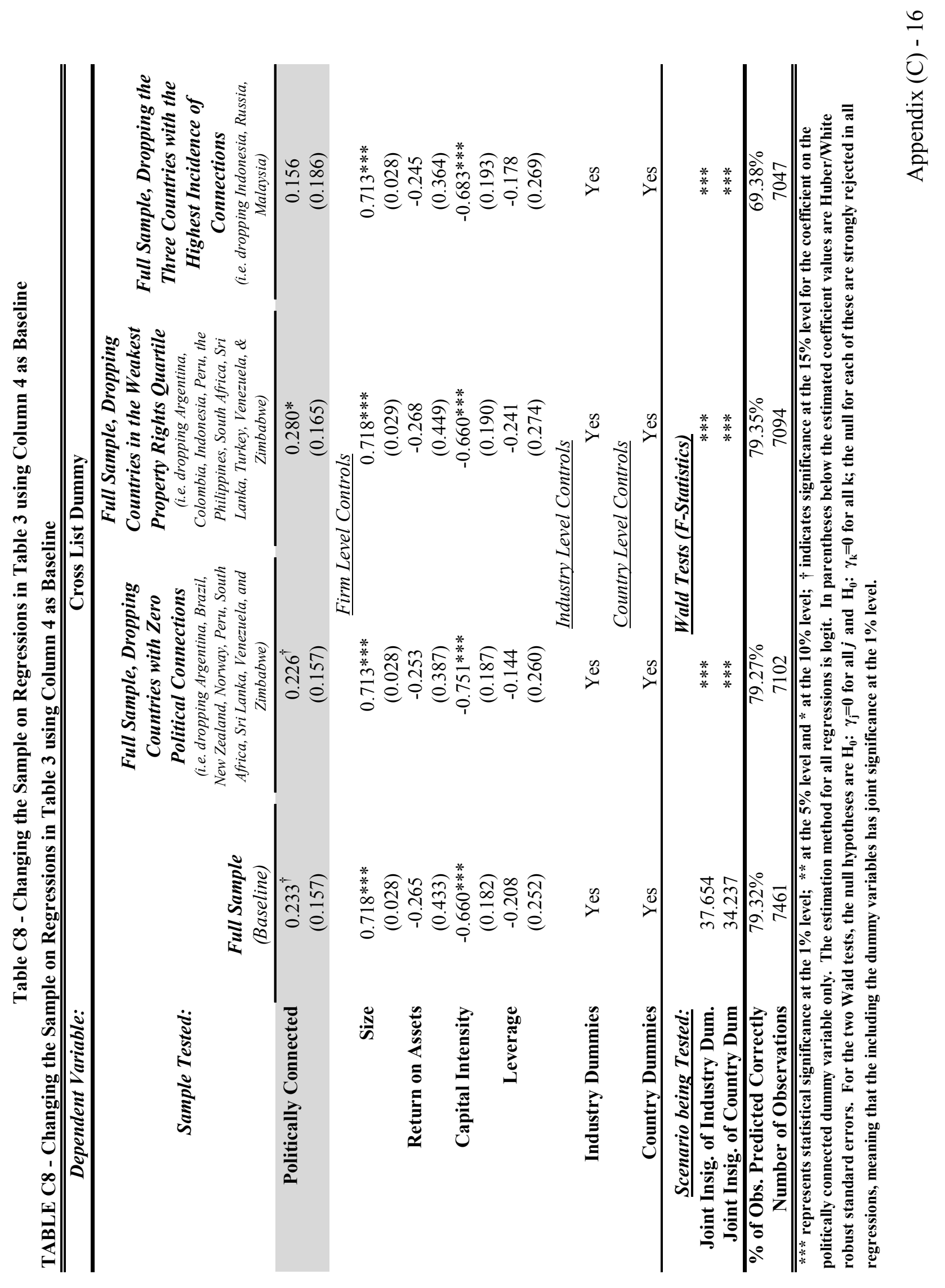




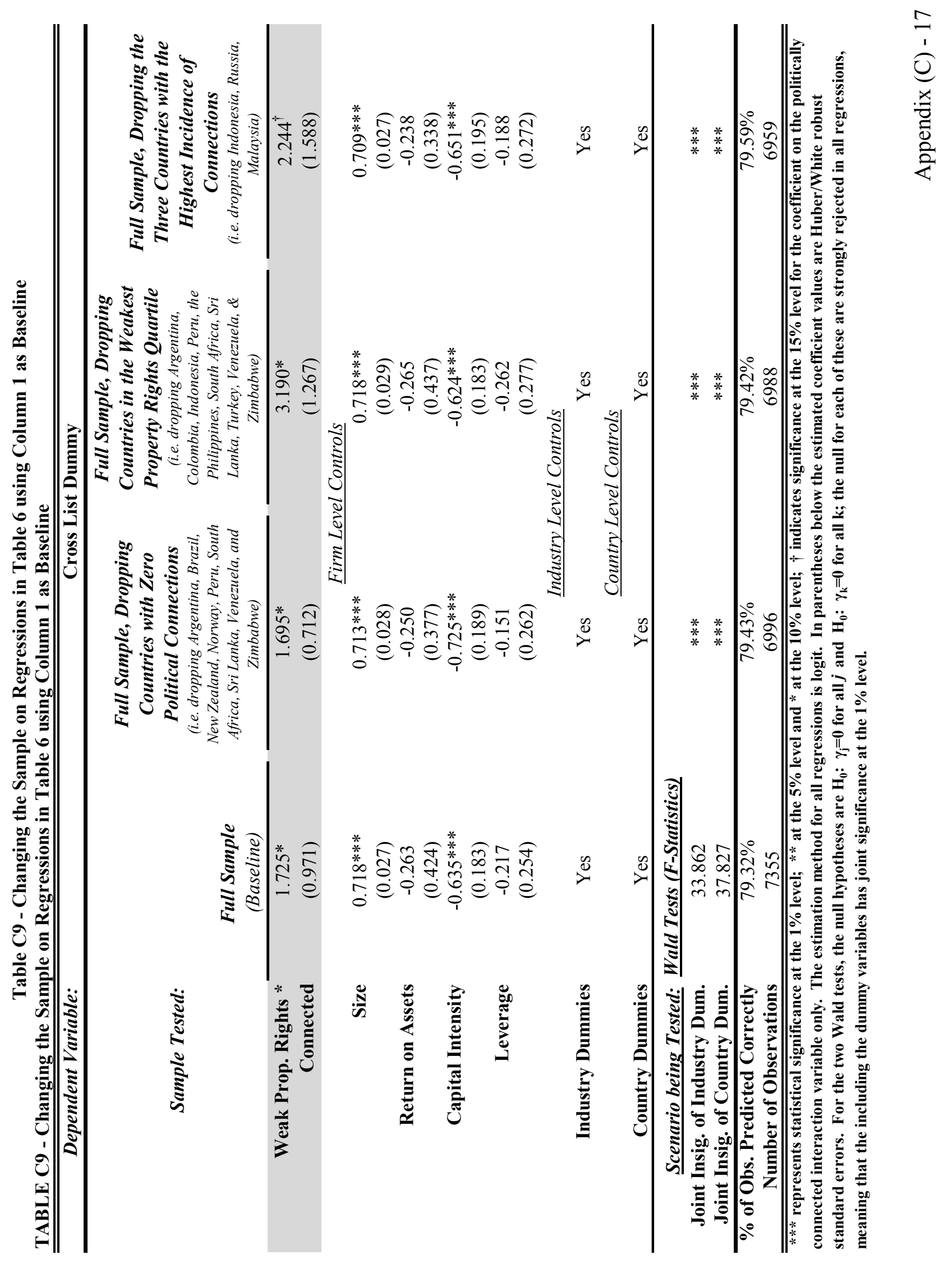


Table C10 - Testing the Interaction between Political Connection and 'Culture of Corruption'

What happens if we look at the interaction between politically connected firms and their home-country's culture of corruption, using Fisman and Miguel's (2007) data on unpaid diplomatic parking tickets in New York City as a measure? I explore this here; the results, in columns 2-5, show that the coefficient on this interaction is statistically insignificant and does not alter my primary result.

TABLE C10 - Testing the Interaction between Political Connection and 'Culture of Corruption'

\begin{tabular}{|c|c|c|c|c|c|}
\hline \multirow{3}{*}{$\begin{array}{c}\text { Dependent Variable: } \\
\text { Weak Property Rights * Connected }\end{array}$} & \multicolumn{5}{|c|}{ Cross List Dummy } \\
\hline & $1.725^{*}$ & & & 2.026 & 1.935 \\
\hline & $(0.971)$ & & & (1.499) & $(1.951)$ \\
\hline \multirow{3}{*}{$\begin{array}{r}\text { Diplomatic Parking Tickets * } \\
\text { Connected }\end{array}$} & & 0.014 & 0.007 & -0.006 & -0.005 \\
\hline & & $(0.012)$ & $(0.014)$ & $(0.018)$ & $(0.019)$ \\
\hline & \multicolumn{5}{|c|}{ Firm Level Controls } \\
\hline \multirow{2}{*}{\multicolumn{2}{|c|}{ Politically Connected }} & \multirow{2}{*}{\multicolumn{3}{|c|}{$\begin{array}{c}0.193 \\
(0.180)\end{array}$}} & 0.018 \\
\hline & & & & & $(0.231)$ \\
\hline \multirow[t]{2}{*}{ Size } & $0.718 * * *$ & $0.717 * * *$ & $0.715 * * *$ & $0.714 * * *$ & $0.714 * * *$ \\
\hline & $(0.027)$ & $(0.028)$ & $(0.028)$ & $(0.027)$ & $(0.028)$ \\
\hline \multirow[t]{2}{*}{ Return on Assets } & -0.263 & -0.260 & -0.258 & -0.255 & -0.255 \\
\hline & $(0.424)$ & $(0.415)$ & $(0.412)$ & $(0.399)$ & $(0.399)$ \\
\hline \multirow[t]{2}{*}{ Capital Intensity } & $-0.635 * * *$ & $-0.680 * * *$ & $-0.673 * * *$ & $-0.649 * * *$ & $-0.649 * * *$ \\
\hline & $(0.183)$ & 0.183 & -0.183 & $(0.184)$ & $(0.184)$ \\
\hline \multirow[t]{3}{*}{ Leverage } & -0.217 & -0.160 & -0.166 & -0.171 & -0.171 \\
\hline & $(0.254)$ & $(0.237)$ & $(0.237)$ & $(0.238)$ & $(0.238)$ \\
\hline & \multicolumn{5}{|c|}{ Industry Level Controls } \\
\hline \multirow[t]{2}{*}{ Industry Dummies } & Yes & Yes & Yes & Yes & Yes \\
\hline & \multicolumn{5}{|c|}{ Country Level Controls } \\
\hline Country Dummies & Yes & Yes & Yes & Yes & Yes \\
\hline Scenario being Tested: & \multicolumn{5}{|c|}{ Wald Tests (F-Statistics) } \\
\hline Joint Insig. of Industry Dummies & 33.862 & $* * *$ & $* * *$ & $* * *$ & $* * *$ \\
\hline Joint Insig. of Country Dummies & 37.827 & $* * *$ & $* * *$ & $* * *$ & $* * *$ \\
\hline$\%$ of Obs. Predicted Correctly & $79.32 \%$ & $78.38 \%$ & $78.32 \%$ & $79.34 \%$ & $79.32 \%$ \\
\hline Number of Observations & 7355 & 7021 & 7021 & 6921 & 6921 \\
\hline
\end{tabular}

*** represents statistical significance at the $1 \%$ level; ** at the $5 \%$ level and $*$ at the $10 \%$ level. $\$$ represents these coefficents are jointly significant at the $\mathbf{1 0 \%}$ level for the second column. The estimation method for all regressions is logit. In parentheses below the estimated coefficient values are Huber/White robust standard errors. For the Wald test, the null hypotheses is $\mathrm{H}_{0}: \gamma_{j}=0$ for all $j$ and $\mathrm{H}_{0}: \gamma_{k}=0$ for all $k$; the null for each of these are strongly rejected in all regressions, meaning that the including the dummy variables has joint significance at the $1 \%$ level. 